\title{
The Environmental, Social, and Economic Benefits of Blue Green Infrastructure in an Urbanized Area
}

Joseph L. Oguns

jlo0001@mix.wvu.edu

Follow this and additional works at: https://researchrepository.wvu.edu/etd

Part of the Agricultural and Resource Economics Commons, Environmental Design Commons, Environmental Studies Commons, Geographic Information Sciences Commons, Landscape Architecture Commons, Spatial Science Commons, and the Urban, Community and Regional Planning Commons

\section{Recommended Citation}

Oguns, Joseph L., "The Environmental, Social, and Economic Benefits of Blue Green Infrastructure in an Urbanized Area" (2019). Graduate Theses, Dissertations, and Problem Reports. 3765.

https://researchrepository.wvu.edu/etd/3765

This Thesis is protected by copyright and/or related rights. It has been brought to you by the The Research Repository @ WVU with permission from the rights-holder(s). You are free to use this Thesis in any way that is permitted by the copyright and related rights legislation that applies to your use. For other uses you must obtain permission from the rights-holder(s) directly, unless additional rights are indicated by a Creative Commons license in the record and/ or on the work itself. This Thesis has been accepted for inclusion in WVU Graduate Theses, Dissertations, and Problem Reports collection by an authorized administrator of The Research Repository @ WVU. For more information, please contact researchrepository@mail.wvu.edu. 


\title{
The Environmental, Social, and Economic Benefits of Blue
} Green Infrastructure in an Urbanized Area

\author{
Joseph L. Oguns \\ Thesis submitted to \\ Davis College of Agriculture, Natural Resources and Design \\ In partial fulfillment of the requirements for the degree of \\ Master of Landscape Architecture \\ In \\ Landscape Architecture Department \\ Davis College of Agriculture, Natural Resources and Design
}

Shan Jiang, Ph.D. Committee Chairperson.

Elisabeth Orr, MLA.

Charlie Yuill, MLA.

Michael Strager, Ph.D.

School of Design and Community Development, Division of Resource Management

Morgantown, West Virginia

2019

Keywords: Blue - Green Infrastructure; non-point source pollution; Co2 emission; air pollution; park; total suspended solids; watershed; surface water runoff; water quality; Pittsburgh

Copyright 2019 Joseph L. Oguns 


\section{Abstract}

\section{The Environmental, Social, and Economic Benefits of Blue Green Infrastructure in an Urbanized Area}

\section{Joseph L. Oguns}

At present, it is evident that there is a shift from rural to an urban settlement which results in high demand for residential buildings and other urban infrastructure. Blue - Green Infrastructure (BGI) is a system of using blue (water) and green (nature) to address urban and environmental challenges. The purpose of this study is to evaluate the environmental, social, and economic benefits of blue-green infrastructure in an urbanized area in Pittsburgh, Pennsylvania, USA. The study involves the utilization of Geographic Information System (GIS) to determine water quality level resulting from nonpoint source pollution through acquiring elevation data; watershed; and processing the elevation data through performing appropriate watershed delineation for the study area. Different landscape models (i-Tree Design, i-Tree Landscape) were explored to determine the different benefits attached to BGI Infrastructure aside aesthetic and refuge benefits from the Landscape Performance Series database. The i-Tree Landscape gives one an idea of areas where particulate matter and atmospheric gases exist, and areas to prioritize planting of trees. A pilot scale-site was chosen from the discovered areas to prioritize plantation with the help of some selected criteria. Five design patterns (Green Parks, Riverfront, Activity Nodes, Green Parking, and Green Streets) were adapted, an i-Tree Design model was used to get the pre and post environmental and economic benefits of trees on a 10-yr. expectation plan. The water quality model, I discovered areas that have high total suspended solids (TSS) level giving one an idea on the water quality of the area. The areas pointed out as areas to prioritize planting by the i- Tree Landscape model also has high TSS level from the GIS delineation to further justify the outcomes of the two models used. Sustainable design concepts were provided on how to practice/ incorporate blue-green infrastructure in areas that need interventions towards creating a balance between the built and natural environment. 


\section{Dedication}

I wish to dedicate this thesis project to my late father and to every committed youth. 


\section{Acknowledgement}

All achievements in life is a function of great ideas, lessons, theories, gifts, knowledge and talents of individuals who have in one way or the other added value to one's life, this thesis is not an exemption.

My unreserved gratitude goes to my committee chairperson Prof. Shan Jiang for being a good coach. Your advice, constructive feedbacks, and guide has been instrumental towards the success of this thesis project. Thank you for believing in me.

My gratitude also goes to Prof. Lisa Orr my first boss in the department, I enjoyed working with you and gained wealth of experience as your Graduate Research Assistant. Thank you so much for your input in this project; I sincerely appreciate your guide, and support.

I will like to extend my thanks to Prof. Charlie Yuill for your guide in the just concluded urban design class and for your tremendous inputs in this thesis. Thank you for being there.

I express my deepest thanks to Prof. Michael Strager for inspiring me towards gaining a Graduate Certificate in GIS and Spatial Analysis which has played a good role in the execution of parts of this thesis project. Thank your advice, and constructive feedbacks in all forms towards making this thesis project a success.

My gratitude goes to my lovely wife, my parents, my brothers and sister, colleagues for their prayers and all forms of supports.

Lastly, my profound gratitude goes to God for giving me the life, wisdom, and strength to make my studies in MLA a success. 


\section{Table of Contents}

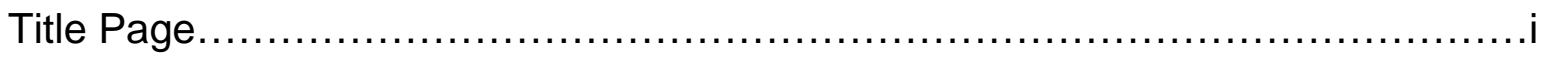

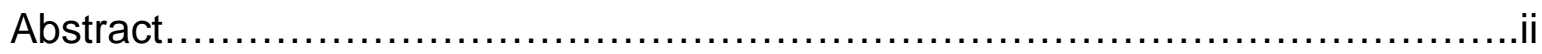

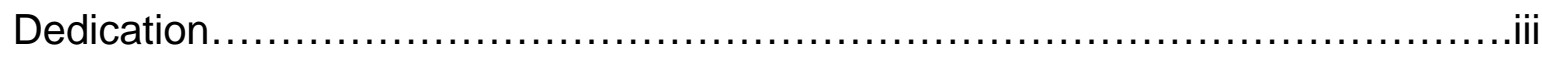

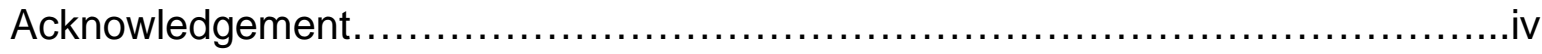

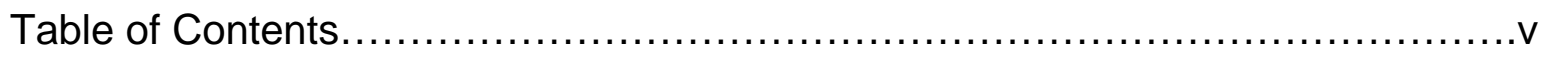

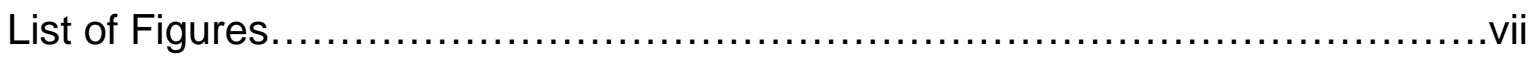

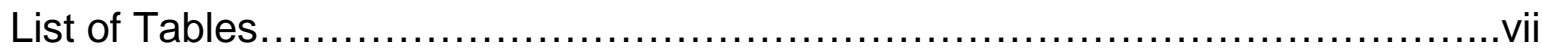

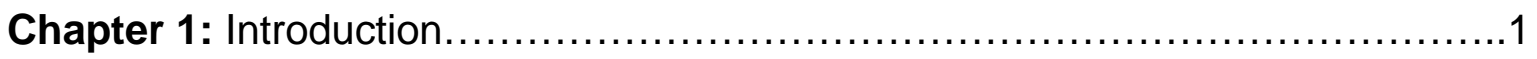

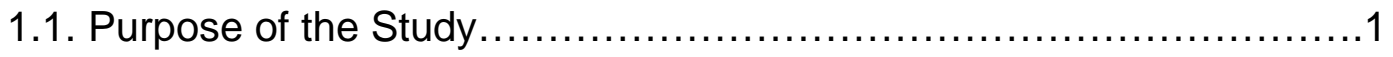

1.2. Research Question..................................... 2

1.3. Scope of the Study Area $\ldots \ldots \ldots \ldots \ldots \ldots \ldots \ldots \ldots \ldots \ldots \ldots \ldots \ldots \ldots \ldots \ldots \ldots, 2$

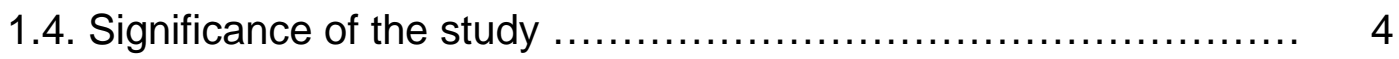

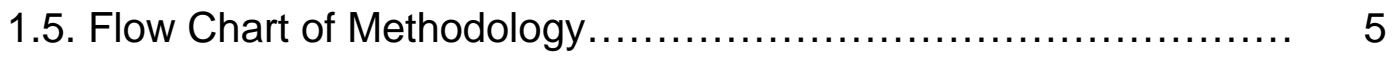

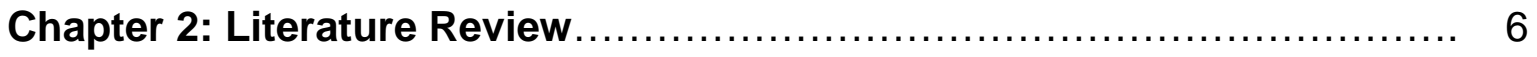

2.1. History of Green Blue Infrastructure $\ldots \ldots \ldots \ldots \ldots \ldots \ldots \ldots \ldots \ldots, 6$

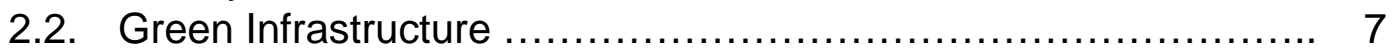

2.3. The role of Green Infrastructure on Health...... 7

2.4. The role of Green Infrastructure on Social Bond................ 8

2.5. The Role of Green Infrastructure on Air Quality $\ldots \ldots \ldots \ldots \ldots \ldots \ldots$

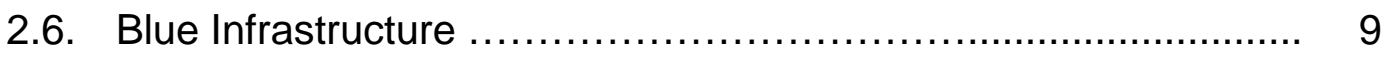

2.7. The Role of Blue Infrastructure on Wellness $\ldots \ldots \ldots \ldots \ldots \ldots \ldots \ldots . \ldots$

2.8. The Role of Blue Infrastructure on Economy ....................... 10

2.9. Nonpoint Source Pollution.................................. 10

2.10. Economic Benefits of Improving on Water Quality $\ldots \ldots \ldots \ldots \ldots \ldots \ldots 11$

2.11. How Green Blue Infrastructure can be executed ................. 11 
Chapter 3: Research Methods.

3.1. Data Sources and Processing ................................. 14

3.2. Water Quality Processing .................................... 19

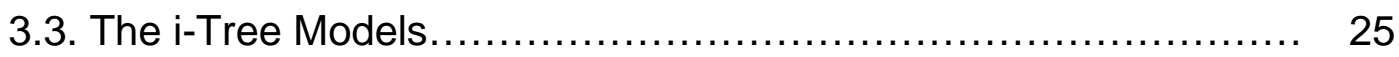

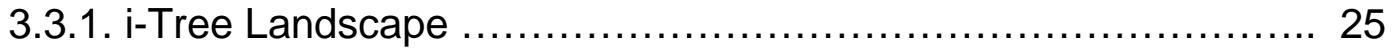

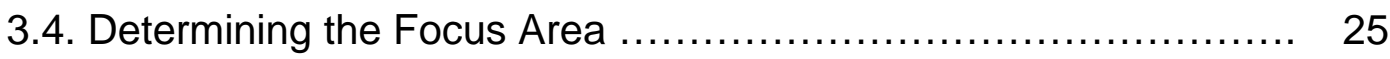

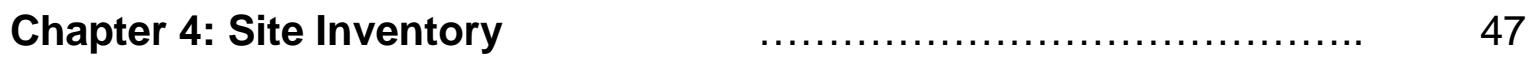

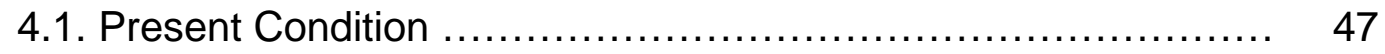

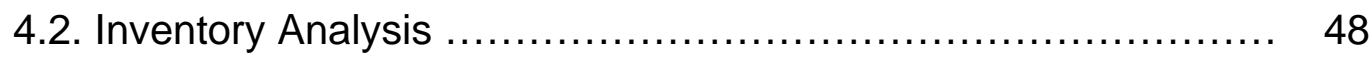

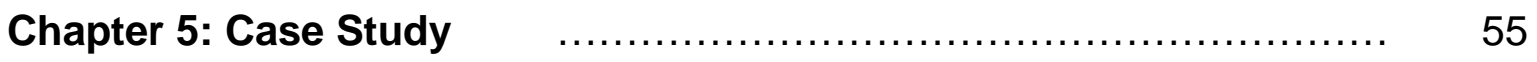

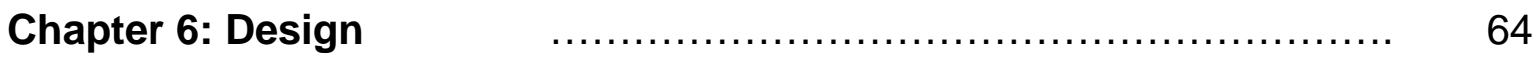

Perspective / Sectional Views................................... $\quad 77$

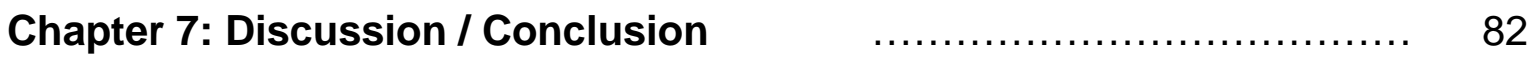

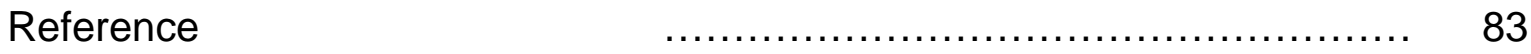




\section{List of Figures}

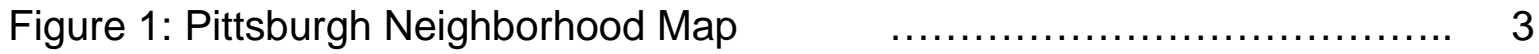

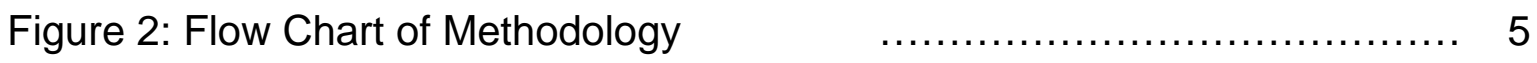

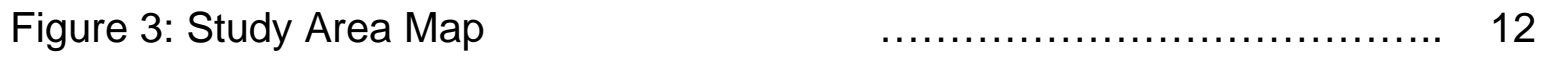

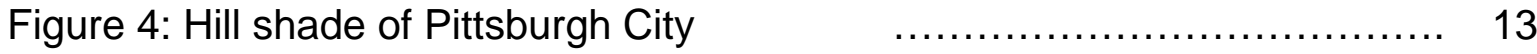

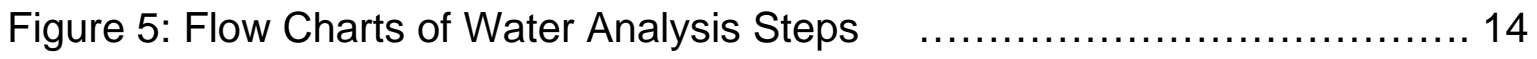

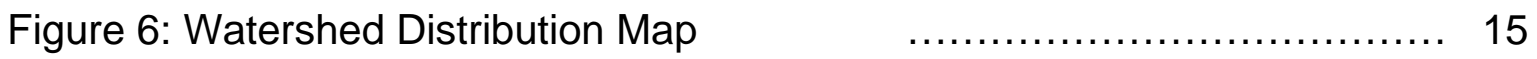

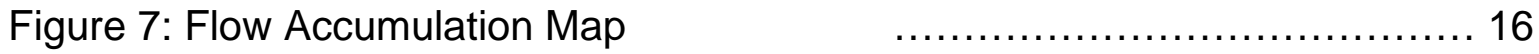

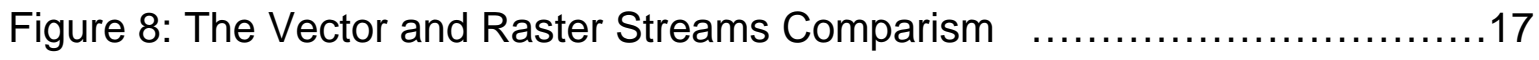

Figure 9: Thin, Streamgrid, and Watergrid Result Map $\quad \ldots \ldots \ldots \ldots \ldots \ldots \ldots \ldots \ldots \ldots$

Figure 10: Expected Mean Concentration Map $\quad$........................ 20

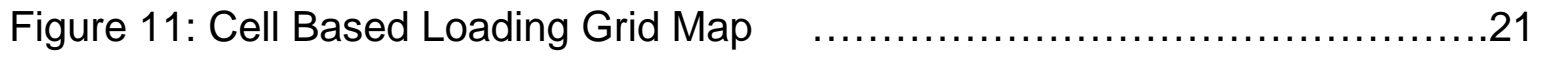

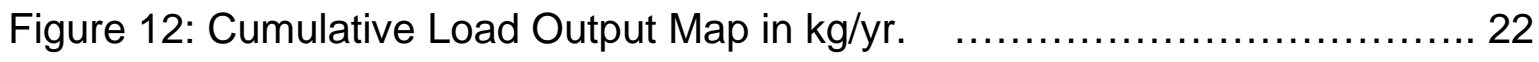

Figure 13: Cumulative Load Output Map in kg/yr. with Base Map ............... 23

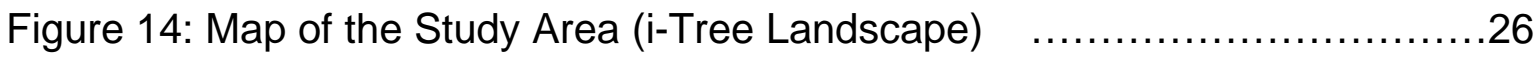

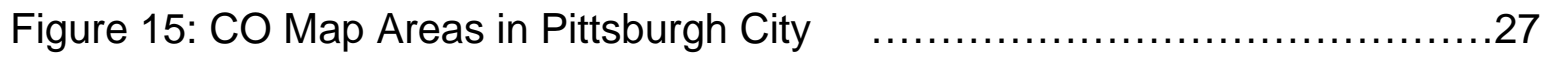

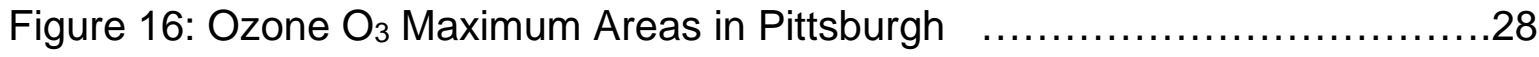

Figure 17: Particulate Matter 2.5 Average Areas in Pittsburgh $\ldots \ldots \ldots \ldots \ldots \ldots \ldots . \ldots 29$

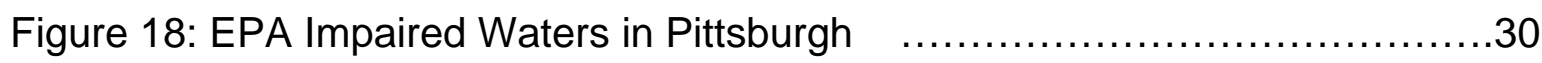

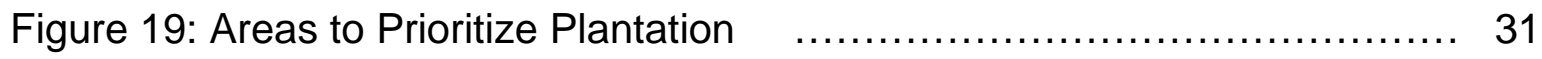

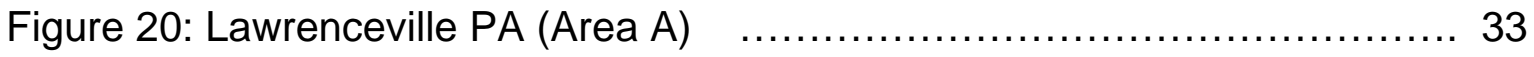

Figure 21: Areas to Prioritize Plantation in North Oakland $\ldots \ldots \ldots \ldots \ldots \ldots \ldots \ldots . \ldots . \ldots . \ldots . \ldots . \ldots$

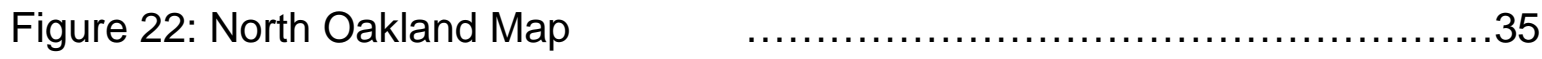

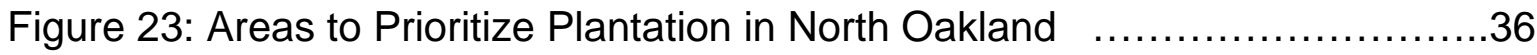


Figure 24-33: Present Condition of the Site (Google Images) $\ldots \ldots \ldots \ldots \ldots \ldots \ldots 47$

Figure 34: Flood Map of Upper Lawrenceville, PA $\ldots \ldots \ldots \ldots \ldots \ldots \ldots \ldots \ldots \ldots \ldots$

Figure 35: Figure Ground of Upper Lawrenceville, PA $\ldots \ldots \ldots \ldots \ldots \ldots \ldots \ldots \ldots \ldots$

Figure 36: Topography of Upper Lawrenceville, PA $\ldots \ldots \ldots \ldots \ldots \ldots \ldots \ldots \ldots \ldots \ldots 1$

Figure 37: Soil Mapping of Upper Lawrenceville, PA $\ldots \ldots \ldots \ldots \ldots \ldots \ldots \ldots \ldots \ldots \ldots 2$

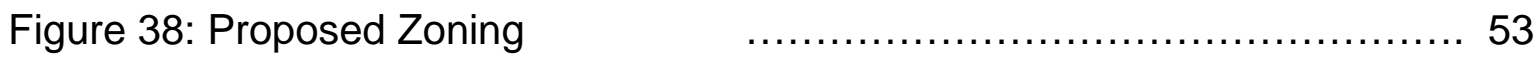

Figure 39 - 46: Smartinski Park Playground, Slovenia $\quad \ldots \ldots \ldots \ldots \ldots \ldots \ldots \ldots \ldots . \ldots$

Figure 47 - 52: Tom Hanafan River's Edge Park, Phase I, lowa $\quad \ldots \ldots \ldots \ldots . . .58$

Figure 53 - 58: Garden of Seven Moments, Switzerland $\quad \ldots \ldots \ldots \ldots \ldots \ldots \ldots \ldots \ldots \ldots$

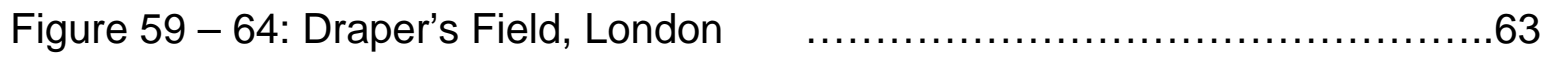

Figure 65: Composite Analysis Map of Upper Lawrenceville, PA ............ 64

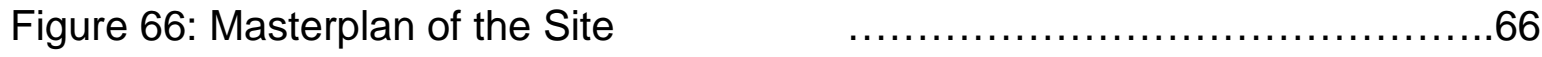

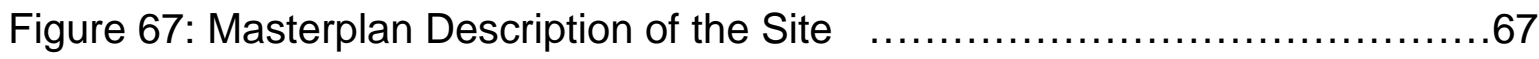

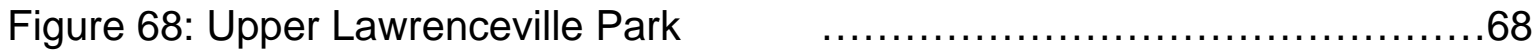

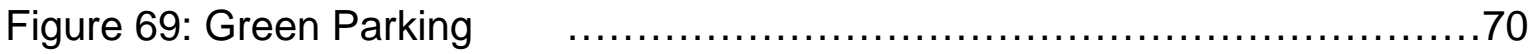

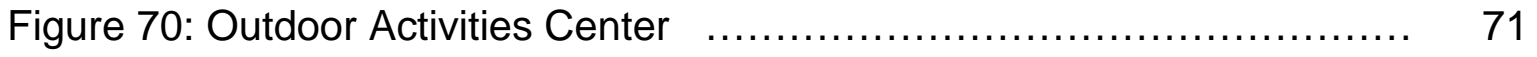

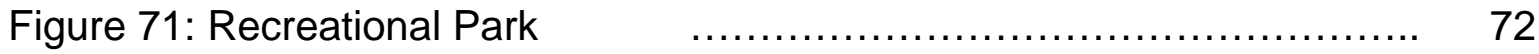

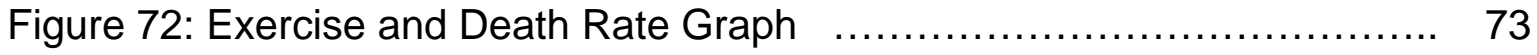

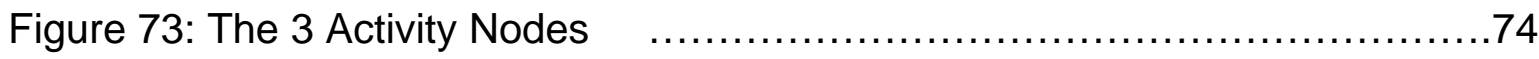

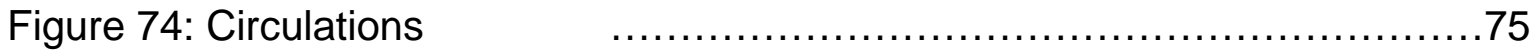

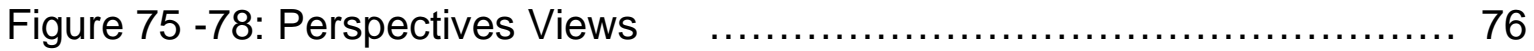

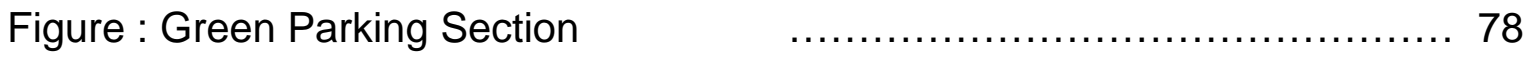

Figure: The Recreational Park Section $\quad$ …........................

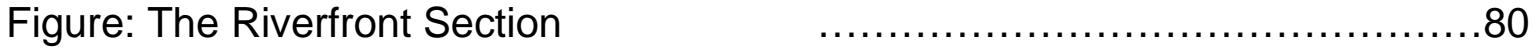


Figure: Upper Lawrenceville Park Section 


\section{List of Tables}

Table 1: Total Suspended Solids (TSS) Values Versus NLCD $2011 \quad \ldots \ldots \ldots \ldots 19$

Table 2: Canopy, Impervious, and Plantable Spaces Table $\quad \ldots \ldots \ldots \ldots \ldots 26$

Table 3: Carbon and $\mathrm{CO}_{2}$ Storage and Sequestration of Pittsburgh City $\quad \ldots \ldots \quad 26$

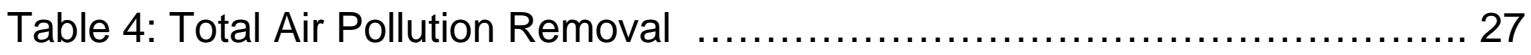

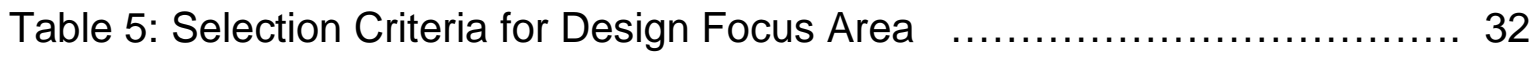

Table 6: Canopy, Impervious, and Plantable Spaces for Lawrenceville ...........33

Table 7: Carbon and $\mathrm{CO}_{2}$ Storage and Sequestration for Lawrenceville ...........33

Table 8: Canopy, Impervious, and Plantable Spaces for North Oakland ........ 35

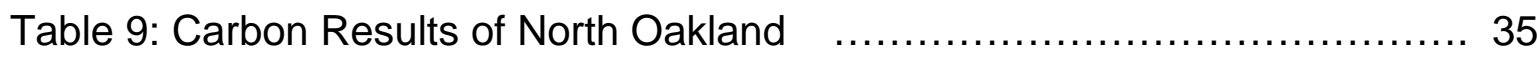

Table 10: Pre-Condition Results of Upper Lawrenceville Park Site ................38

Table 11: 10-Year Post Benefits Results of Upper Lawrenceville Park ............38

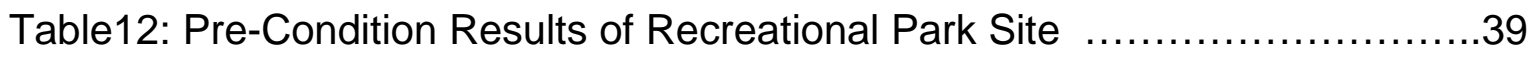

Table 13: 10-Year Post Benefits Results of Recreational Park Site .............. 39

Table 14: Pre-Condition Results of Outdoor Event Center $\ldots \ldots \ldots \ldots \ldots \ldots \ldots \ldots . \ldots . \ldots \ldots$

Table 15: 10-Year Post Benefits Results of the Outdoor Event Center ........... 40

Table 16: Pre-Condition Results of the 3 Activity Nodes $\quad \ldots \ldots \ldots \ldots \ldots \ldots \ldots \ldots \ldots \ldots$

Table 17: 10-Year Post Benefits Results of 3 Activity Nodes $\ldots \ldots \ldots \ldots \ldots \ldots \ldots . . \ldots 1$

Table 18: Pre-Condition Results of Green Parking ............................42

Table 19: 10-Year Post Benefits Results of Green Parking $\ldots \ldots \ldots \ldots \ldots \ldots \ldots \ldots . \ldots . \ldots . \ldots . \ldots$

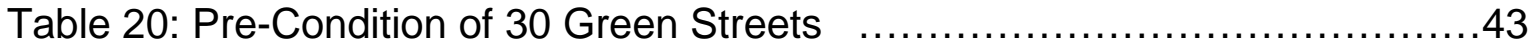

Table 21: 10-Year Post Benefits Results of 30 Green Streets .....................43

Table 22: Pre-Condition Results of the Riverfront $\ldots \ldots \ldots \ldots \ldots \ldots \ldots \ldots \ldots \ldots \ldots \ldots$

Table 23: 10-Year Post Benefits Results of the Riverfront ..................... 44 
Table 24: Pre-Condition Table of the 5 Design Patterns $\ldots \ldots \ldots \ldots \ldots \ldots \ldots \ldots \ldots . . \ldots \ldots$

Table 25: Post-Condition Table of the 5 Design Patterns $\quad \ldots \ldots \ldots \ldots \ldots \ldots \ldots \ldots \ldots$ 


\section{CHAPTER 1}

\section{Introduction}

\subsection{General Background for the Study}

The World Health Organization forecasted that there will be a $60 \%$ increase of the world's population of people that will be living in an urban settlement in 2030 and a possible increase of about $70 \%$ by 2050 (WHO, 2014). Such a move can lead to urban sprawl, which will affect human health because it will lead to loss of green and nature (Bell et al., 2010). Because of human activities (use of fertilizers on farms, transportation facilities, impervious surfaces, oil spills, buildings) there tend to be environmental, social, and climatic challenges in the urban areas which need to be attended to by her residents and the government, and it can be achieved through the continuous dissemination of research findings to stakeholders. Nonpoint pollution source (NPS) is the major cause of water pollution in the US (EPA, 2007). Discharges from NPS go into surfaces and ground waters in a diffuse manner. Before pollutants reach surface water or infiltrate into groundwater, it moves over an extensive land area. Land and runoff management practices are the best ways to reduce NPS pollution rather than focusing on effluent treatment.

\subsection{Purpose of the Study}

The purpose of this study is to evaluate the environmental, social and economic benefits of blue (water) - green (nature) infrastructure in an urbanized area in Pittsburgh, PA a postindustrial city. This study includes the use of Geographic Information System (GIS) to determine the water quality from the watershed and processing of the digital elevation model of the area using GIS tools, to use other landscape models (i-Tree Design, i-Tree Landscape) from Landscape Performance Series database to further determine environmental activities which affect air, water, land, and health. The various spatial tools that will be used in this project will help one to determine the best area to prioritize blue green infrastructure, and other benefits (social and economic), which one can derive from blue green infrastructures that are beyond aesthetic and shade from the canopies which are the quick benefits to think about. Sustainable Design concept particularly on the area 
that need to prioritize blue -green infrastructure from the i-Tree Landscape result was provided.

\subsection{Research Questions}

How to set up a process in determining where to prioritize blue green infrastructure in an urbanized area?

What are the environmental, social, and economic benefits of blue green infrastructures?

How can blue green Infrastructure improve urban sustainability and public health?

\subsection{Scope of the Study Area}

The study area is in Pittsburgh City, with a population of 305,704 residents within the city boundary (2017) it is the $63^{\text {rd }}$ - largest city in the US. Categorized as a postindustrial city. It is known as the "Steel City" with about 300 steel-based businesses and as the "City of Bridges". After World War II, the city launched a project known as "Renaissance" cleaning up the air and rivers and a focus on cultural and neighborhood development during "Renaissance II". The city is now the center of Leadership in Energy and Environmental Design. Pittsburgh is the county seat of Allegheny County, in southwest PA; which has a population of about 1,225,365 (Census 2010). It is categorized as the second largest county in the state with a total of 745 sq. mi $\left(1939 \mathrm{~km}^{2}\right)$. The elevation ranges from 208.3 $\mathrm{m}$ to $424.82 \mathrm{~m}$. 


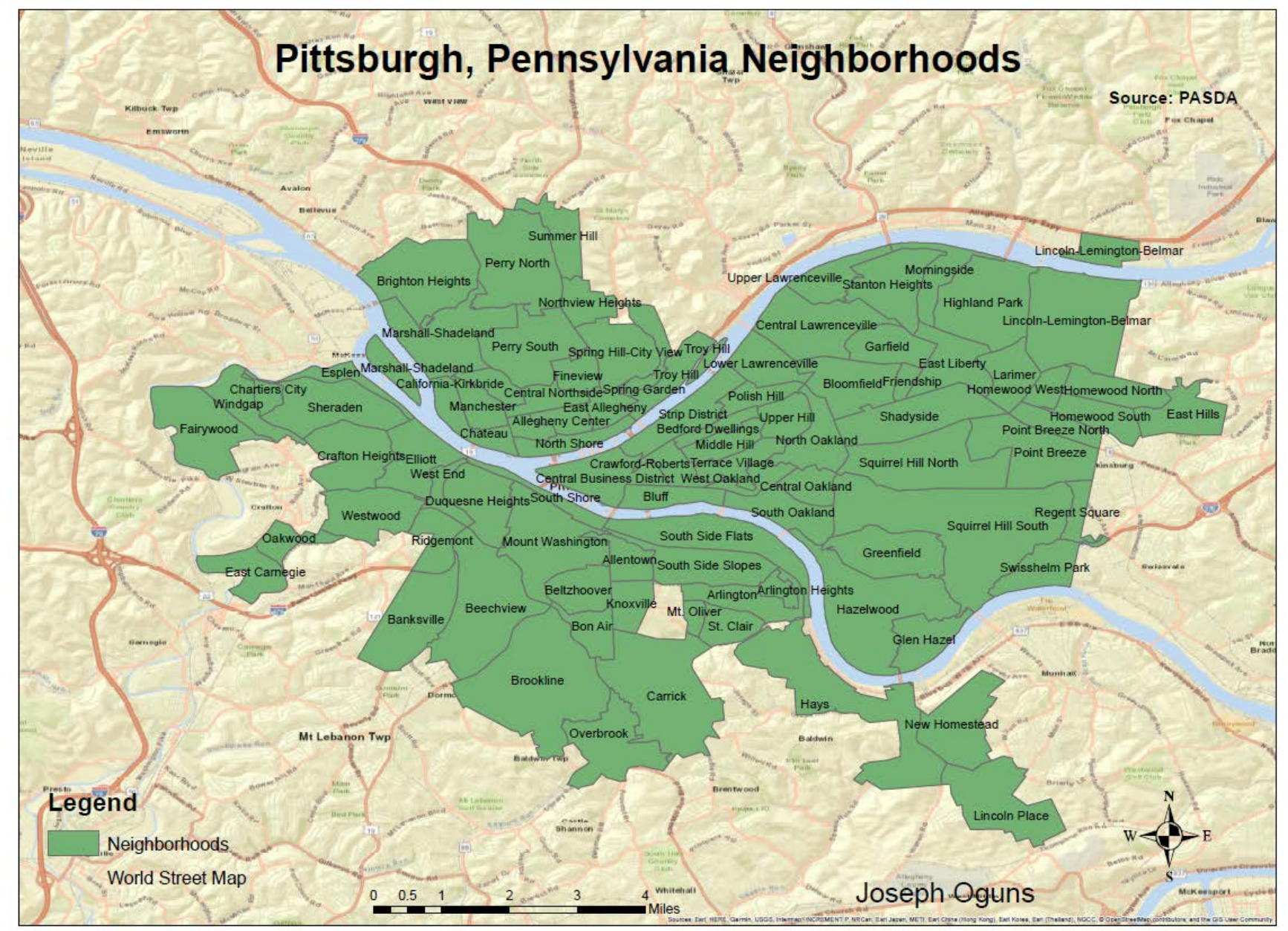

Figure 1: Pittsburgh Neighborhood Map

\subsection{Significance of the Study}

Green Infrastructure has a significant importance in enabling the social life of neighborhoods and creating a sense of community (Kim and Kaplan, 2004). There is a positive link between social life and health (Nieminen et al., 2010). People living in a region with high a percentage of green infrastructure have the tendency of lowering levels of stress (Grahn and Stigsdotter, 2003; Ward Thompson et al., 2012). Research has shown a reduction in risk of mortality from cardio - respiratory disease in urban areas having access to natural environment by 5 to 10 percent to areas with poor access (Mitchell and Pophan, 2008; Richardson and Mitchell, 2010). Water is an important part of the landscape in therapeutic landscape (Williams, 2010, p. 19637). Water is a symbol of purity being expressed in the mental and spiritual life of man. Non-point source pollution 
is a major cause of water quality degradation in America which makes it challenging to meet water quality standards for lakes, rivers, streams, and estuaries, most Appalachian states utilizes surface water for drinking and other purposes.

This study will help to guide the government and residents of areas at health risk because of the water quality level, determine the water quality of the areas to know areas at risk and take positive steps, also determining areas with $\mathrm{SO}_{2}, \mathrm{O}_{3}$, and $\mathrm{CO}$ presence in the air, it will help to determine areas to prioritize planting of trees and blue infrastructure, total area of impervious surfaces, the rate at which carbon storage/sequestration can be achieved with green infrastructure. The approach can be applied to any State in the United states or other countries with access to similar data. 


\subsection{Methodology}

Flow chart of Methodology
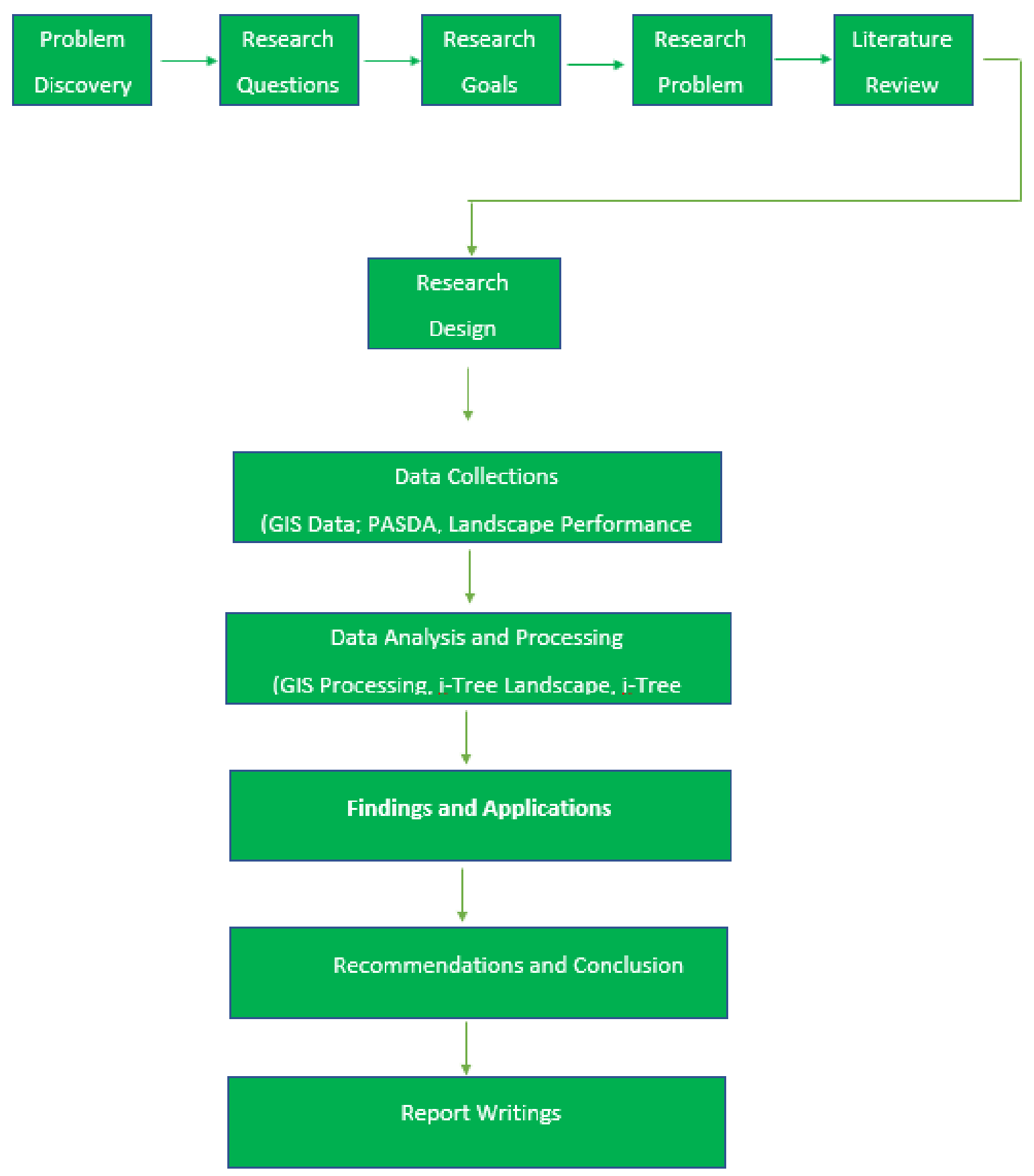

Figure 2: Flow Chart of Methodology 


\section{CHAPTER 2}

\section{Literature Review}

\subsection{History of Green Blue Infrastructure}

There is less concentration on sustainability, green blue infrastructure projects in the urban context, rather other areas of development were concentrated on; economic and consumerist expansion took over urban life which led to the subsidence of the urban system, resulting in massive setbacks in many cities. The quest for making cities more resilient, livable dynamic to a monofunctional lifeless system began (Dreiseitl, 2012). To make the city an engaging one by creating places for children to play and socializing among families and groups. Projects on the use of rainwater making, to be visualized and not hidden under the ground were employed; buffering of the rainwater after cloud bursts, cleaning of runoff from the road, feeding of the nearby streams and not polluting them. These projects were done at a different scale from the one done in the villages in Switzerland to larger scale projects in Berlin's

Potsdamer Platz (urban hydrology project); Bishan - Ang Mo Kio Park (blue-green and social infrastructure project) and Kallang Riverfront (rain and stormwater management project) in Singapore.

The World Health Organization forecasts that there will be a $60 \%$ increase of the world's population of people that will be living in an urban settlement in 2030 and a possible increase of about $70 \%$ by 2050 (WHO, 2014). Such a move can lead to urban sprawl, which will affect human health because it will lead to a loss of green space and nature (Bell et al., 2010).

Historically, from the mid-nineteenth century, the industrial growth and the migration of people into large cities in American Northeast and Midwest led to a reform in the urban landscape. 


\subsection{Green Infrastructure}

Green Infrastructure $(\mathrm{Gl})$ can be trailed to the nineteenth century (Benedict and Mc Mahon,2002). The sudden growth in urban areas affected many areas due to anthropogenic activities; poor sewer system; water contamination; pollution, communicable diseases; poor living conditions and the breakdown of physical infrastructures. These challenges brought about the advocacy of public parks in Europe called Birkenhead Park (Liverpool) and Victoria Park in the East End of London in the 1830 s and 1840s to boost the health of workers in the urban settlements (Ward Thompson, 2011). It helped to bring a change in North America, Frederick Law Olmstead when appointed as general of the sanitary commission in Riverside, Chicago, he utilized the public health facility (Szczygiel and Hewilt, 2000). He came out with his theories and plan on health, well- being and nature. It was discovered that mental, social and physical health risk is affected by industrialized urban settlement (Eisenman, 2013). Olmstead contributed to practical planning of natural system for health benefits using green infrastructure in the planning and development of cities. He further advocated for the provision of physical exercise in Buffalo Park (Taylor, 1999). He created a balance between users (health, recreation, and social bond) and nature (ecological function).

Patrick Geddes (1915) a biologist and a city planner, and lan McHarg (1971) looked at green infrastructure and sustainability in city development through nature connecting with people and place and creating a connection between human habitats and nature respectively (Hough, 2007 p54).

\subsection{The role of Green Infrastructure on Health}

The term 'health' is defined by WHO as the complete state of physical, mental, and social wellbeing and not only the absence of illness (WHO, 1948). There is a large body of research done in health and the environment in the past that studied on the negative side of the environment as it relates to public health including water-borne diseases, harmful chemicals that cause cancer and other illnesses (Frumkin, 2001). Recently, the focus has changed researchers now study on the positive sides of human health on different areas of physical and social environment, focusing on air quality, public transportation, urban and rural settlement, and green space. People's access to green infrastructure, housing, 
health, and education are categorized as the requirement for an excellent quality of life (CABE, 2010). Research has shown a reduction in risk of mortality from cardiorespiratory disease in urban areas having access to the natural environment by 5 to 10 percent to areas with poor access (Mitchell and Pophan, 2008; Richardson and Mitchell, 2010).

Four proposed health benefits of accessing nature were outlined (Hartig et al., 2014); Physical activity restorative value of nature; Social bond, and air quality improvement through green infrastructure.

Physical activity has both curative and preventive effects (Ward, Thompson, 2011). Lack of observance of physical activity has cost the UK economy more than $£ 5$ to $£ 8$ billion a year (Bird, 2007). Blood pressure can be reduced by access to the walkable green corridor (Orsega - Smith et al., 2004). Walking in a forest can as well assist cardiovascular relaxation and decreases bad physiological symptoms (Lee et al., 2014). Adults and children with more access to parks are prone to have a lower Body Mass Index (BMI) level (Wolch et al., 2011).

There is a lot of evidence on mental health advantages related to nature and green space. Exposure to nature can be curative (Hartig et al., 1991). People living in a region with green infrastructure have the tendency of lowering levels of stress (Grahn and Stigsdotter, 2003; Ward Thompson et al., 2012). More so, people having more than $1 \mathrm{~km}$ away from green infrastructure are tending to have higher levels of stress to those living close (Stigsdotter et al., 2010). The quality of a park is mostly studied recently and has more advantages on mental health to the number of public open spaces in the neighborhood (Francis et al., 2012). Residence with trees and grass that can be seen from the apartment buildings reduces mental stress and aggression level in comparison with the apartment where trees and grasses are not seen (Kuo and Sullivan, 2001). Overgrown or unmanaged green spaces is possible to increase the level of anxiety due to fear of crime (Kuo et al., 1998).

\subsection{The role of Green Infrastructure on Social Bond}

Green Infrastructure has significant importance in enabling the social life of neighborhoods and creating a sense of community (Kim and Kaplan, 2004). There is a 
positive relationship between social life and health (Nieminen et al., 2010), also with green infrastructure availability and health (De Vries et al., 2013). The urban green infrastructure in Switzerland helped in creating a social network among friends: children and young people from different demography (Seeland et al., 2009).

\subsection{The role of Green Infrastructure on Air Quality}

Regardless of the allergies gotten from the release of pollen, they also have positive effects. Air pollutants (particulate matter and gases) can be improved with trees and vegetation to enhance urban air quality (Nowak et al., 2006). Trees can be used as a refuge during summer to guide against excess heat and reduce the demand for air conditioning and relieves heat stress (Lafortezza et al., 2009).

\subsection{Blue Infrastructure}

Blue (water) Infrastructure is a unique element in a landscape that beautifies the environment. Several corporate developments depend on water (Kaplan and Kaplan, 1989). People are attracted to an environment that has water (lakes, coasts, rivers) (Nasar and Li, 2004).

\subsection{The Role of Blue Infrastructure on Wellness}

Water is an important part of the landscape in a therapeutic landscape (Williams, 2010, p. 19637). Holy walls of Ireland are sites of indigenous health (Foley, 2011, p. 477). Likewise, Lourdes Spring in South France is a healing center (Gesler, 1996, p. 101). It is seen as a serene and relaxing place (Ulrich, 1993). On the other hand, because of flooding, which is a potential hazard which can have a negative mental effect (Mell, 2008). Green and blue infrastructure have links that contribute positively to human health. Current studies have shown the restorative benefits to it (White et al., 2010; Volker and Kistemann, 2011, 2013). Blue spaces and coastal regions were seen to be more restorative to green nature scenes (White et al., 2013). The sense of place is key to well being of people. Water is seen as a natural mirror, displaying blurring images that are not as visible as normal mirror (Burmil et al., 1999, p. 101; Nasar and Li, 2004, p. 236). Water is seen as a symbol of purity which is being expressed in the mental and spiritual life of man. The idea behind seeing water as a holy thing is found in religious places like Lourdes 
in France (Nouwen, 1990, p. 8, cited by Gesler, 1996, p. 100), and at St. Anne de Beaupre in Quebec, Canada were people where people use water for healing, fertility and miraculous powers (Williams, 2010, p. 1637). Water is seen to have more influence on emotional well - being compared to other environments (Felsten, 2009, p. 166; Ulrich, 1981, p. 548).

\subsection{The Role of Blue Infrastructure on Economy}

Non-governmental business owners find it appealing to have businesses in blue spaces (Luttik, 2000). Benches for short relaxation and personal safety for bathing activities help support recreation activities (Asakawa et al., 2004 p. 177; Burmil et al., 1999, p. 104; Smith et al., 1995b, pp. 42-43). Recreation that is characterized by a higher further motion (kinetic recreation) on water e.g., canoeing or cycling at the water edge (Yabes et al., 1997, p. 182; Yamashita, 2002, p. 9). There are other forms of recreation done at a point example swimming, walking, and social meetings are called situation - based recreational experience (Smith et al., 1995b, Pp. 33-35; Yabes et al., 1997 Pp. 182 - 183; Yamashata, 2002, p. 9).

\subsection{Nonpoint Source Pollution}

Nonpoint Source Pollution NPS means a pattern of pollution or diffused source pollution where the source nor the size of the specific emissions can be seen with accuracy. It happens because of snowmelt and rainfall moving through or over the ground. It is seen as a cause of impaired water quality in America which makes it challenging to meet water quality standards for lakes, rivers, streams, and estuaries. The sources of NPS pollution are urban activity, industry, transportation, and agriculture. Generally, NPS pollution comes from runoff, infiltration, drainage, seepage, precipitation, hydrologic modifications, or atmospheric deposition. When the snow melts and rain falls, it transports natural pollutants and pollutants from human activities then into the groundwater, coastal waters, wetlands, lakes, and rivers (EPA 2003 chapter 1, pp. 1-3). Urban pollution comes mostly from urban runoff (Mc Leod et al., 2006). More Total Suspended Solids (TSS) and total Kjeldahl nitrogen (TKN) load are seen in urban runoff to two local point sources. 


\subsection{Economic Benefits of Improving Water Quality}

A study was made on the Tar - Pamlico River the fourth largest in North Carolina. There were issues of algae blooms, diseases in fish, reduction in fish harvest, shellfish bed and underwater grass losses, $30 \%$ of the Tar- Pamlico River affected by pollution, $67 \%$ is because of agricultural NPS pollution (North Carolina Division of Environmental Management, 1988). Surface water quality is affected by agricultural NPS pollution thus it reduces the efficiency of these activities; boating, swimming, fishing, and others. Best management practices (BMPS's) are effective avenue for abating NPS pollution using holding ponds or buffer strips because they are cost-effective. The government of North Carolina State and North Carolina Agricultural Cost - Share Program (ACSP) recently compensates organizations or the use of BMP's.

\subsection{How Green Blue Infrastructure can be executed}

There is a need for policy makers to consider public health and the physical environment. Green space should take places in urban planning not as a luxury, but as a necessity (Maas et al., 2006). Connectivity (housing and transportation) in landscapes can be provided by creating and management of green infrastructures. It will also promote restoration, social bonds, exercise. Housing choice is also a function of green and blue infrastructure (Hartig et al., 2003b). There should be good designs and proper selection of urban vegetation, and maintenance to have a positive influence on water and air quality and do not affect human health, it will also reduce crime rate level (Kuo and Sullivan, 2001). Open views along pedestrian paths and oversight or near buildings can make people feel safe, particularly the women (Krenichyn, 2004). 


\section{CHAPTER 3}

\section{Research Methods}

The research methods observed in this study involves the use of Geographic Information System (GIS) to perform water quality analysis by determining the pollutant concentration in $\mathrm{kg} / \mathrm{yr}$ of the entire study area, using of two landscape models; i-Tree landscape model to determine the air pollutants gases spatial location and areas to prioritize blue infrastructure, and i-Tree design model to find out the stormwater, carbon dioxide removal and avoided, air quality, and economic benefits the individual and collective trees. Lastly case studies were studied to look at existing projects that have similar applications to my study area.

The study area is in Pittsburgh City in Allegheny County, southwest of the U.S. Pennsylvania (PA). It has a population of about 1,225,365. It is categorized as the second largest county in the state with a total of $745 \mathrm{sq} . \mathrm{mi}\left(1939 \mathrm{~km}^{2}\right)$. The elevation ranges from $0 \mathrm{~m}$ to $254 \mathrm{~m}$.

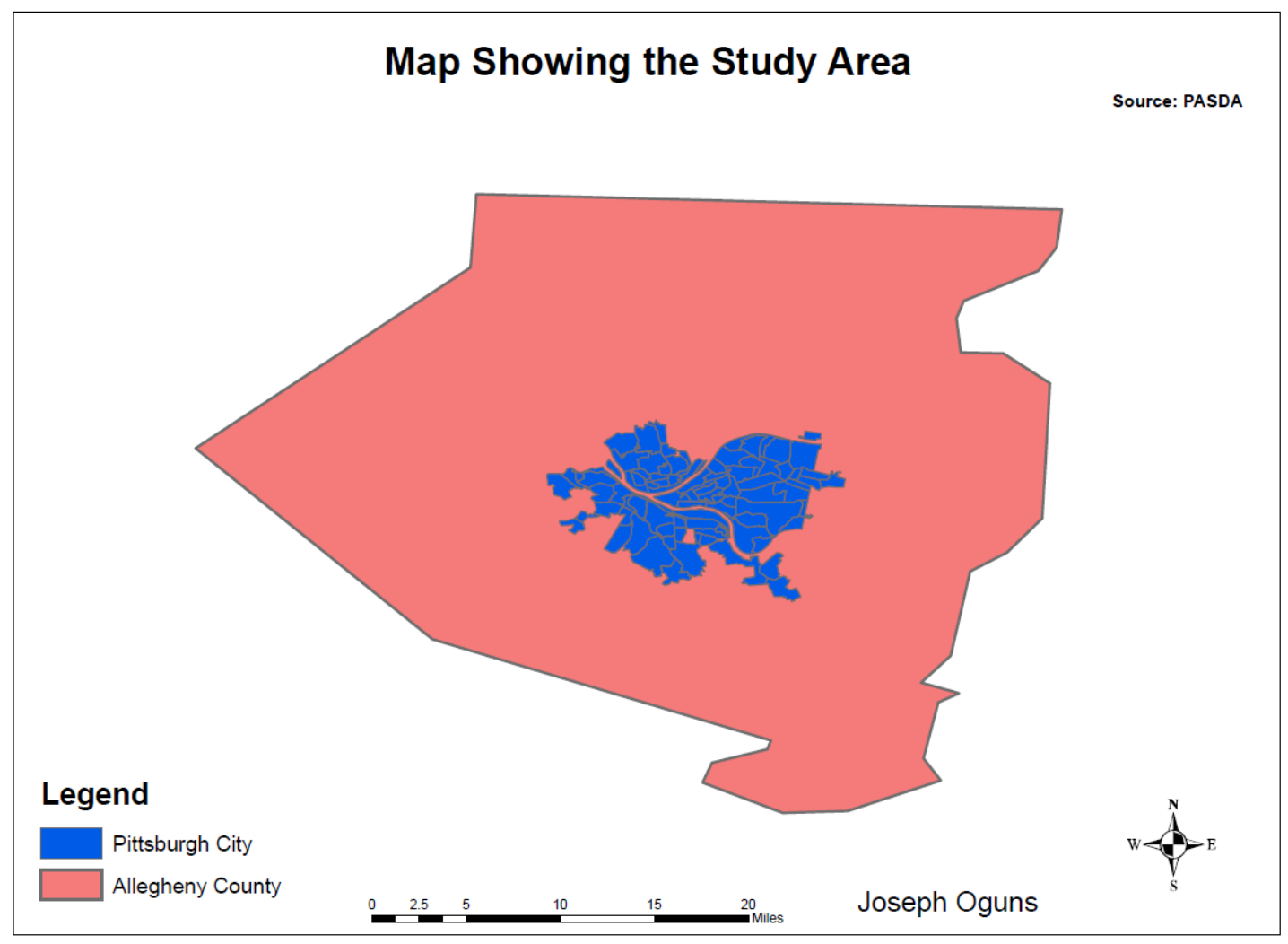


Figure 3: Study area Map

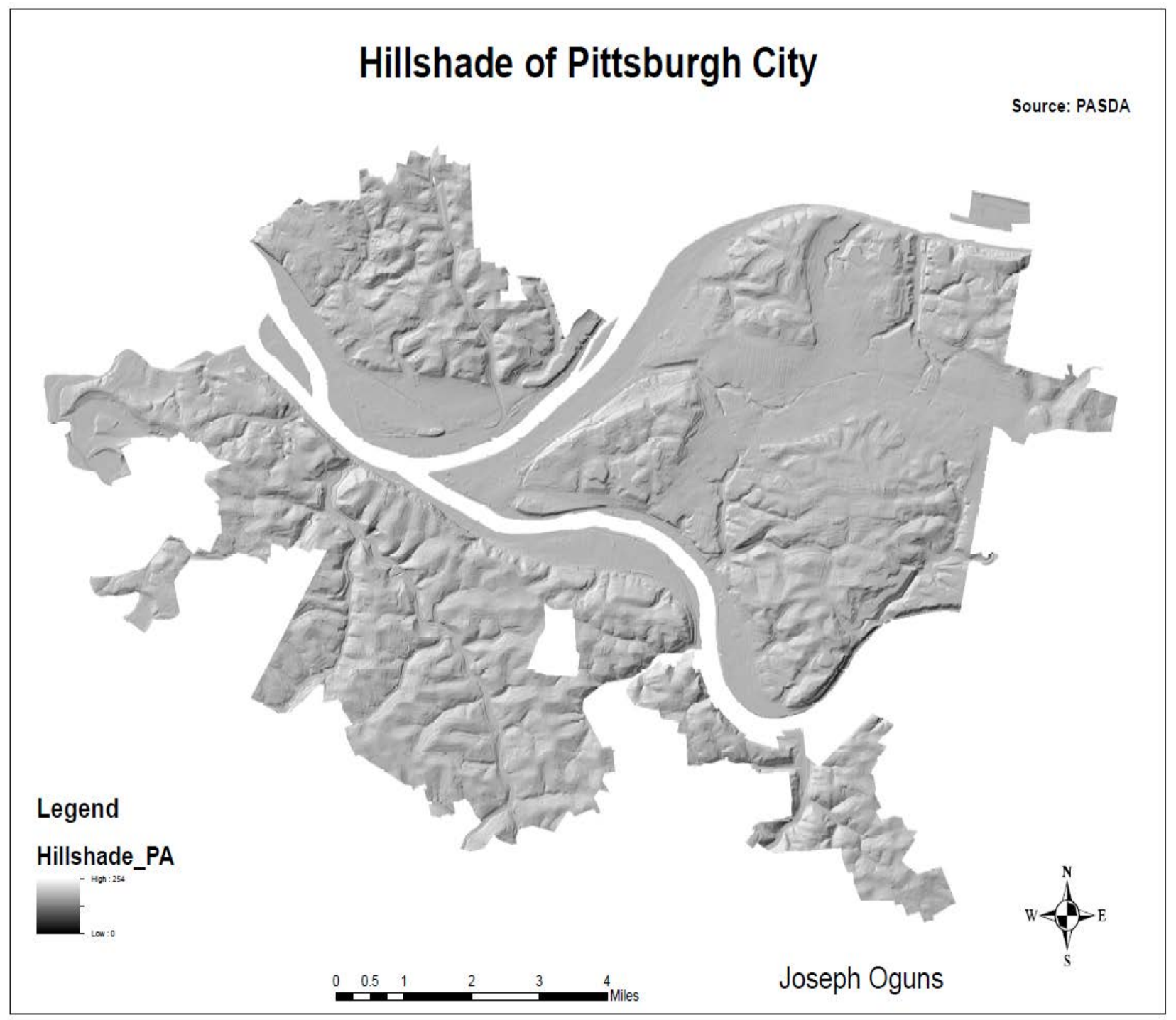

Figure 4: Hillshade of Pittsburgh City 


\subsection{Data Sources and Processing}

To understand how the flow direction works the data and processes shown in figure 6 below were carried out.

\section{Flow Chart}
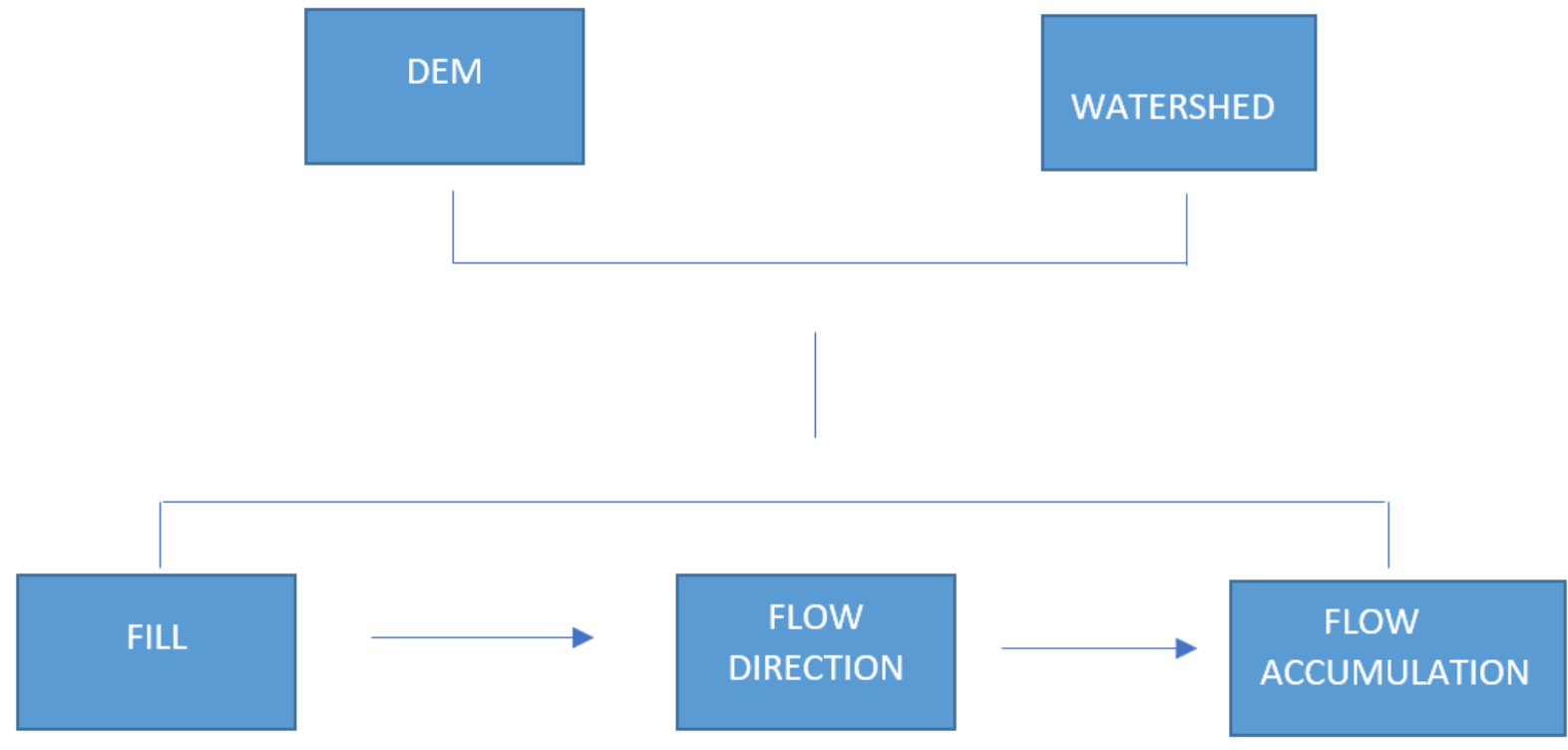

Figure 5: Flow Charts of Water Analysis Steps

This process includes acquiring elevation data for the Allegheny watershed, processing the elevation data, and performing appropriate watershed delineation for the study area. The first step is to get the digital elevation model of the study area from nationalmap.gov (HU- 8 Sub basin). Digital elevation model (DEM) is a 3-Dimensional terrain analysis derived from interpolated surface of topography.

After downloading, the $1 / 3$ arc-second USGS NED n41w081 dataset, it was extracted to the desired folder. The cell size was changed to $10,10(X, Y)$ cell size from 9.259 e -005 , then projected by choosing UTM NAD - 1983 Zone 17N, and applied Int. from the Math tool. The boundary of the Allegheny Watershed was added, and a buffer of 200 meters was applied on the boundary to get a new shapefile Allegheny Boundary, the Deml 
dataset was extracted by mask and the hill shade was also processed to give the maps below. The next step is to get the line work for the streams (watershed) also called basin or catchment referred to an area where rainfall and streams are drain to an outlet or points on stream channels. It can be lakes, streams, wetlands, groundwater and surface water. Accessed from nhd.usgs.gov on NHD Data pre-staged sub regions in GDB and High Resolution, select download and extract the appropriate HUC 8 for the watershed 05020005 Lower Monongahela, 05020006 Youghiogheny, 05010009 Lower Allegheny, 05030101 Upper Ohio, and 05030105 Connoquenessing. The flowline was added and clipped to the watershed boundary as seen below.

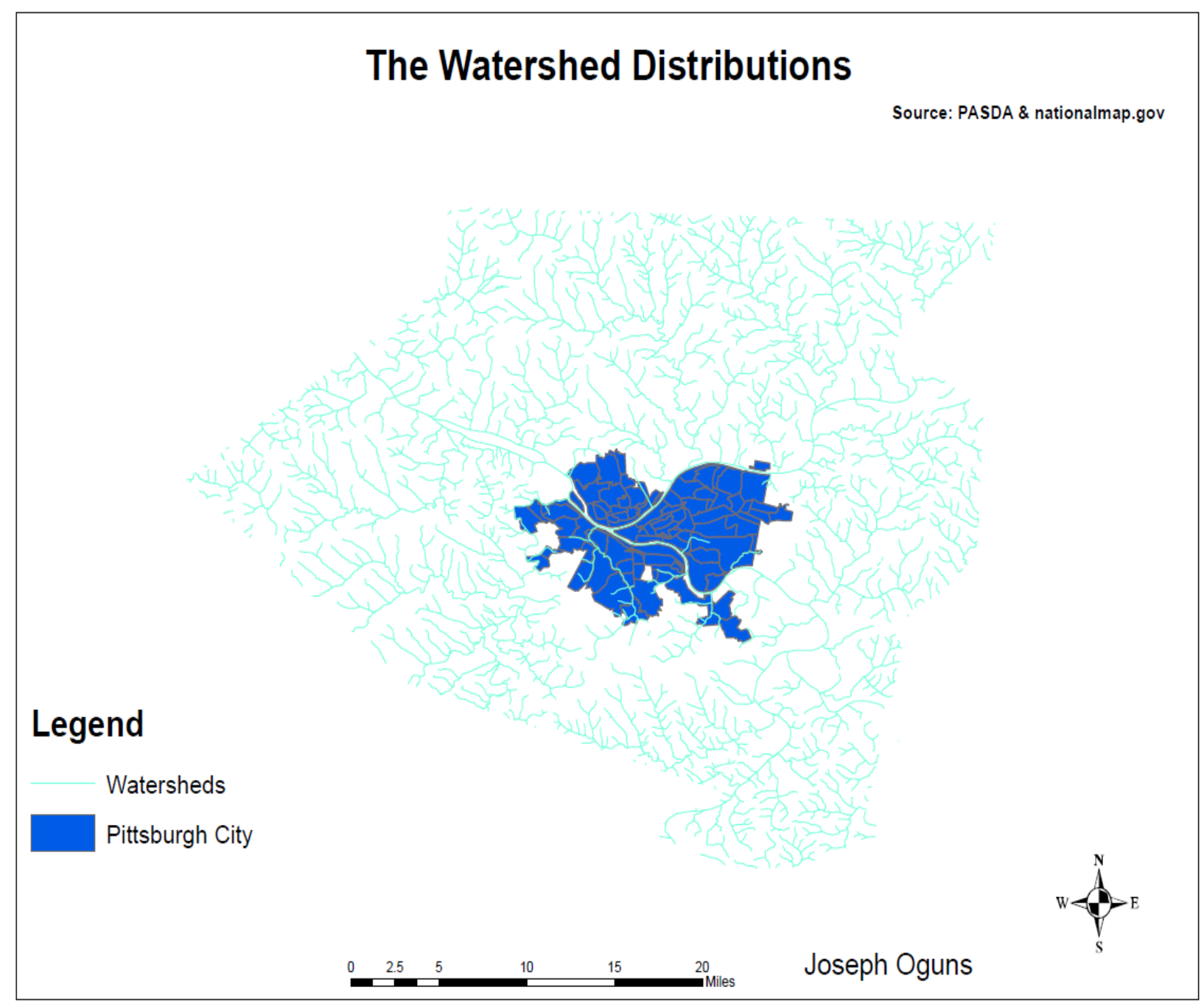

Figure 6: Watershed Distribution Map 
These processes were employed with the aid of the Spatial Analyst Tool (Hydrology) on the study Dem to get the Fill Dem, Flow Direction using Fill Dem as the input raster, then the Flow Accumulation using the Flow Direction as input and changing the output data as an integer. The output maps are seen below:

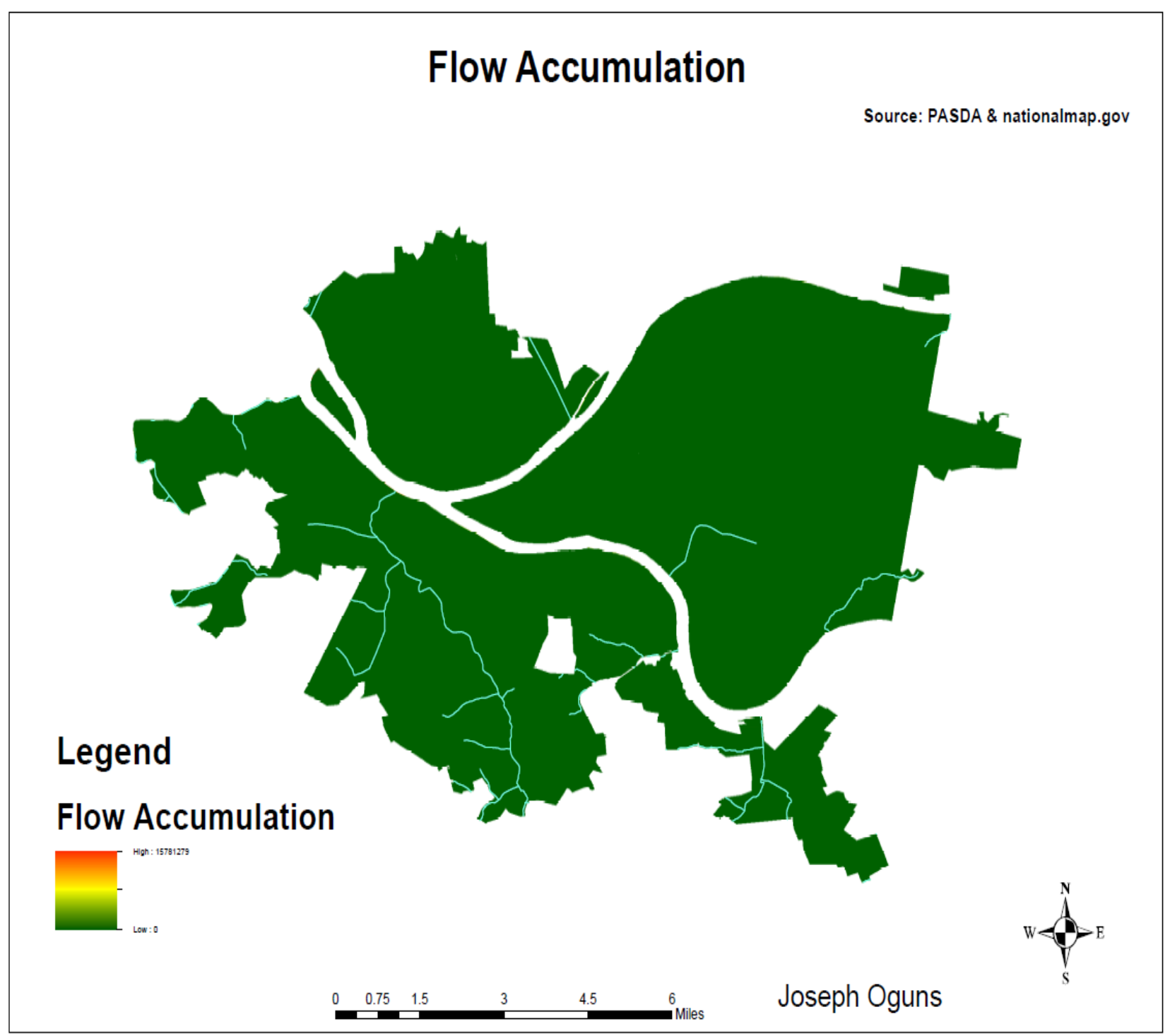

Figure 7: Flow Accumulation Map

The next step was on working on the vector versus the raster grid, using the flow accumulation and reclassifying it to 2 classes from the legend properties, to get the raster stream grid. The flow accumulation was queried using 2000 fac units $10 \mathrm{~m}$ cell size that corresponds to fifty acres. The Thin Command was used to get rid of the raster cells next 
to each other. Reclassify tool was further used using Thin streams as input and naming 0 as NoData and 1 as 1 to get an output called watergrid. The maps are shown below:

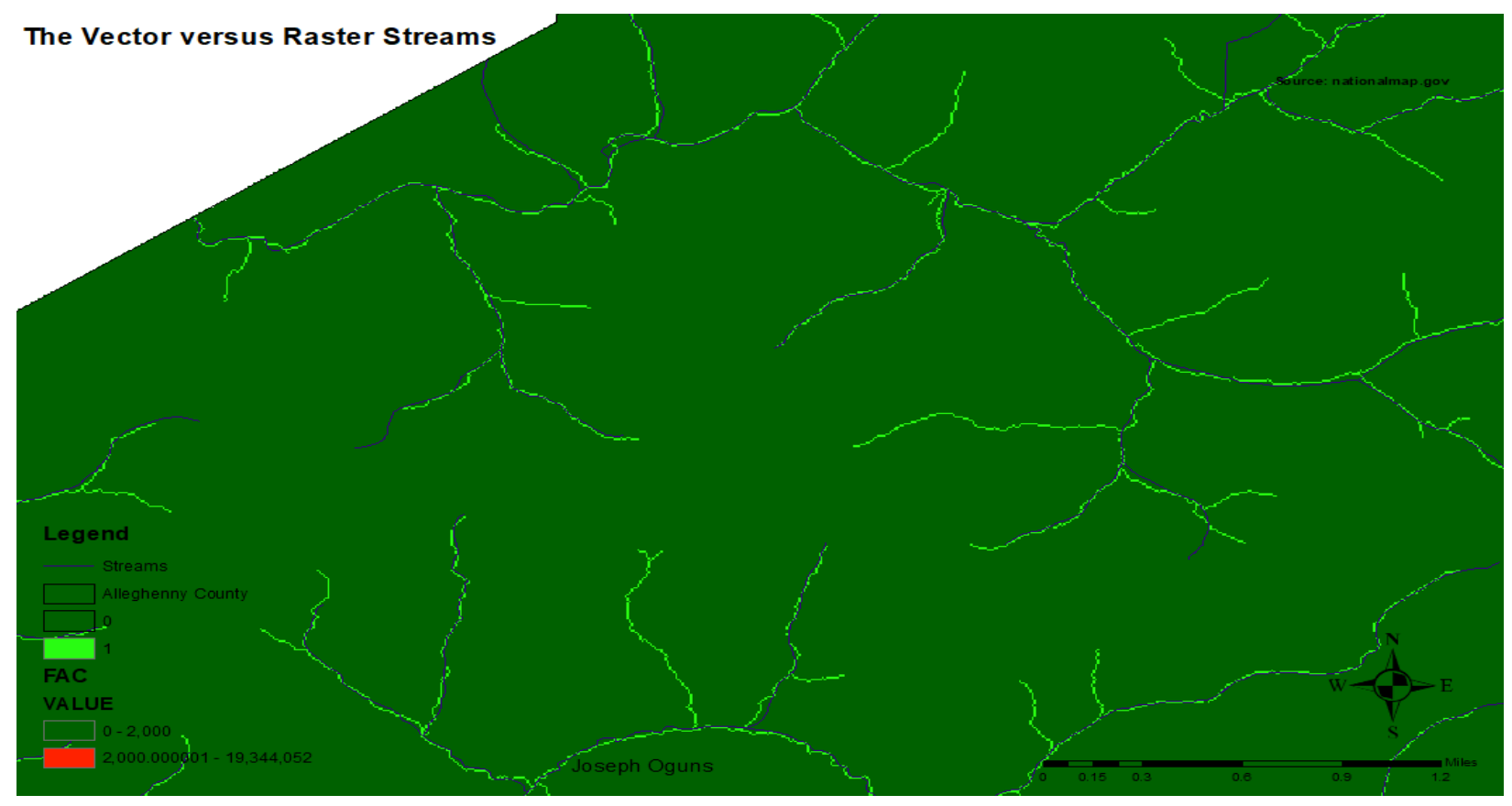

Figure 8: The vector and Raster Streams Comparism 


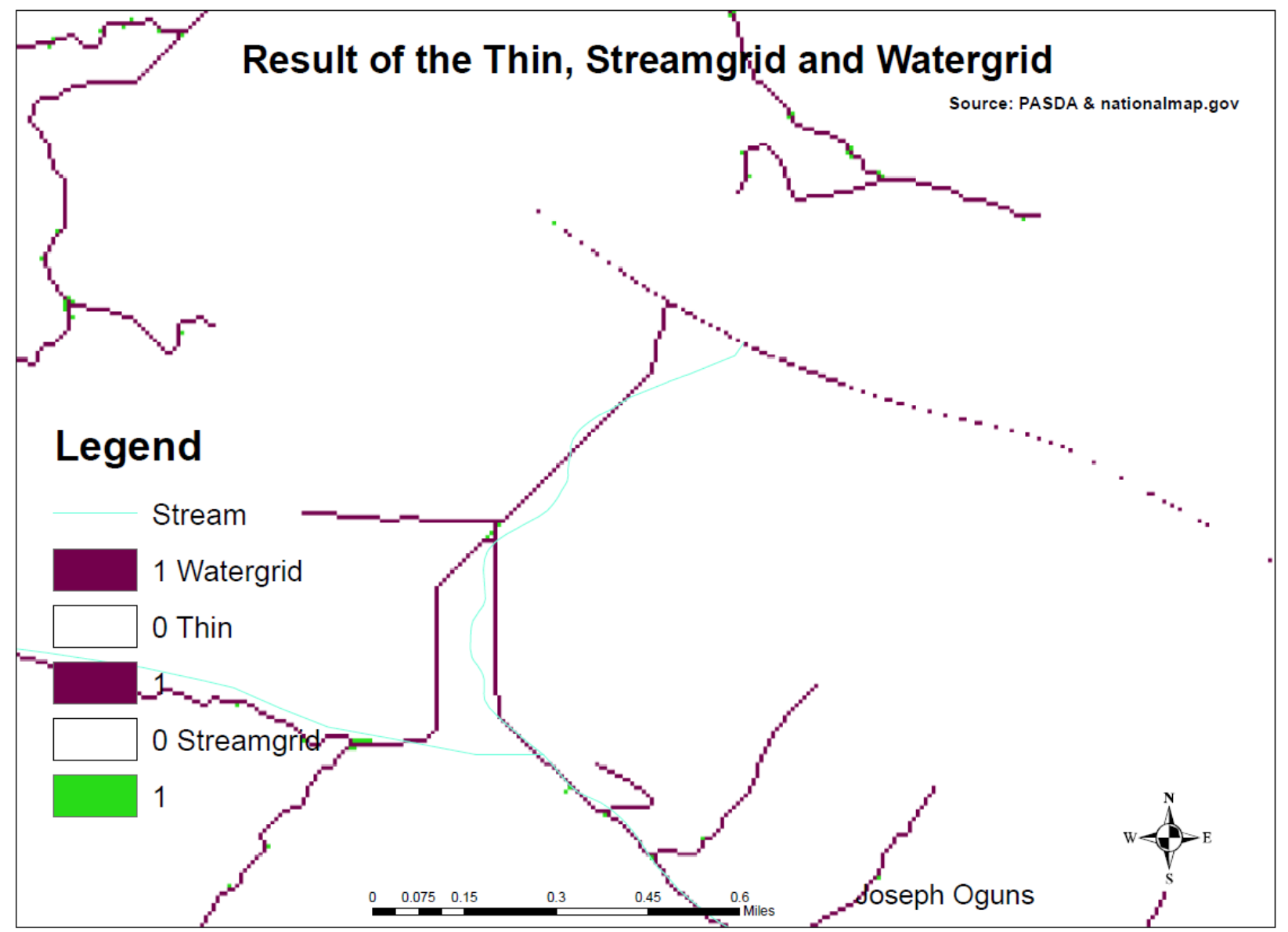

Figure 9: Thin, Streamgrid and Watergrid Result Map

The elevation was raised by 100 m using the Raster Calculator ("filldem" + 100) to get an output dem100. Then the focal mean values of the dem for the raster streams were processed using the Focal Statistics tool. In addition, the Con tool was used using watergrid as the input conditional raster and the focalmin as the input true raster or constant value and strmelev as the output.

The Raster Calculator was used to multiply dem100 and Is Null_Strme1 to get an output step1, after which the Con tool was used to get an output burndem using step1 as input conditional raster and dem 100 as input true raster. Using the burndem as an input surface raster, the filldem2; flow direction2 flow accumulation2 were processed from the Hydrology tool. Fac2 was queried using "fac2" >= 2000 to get watergrid2 with the Raster Calculator tool. 


\subsection{Determining the Water Quality}

GIS model was used in this analysis, DEM, Watershed, Precipitation, and the Land Cover of the focus area were used in the process. TSS (Total Suspended Solids) mg/L values were assigned to the NLCD 2011.

\begin{tabular}{|c|c|c|}
\hline 2011 Land Cover Value & Land Cover Types & $\mathrm{Mg} / \mathrm{L}$ of TSS \\
\hline 11 & Open Water & 3 \\
\hline 21 & Developed, Open Space & 19 \\
\hline 22 & Developed, Low Intensity & 20 \\
\hline 23 & $\begin{array}{l}\text { Developed, Medium } \\
\text { Intensity }\end{array}$ & 25 \\
\hline 24 & Developed, High Intensity & 35 \\
\hline 31 & $\begin{array}{c}\text { Barren Land } \\
\text { (Rocks/Sand/Clay) }\end{array}$ & 30 \\
\hline 41 & Deciduous forest & 16 \\
\hline 42 & Coniferous forest & 14 \\
\hline 43 & Mixed forest & 15 \\
\hline 52 & Dwarf Scrub & 22 \\
\hline 71 & Grassland/Herbaceous & 19 \\
\hline 81 & Pasture/ Hay & 27 \\
\hline 82 & Cultivated Crops & 27 \\
\hline 90 & Woody Wetlands & 8 \\
\hline 95 & $\begin{array}{c}\text { Emergent Herbaceous } \\
\text { Wetlands }\end{array}$ & 8 \\
\hline
\end{tabular}

Table 1: Total Suspended Solids (TSS) Values Versus NLCD 2011 
The reclassified NLCD 2011 was given an output emc_tss, the map is seen below.

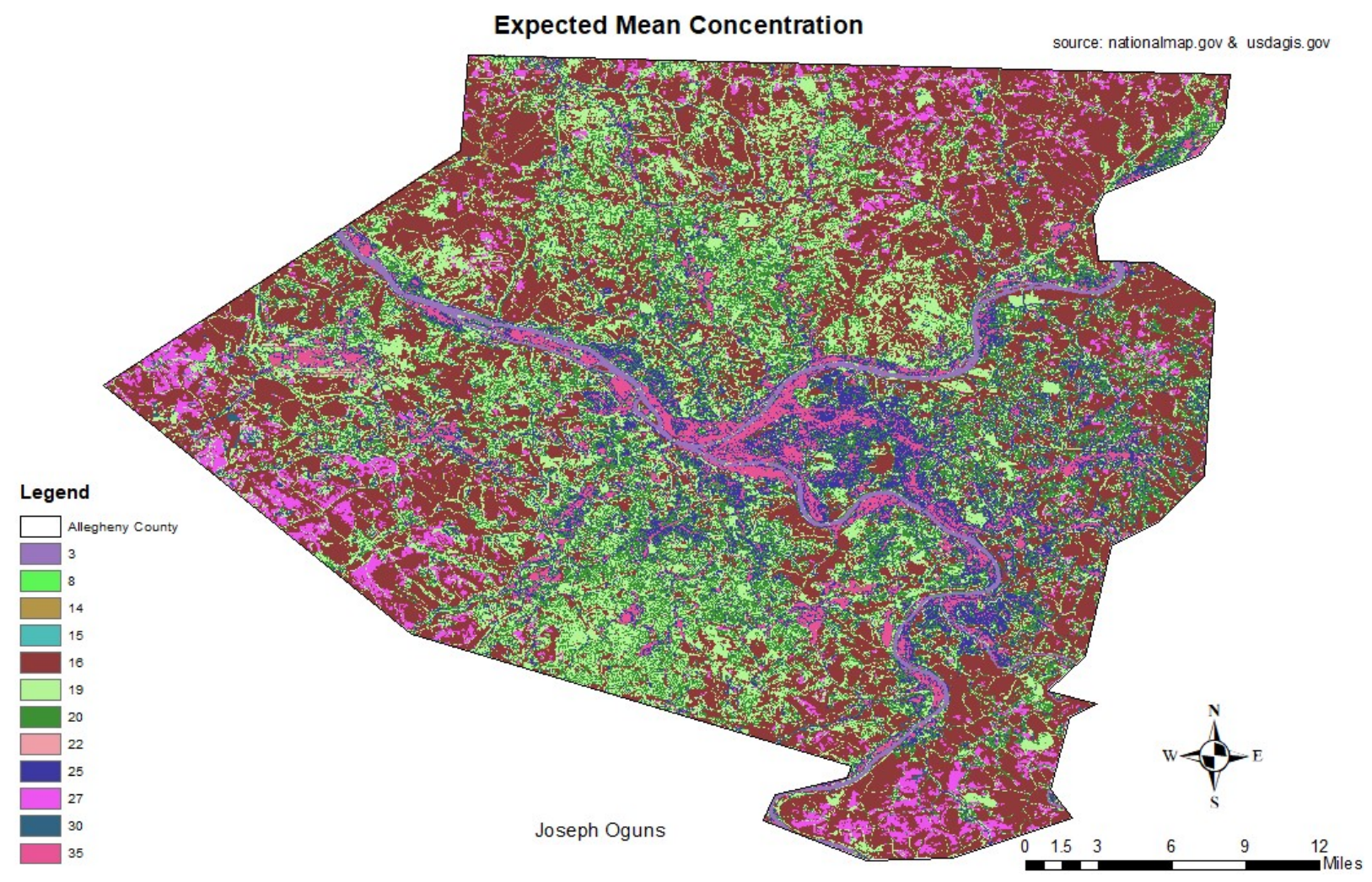

Figure 10: Expected Mean Concentration Map

To estimate Annual loadings throughout the watershed, the pollutant mass contribution that each cell makes to downstream pollutant loading was calculated by taking the product of the expected mean concentration and runoff associated with the cell or

Load $($ mass / time $)=$ Expected mean Concentration EMC (Mass / Volume $) * \mathrm{Q}($ Volume / time)

$L=K * Q * E M C * A$

$\mathrm{K}=$ Constant $=10^{-6} \mathrm{~kg}-\mathrm{m}-\mathrm{L} / \mathrm{mg}-\mathrm{mm}-\mathrm{m}^{3}$ (Converting the units)

$\mathrm{Q}=$ Units in $\mathrm{mm} / \mathrm{yr}$.

$\mathrm{EMC}=$ in $\mathrm{mg} /$ liter $\mathrm{A}=$ Area of one grid cell

$\mathrm{L}=$ in $\mathrm{kg} / \mathrm{yr}$. (Loading) 
To determine the cell-based loading grid raster calculator tool was used to multiply the runoff with the reclassified emc_tss. The precipitation data (Climate Prism Raster 1981 2010 Annual Average Maximum Precipitation by state) was downloaded from gdg.sc.egov.usda.gov. The 30-yr. annual depth of stream flow of $0.655474 \mathrm{~mm}$ was used and multiplied with the annual precipitation total in $\mathrm{mm}$ to give the runoff. The cell load was gotten by multiplying the runoff with emc_tss.

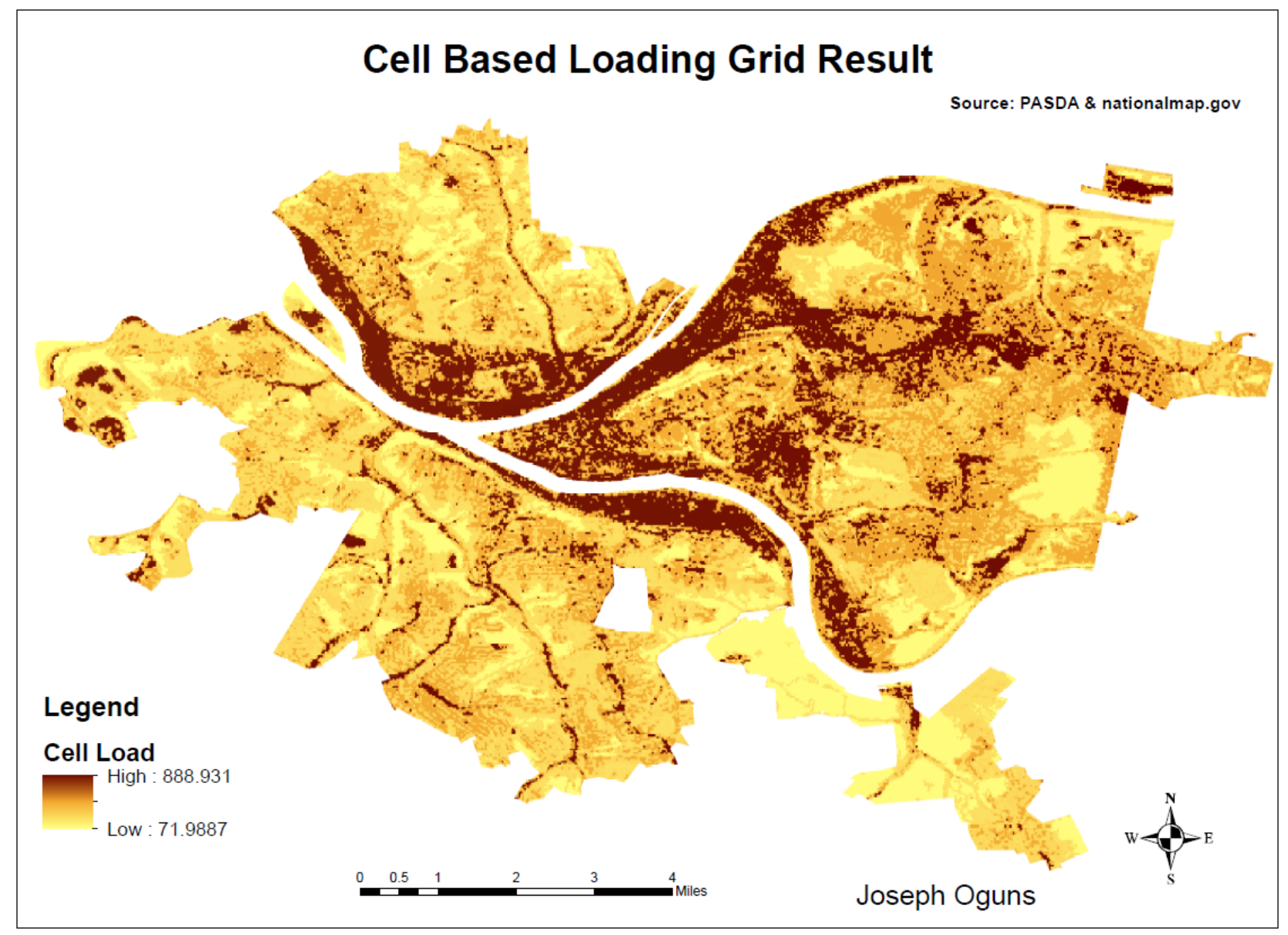

Figure 11: Cell Based Loading Grid Map

The cumulative load output in $\mathrm{kg} / \mathrm{yr}$. for both in streams and out streams cells were gotten with flow accumulation tool using the flow direction 2 (fdr2) to get an output Part A and multiplying it with 0.0001 . 


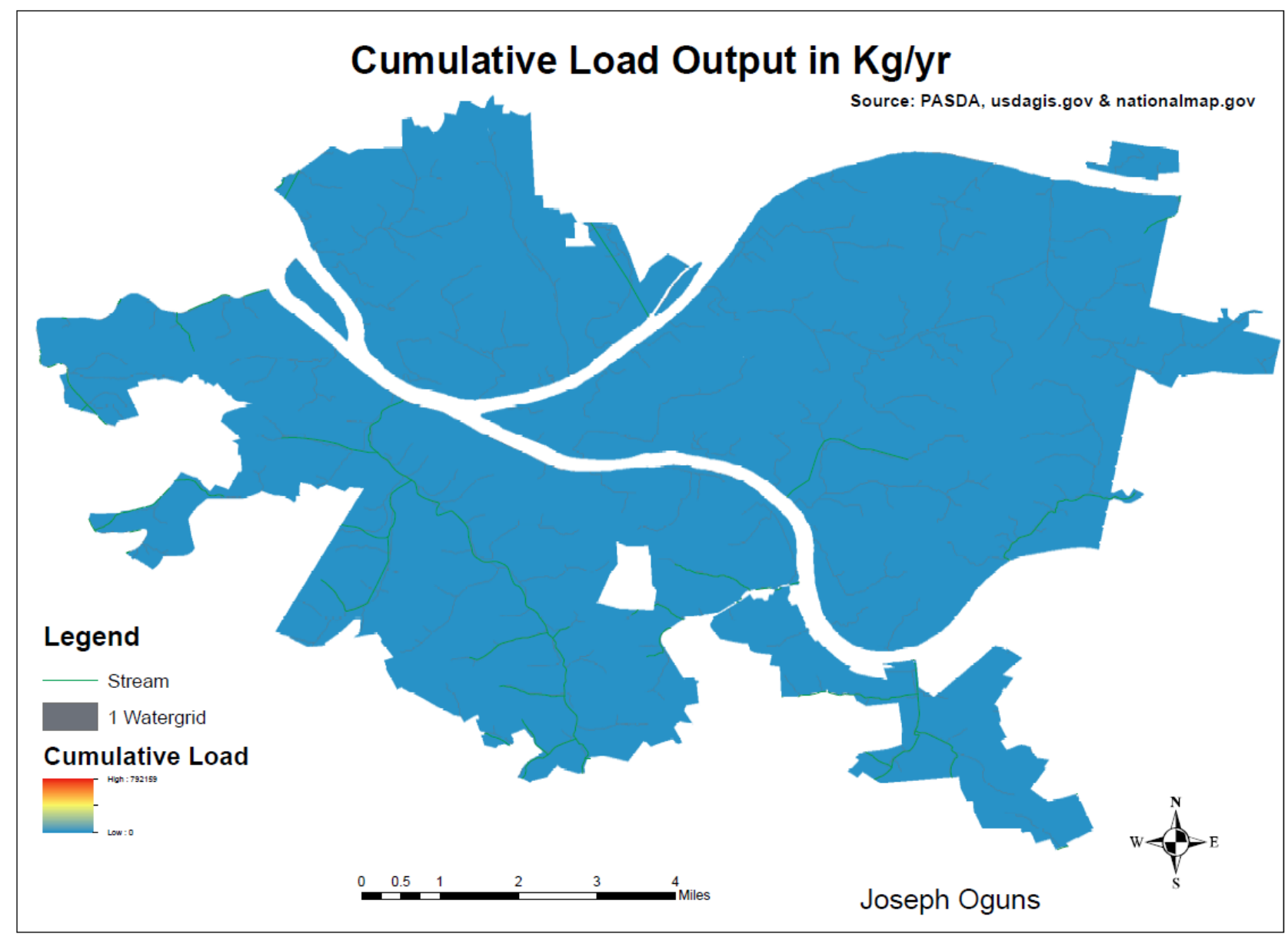

Figure 12: Cumulative Load Output Map in Kg/yr.

To create a grid of concentration this equation was used

$C(m g / L)=L(k g / y r.) / Q\left(m^{3} / y r.\right) * .001 m^{3} / L$

From the model this query was used

("tss_load" / "Cu_runoff2") * 1000 to get the tss_conc.

It helps to determine the pollutant concentrations within the area. 


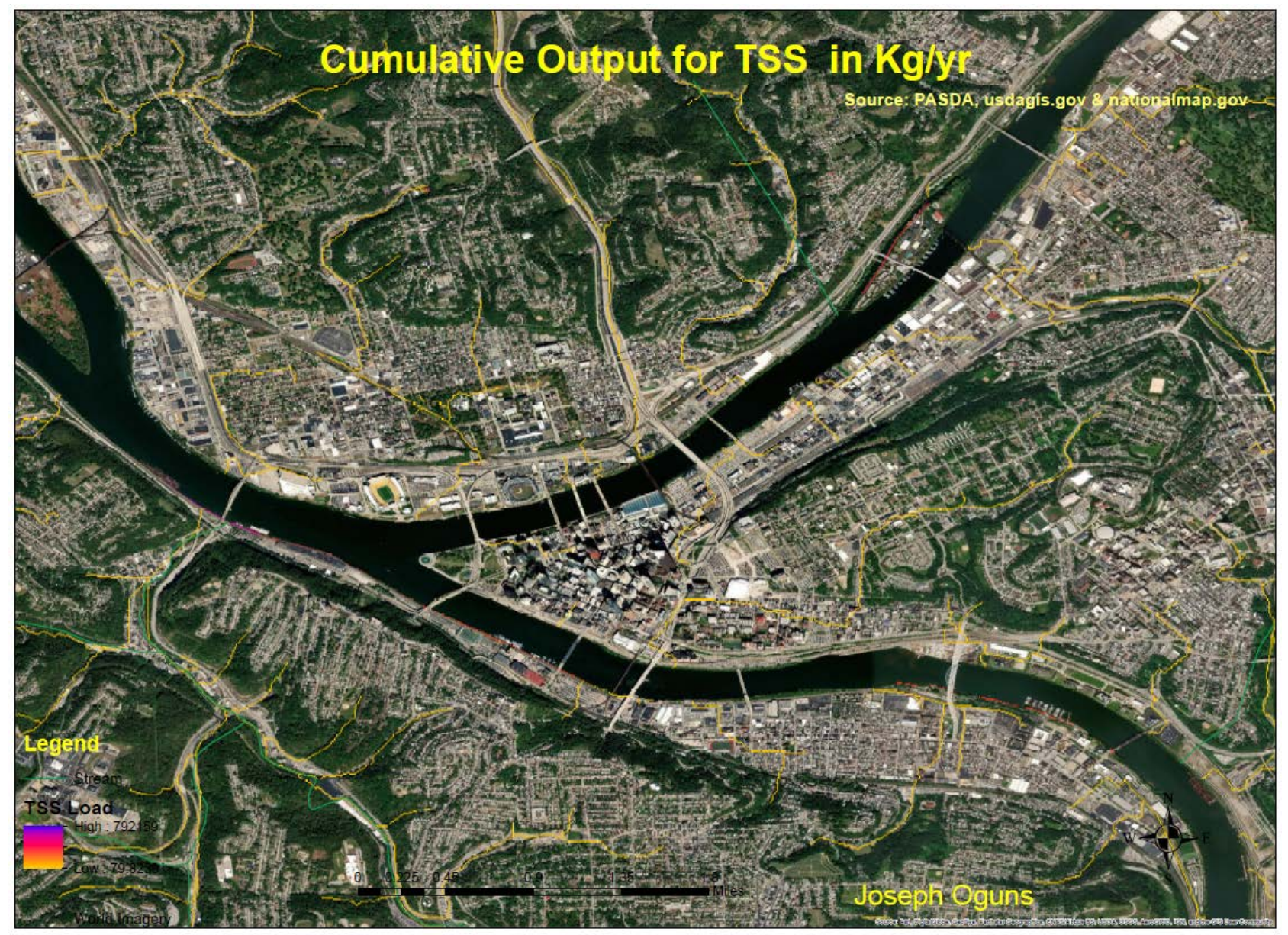

Figure 13: Cumulative Load Output in $\mathrm{Kg} / \mathrm{yr}$ with Base Map.

From the water quality model, one can identify areas that have high TSS level which gives an idea on the water quality of the area, Total Suspended Solids are parameters used in determining water quality suspended in water. TSS can be because of surface runoff, decaying plants and animals, and soil erosion. The areas pointed out as areas to prioritize planting by the i- Tree Landscape model also among the area having high TSS level from the figure 12 above. High concentrations of suspended solids can cause many problems for stream health and aquatic life.

\section{The Limitations of the water quality model}

It does not consider infiltration, interflow, or groundwater flow additions; It uses mean annual runoff and flow measures with one-time water quality sampling data; It does not include atmospheric conditions such as evapotranspiration or temperature. 


\section{Advantages of the water quality Model}

The results include surface runoff from point and non - point sources.

It is a landscape, GIS/ watershed model and not a receiving water model.

It is a deterministic simulation model.

It is easy to analyze the output and query functions from results

\subsection{The i- Tree Models}

\subsection{1. i-Tree Landscape}

i-Tree Landscape is a landscape model that gives other tree benefits which is different from physical benefits of beauty and refuge. The benefits include: enhancing water quality reducing urban heat island, stormwater mitigation, air pollution (ozone, sulfur dioxide, nitrogen dioxide, and particulate matter) spatial location, and areas to prioritize tree planting in a study area. This model uses canopy cover data National Land Cover Database (NLCD) 2011 and new high-resolution urban tree canopy data in partnership with U.S. Forest Service, Society of Municipal Arborists, Arbor Day Foundation, Casey Trees, Environmental Science and Forestry, and International Society of Arboriculture.

It is a five steps process:

1. Find Location/s to be studied by selecting area/s of interest with the control panel at the top right of the interface which has Map Layers, Canopy, and Land Layers, and Base Maps dataset to explore.

2. Explore Location Data to view data in English or Metric units, chart or table format. It gives one an idea of the impervious and canopy cover, land cover, U.S. Census, human health risk data, and forest data.

3. Tree Benefits of the selected area is seen in metric or English units under the map in chart or table format beneath the map.

4. Prioritize Tree Planting; areas to prioritize tree planting can be seen at this stage for sustainable practice and benefits. It can be weighed on a scale of 1 and 100 with the chosen method equals 100. 
5. Generating Results is the final stage where one can see the overall report and choose the output format desired by clicking on the done button. The sections to be seen includes location information, prioritization, and tree benefits.

\section{i-Tree Landscape Findings}

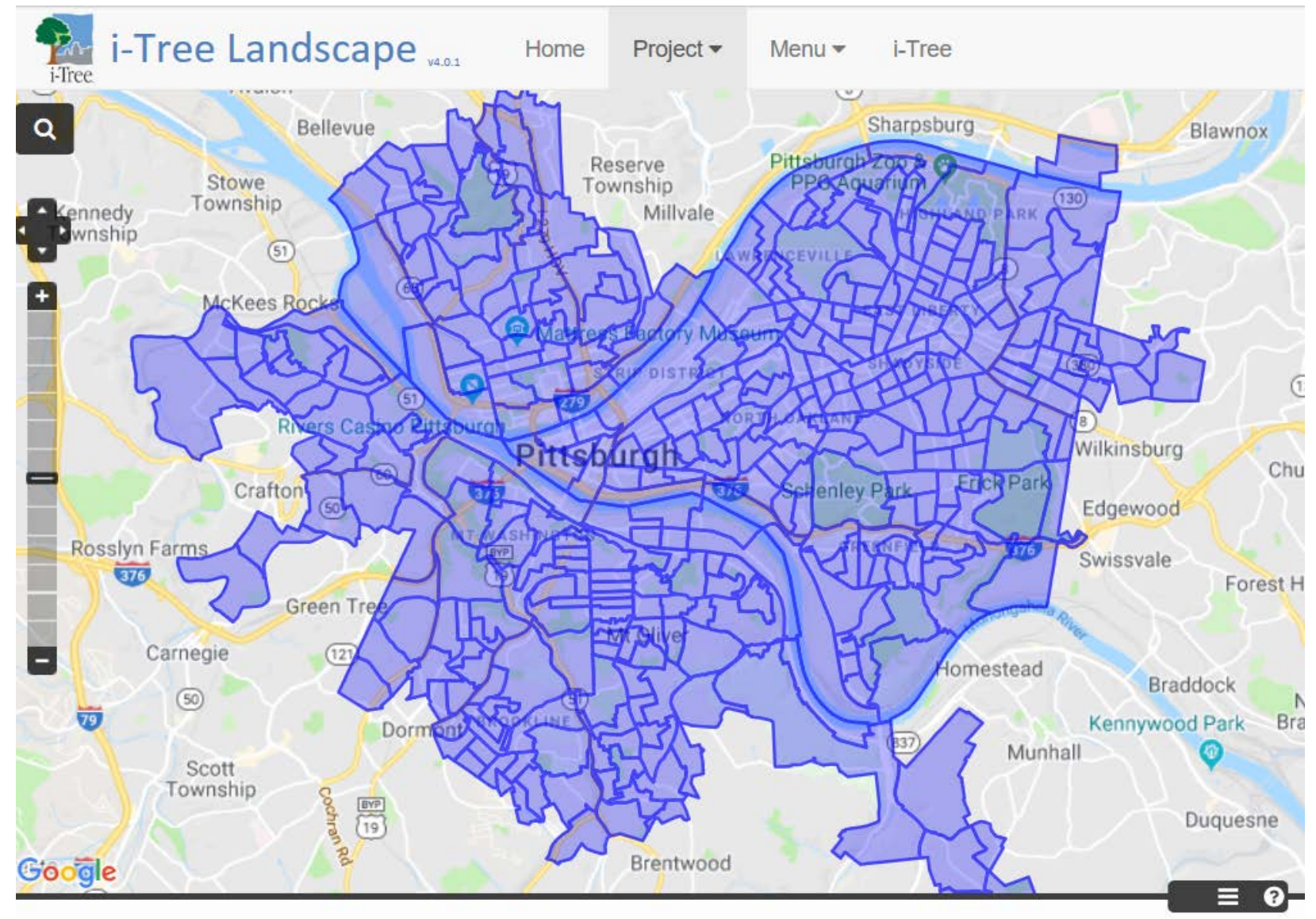

Figure 14: Map of the Study area (i-Tree Landscape)

\begin{tabular}{|l|l|l|l|l|l|l|l|l|}
\hline \multirow{2}{*}{$\begin{array}{l}\text { Canopy \& } \\
\text { Impervious }\end{array}$} & \multicolumn{2}{|l|}{ Area } & \multicolumn{2}{l|}{ Canopy } & \multicolumn{2}{l|}{ Impervious } & \multicolumn{2}{l|}{ Plantable Space } \\
\cline { 2 - 9 } & Acre & Percentage & Acre & Percentage & Acre & Percentage & Acre & Percentage \\
\hline $\begin{array}{l}\text { Selection } \\
\text { Total }\end{array}$ & $37,899.8$ & 100.00 & $15,963.0$ & 44.43 & $14,703.9$ & 40.89 & 5352.9 & 14.90 \\
\hline
\end{tabular}

Table 2: Canopy, Impervious, and Plantable Spaces Table 


\begin{tabular}{|l|l|l|l|l|l|l|l|l|}
\hline \multirow{2}{*}{$\begin{array}{l}\text { Canopy \& } \\
\text { Impervious }\end{array}$} & \multicolumn{2}{|l|}{ Carbon Storage } & \multicolumn{2}{l|}{$\begin{array}{l}\text { Carbon } \\
\text { Sequestration }\end{array}$} & \multicolumn{2}{l|}{$\begin{array}{l}\text { Co2 Equivalent } \\
\text { Storage }\end{array}$} & \multicolumn{2}{l|}{$\begin{array}{l}\text { Co2 Equivalent } \\
\text { Sequestration }\end{array}$} \\
\cline { 2 - 9 } & $\$$ & Short Ton & $\$ / y r$ & t/yr & $\$$ & Short Ton & \$/yr. & t/yr. \\
\hline $\begin{array}{l}\text { Selection } \\
\text { Total }\end{array}$ & $63,281,109$ & $370,922.6$ & $1,241,224$ & $7,277.8$ & $63,261,109$ & $1,360,049.3$ & $1,241,224$ & $26,685.1$ \\
\hline
\end{tabular}

Table 3: Carbon and $\mathrm{CO}_{2}$ Storage and Sequestration

\begin{tabular}{|c|c|c|c|c|c|c|c|c|c|c|c|c|c|c|}
\hline $\begin{array}{l}\text { Air } \\
\text { Pollu } \\
\text { tion } \\
\text { Rem } \\
\text { oval }\end{array}$ & \$/yr & Ib/yr & $\begin{array}{l}\text { Healt } \\
h \\
\text { Incid } \\
\text { ence }\end{array}$ & $\begin{array}{l}\text { Emer } \\
\text { genc } \\
y \\
\text { Roo } \\
\text { m } \\
\text { Visit } \\
\text { s }\end{array}$ & $\begin{array}{l}\text { Hospi } \\
\text { tal } \\
\text { Admi } \\
\text { ssion } \\
\text { s }\end{array}$ & $\begin{array}{l}\text { Acut } \\
\text { e } \\
\text { Respi } \\
\text { rator } \\
\text { y } \\
\text { Syste } \\
\text { m }\end{array}$ & $\begin{array}{l}\text { Asth } \\
\text { ma } \\
\text { Exa } \\
\text { cerb } \\
\text { atio } \\
\mathrm{n}\end{array}$ & $\begin{array}{l}\text { Morta } \\
\text { lity }\end{array}$ & $\begin{array}{l}\text { Sc } \\
\text { ho } \\
\text { ol } \\
\text { Lo } \\
\text { ss } \\
\text { Da } \\
\text { ys }\end{array}$ & $\begin{array}{l}\text { Hosp } \\
\text { ital } \\
\text { Admi } \\
\text { ssion } \\
\mathrm{s}, \\
\text { Cardi } \\
\text { ovas } \\
\text { cular }\end{array}$ & $\begin{array}{l}\text { Acut } \\
\text { e } \\
\text { Bron } \\
\text { chitis }\end{array}$ & $\begin{array}{l}\text { Uppe } \\
r \\
\text { Respi } \\
\text { rator } \\
\text { y } \\
\text { Symp } \\
\text { toms }\end{array}$ & $\begin{array}{l}\text { Low } \\
\text { er } \\
\text { Res } \\
\text { pirat } \\
\text { ory } \\
\text { Sym } \\
\text { pto } \\
\text { ms }\end{array}$ & $\begin{array}{l}\text { Wor } \\
k \\
\text { Los } \\
\text { s } \\
\text { Day } \\
\text { s }\end{array}$ \\
\hline $\begin{array}{l}\text { Sele } \\
\text { ction } \\
\text { Total }\end{array}$ & $\begin{array}{l}7,345 \\
, 840\end{array}$ & $\begin{array}{l}1,091 \\
, 598 . \\
4\end{array}$ & 1184 & 0.03 & 0.22 & $\begin{array}{l}907.5 \\
2\end{array}$ & 185 & 0.34 & $\begin{array}{l}59 . \\
82\end{array}$ & 0.01 & 0.02 & 2.08 & 2.50 & $\begin{array}{l}26.1 \\
6\end{array}$ \\
\hline
\end{tabular}

Table 4: Total Air Pollution Removal

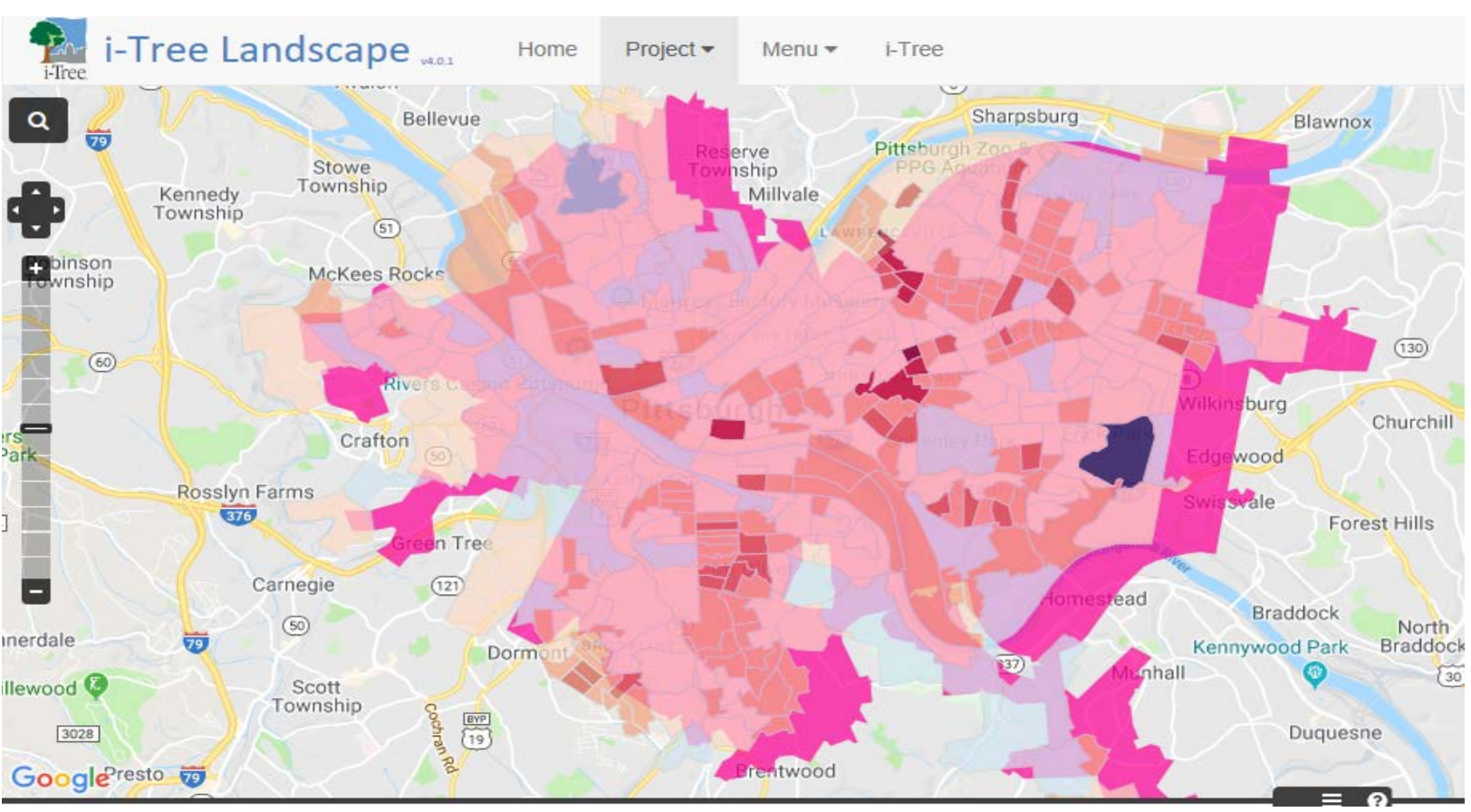

Carbon Monoxide (1971

Standard)

Figure 15: CO Areas in Pittsburgh City 


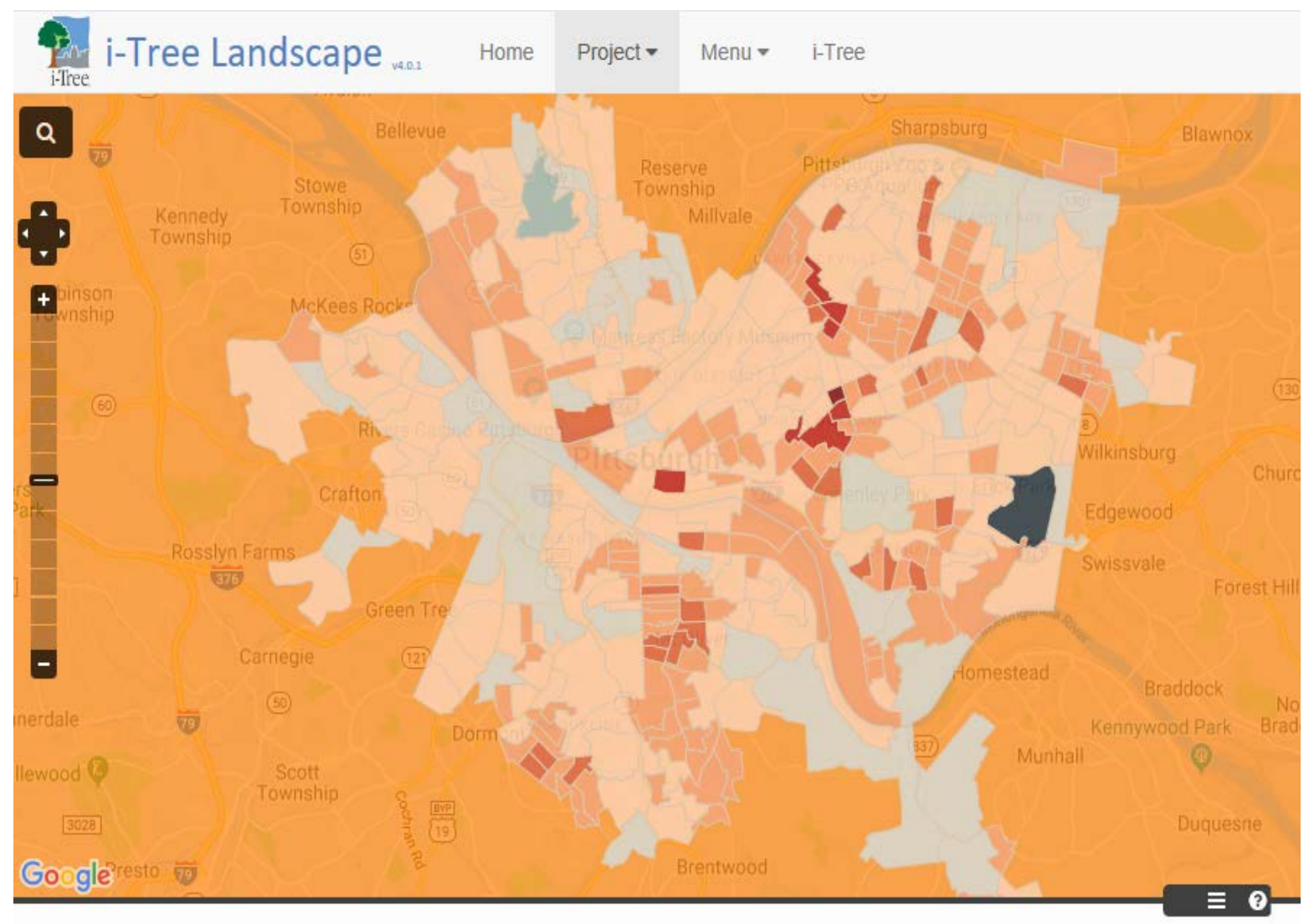

Ozone (O3) Maximum

Good [50 thru $54(\mathrm{ppb})]$

Moderate [55 thru $70(\mathrm{ppb})]$

Unhealthy for Sensitive Groups [71 thru 85 (ppb)]

Unhealthy [86 thru 105 (ppb)]

Very Unhealthy $[106+(\mathrm{ppb})]$

The maximum OS (PpD) value for all days in 2008 from U.S. EPA Downscaler Modal - epa gov.

Figure 16: Ozone $\mathrm{O}_{3}$ Maximum Areas in Pittsburgh 


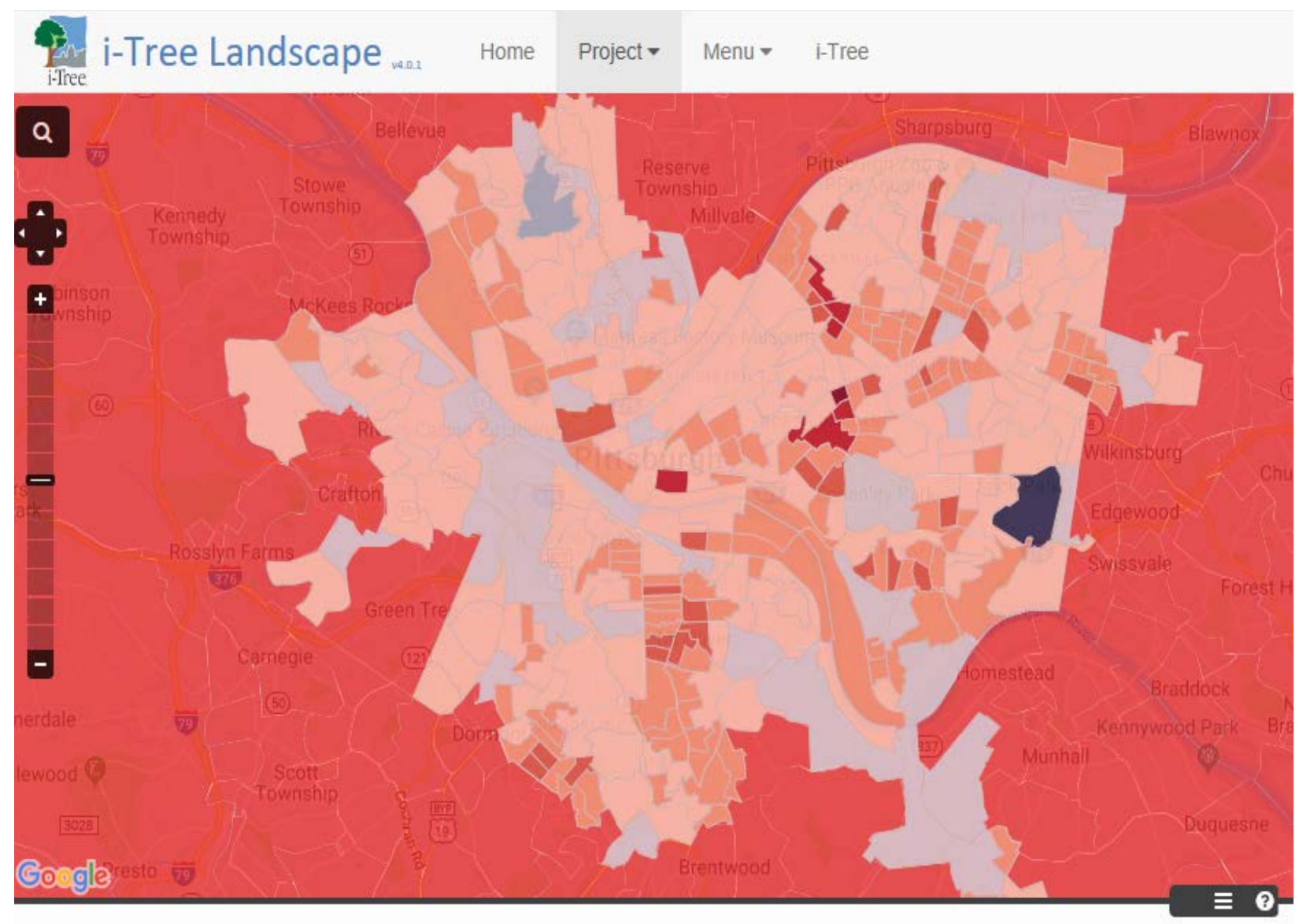

Particulate Matter (PM2.5) Average

Good [4 thru $6\left(\mu \mathrm{g} / \mathrm{m}^{3}\right)$ ]

Moderate $\left[7\right.$ thru $\left.9\left(\mathrm{\mu g} / \mathrm{m}^{3}\right)\right]$

Unhealthy for Sensitive Groups [10 thru $12\left(\mathrm{\mu g} / \mathrm{m}^{3}\right)$ ]

Unhea7thy [13 thru $\left.15\left(\mu \mathrm{g} / \mathrm{m}^{3}\right)\right]$

Very Unhea1thy $\left[16+\left(\mu \mathrm{g} / \mathrm{m}^{3}\right)\right]$

The average PM2. 5 ( $\mu \mathrm{g} / \mathrm{m} 3)$ value for all days in 2000 from U.S. EPA Downscaler Modal- epa gov

Figure 17: Particulate Matter 2.5 Average Areas in Pittsburgh 


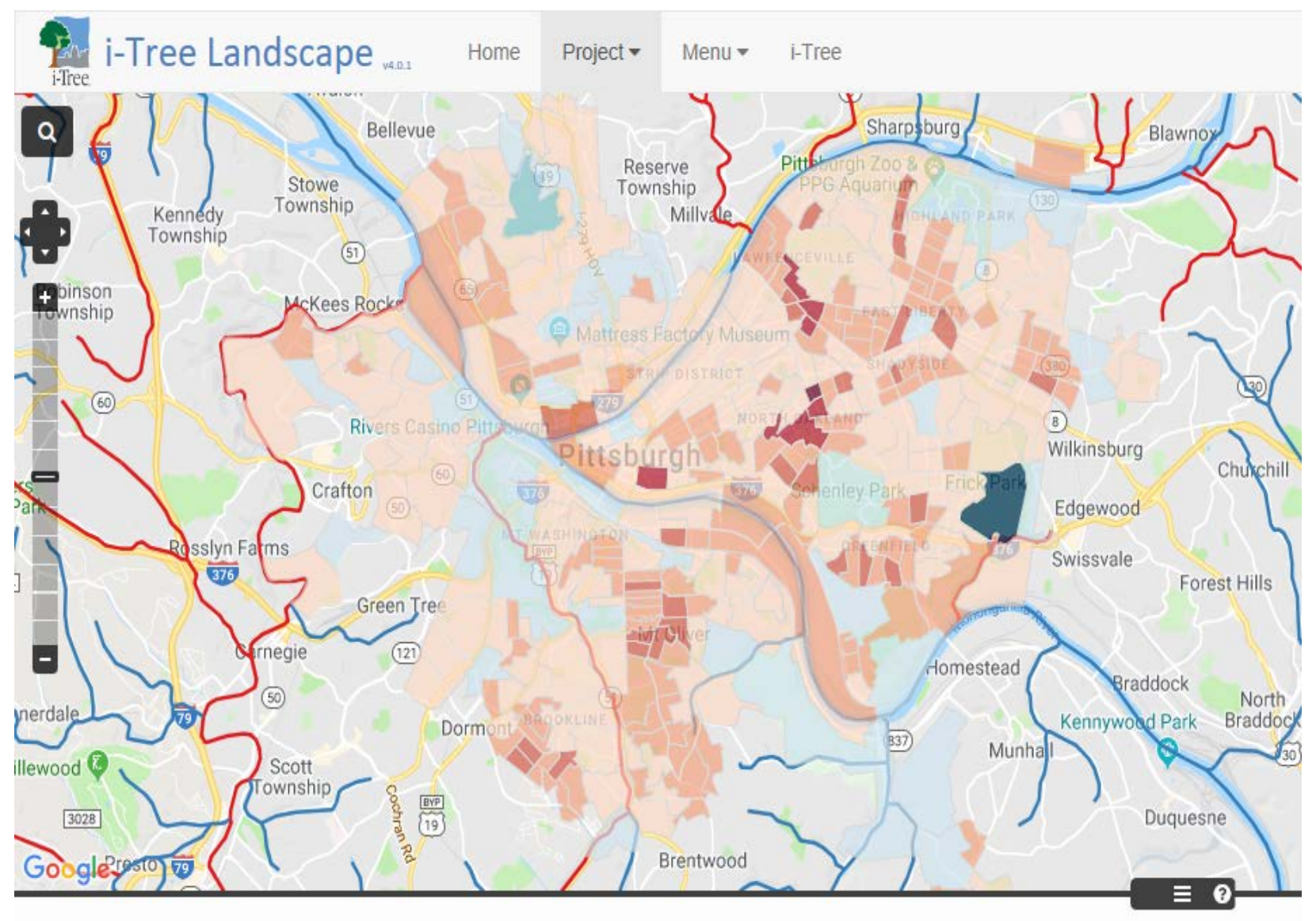

EPA Impaired Waters

\section{Impaired \\ Not Impaired}

Dataset showing NHD (National Hydrography Dataset) Watercourses that are classified as impaired

Figure 18: EPA Impaired Waters in Pittsburgh 


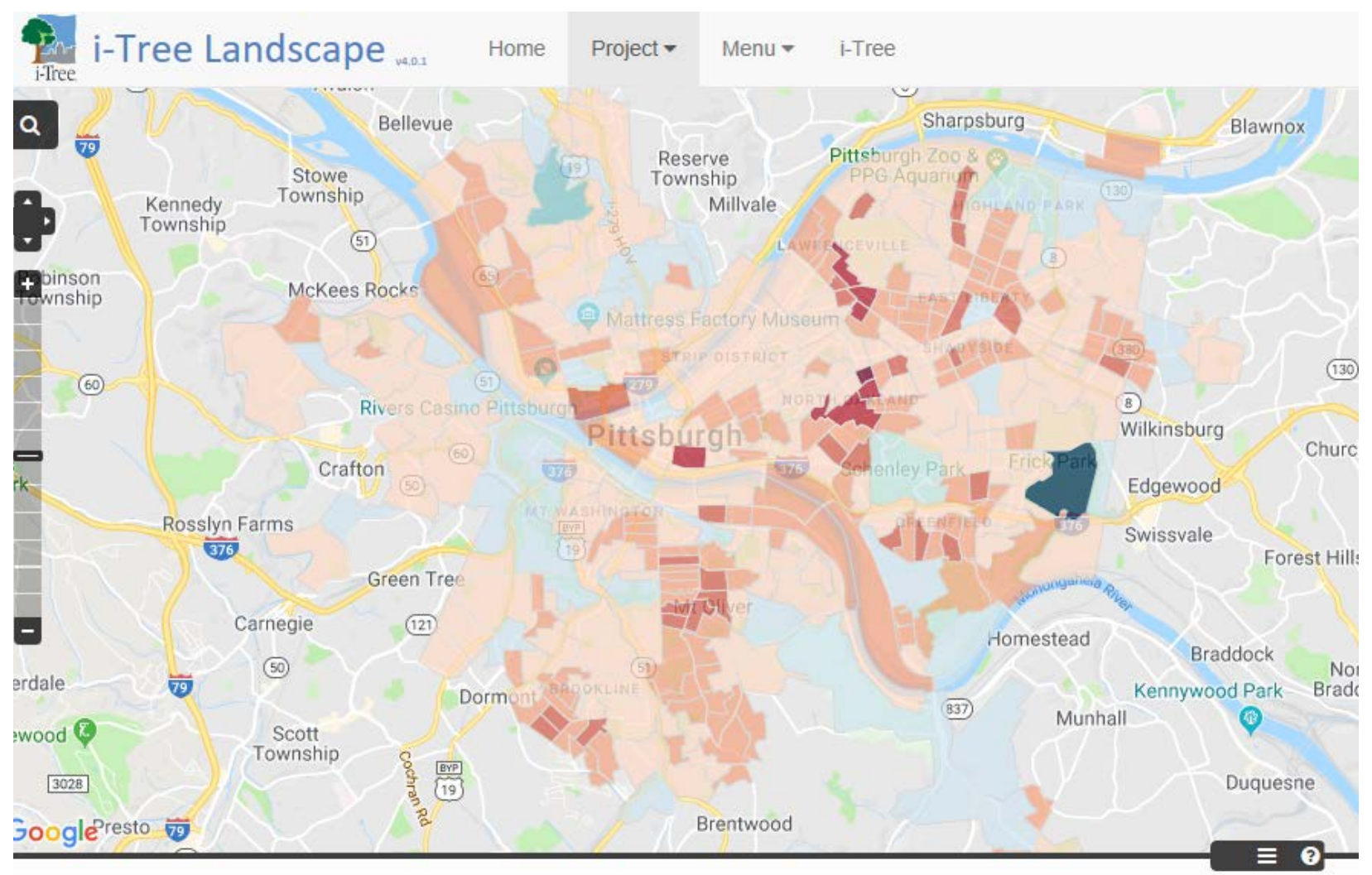

\section{Legend}

\section{Minimum to Maximum}

Figure 18: Areas to Prioritize Plantation

The i-tree landscape gives one a good understanding of the impervious and canopy area sizes, air pollution removal, human health risk information and forest data via exploring Pittsburgh neighborhoods. It also gave areas to prioritize planting of trees, the watercourses of National Hydrology Database that are impaired according to the Environmental Protection Agency (EPA). A location will be determined from the areas where tree plantation is majorly required based on some certain criteria. 


\subsection{Determining the Focus Area}

The i-Tree landscape model result in figure 19 above gave one an idea of places to prioritize green infrastructure. For me to determine the right place to focus my design proposal and evaluations, I randomly chose two neighborhoods from the maximum areas where tree planting is required. I used the i-Tree Landscape model to further analyze the two neighborhoods: North Oakland (Area A) and Lawrenceville (Area B) with some criteria to concentrate on one.

\begin{tabular}{|c|c|c|}
\hline Selection Criteria & Area A & Area B \\
\hline $50 \%$ Impervious & $\checkmark$ & \\
\hline Areas above 500 acres & $\checkmark$ & \\
\hline $30 \%$ Tree Cover Per Capita & $\checkmark$ & $\checkmark$ \\
\hline $40 \%$ Population Density & $\checkmark$ & $\checkmark$ \\
\hline $30 \%$ Tree Stocking Level & $\checkmark$ & $\checkmark$ \\
\hline
\end{tabular}

Table 5: Selection criteria for design focus area 


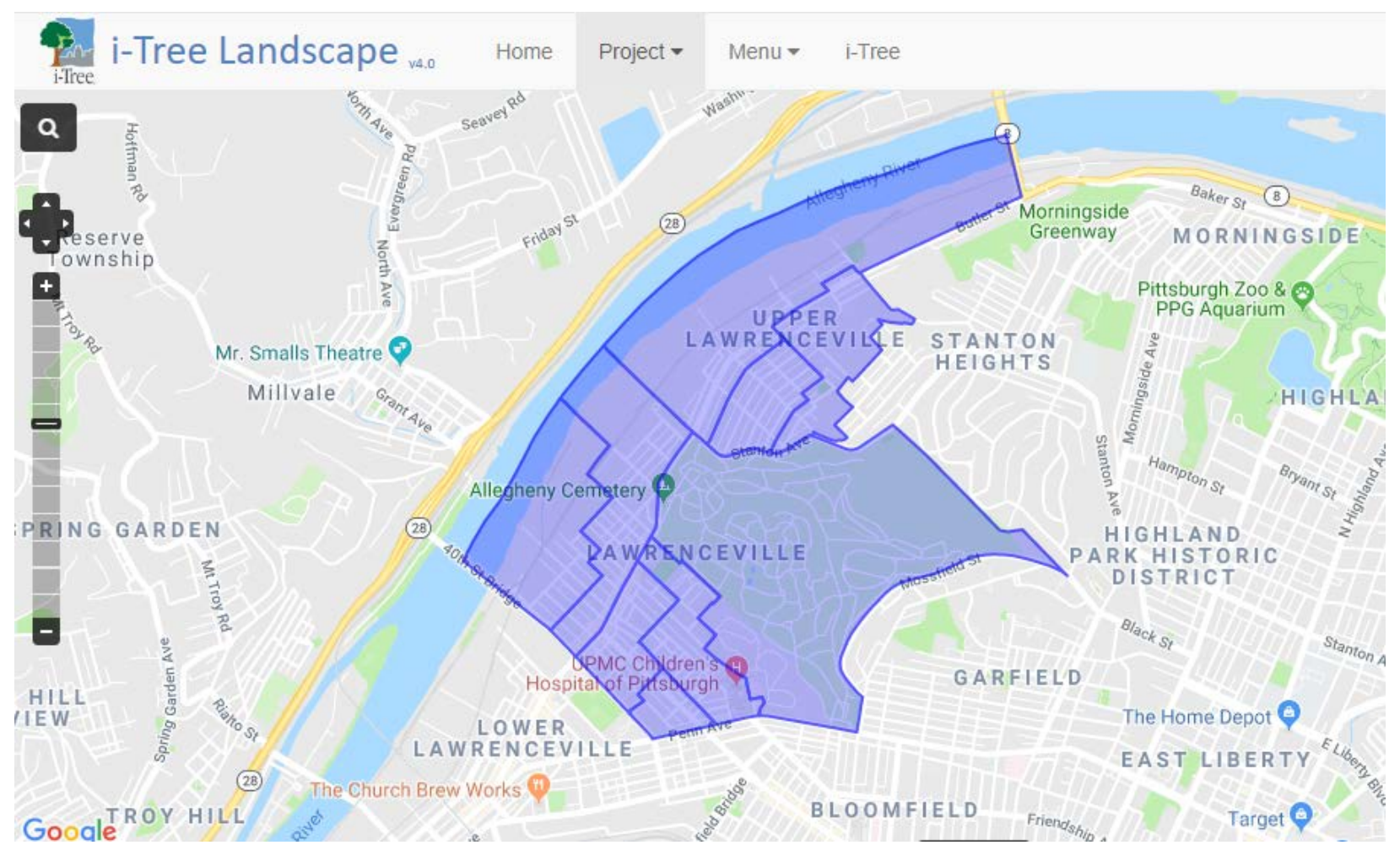

Figure 20: Lawrenceville PA (Area A)

\begin{tabular}{|l|l|l|l|l|l|l|l|l|}
\hline $\begin{array}{l}\text { Canopy \& } \\
\text { Impervious }\end{array}$ & \multicolumn{2}{|l|}{ Area } & \multicolumn{2}{|l|}{ Canopy } & \multicolumn{2}{l|}{ Impervious } & \multicolumn{2}{l|}{ Plantable Space } \\
\cline { 2 - 9 } & Acre & Percentage & Acre & Percentage & Acre & Percentage & Acre & Percentage \\
\hline $\begin{array}{l}\text { Selection } \\
\text { Total }\end{array}$ & 986.5 & 100.00 & 266.0 & 30.40 & 445.9 & 50.96 & 165.5 & 18.91 \\
\hline
\end{tabular}

Table 6: Canopy, Impervious, and Plantable Spaces for Lawrenceville

\begin{tabular}{|l|l|l|l|l|l|l|l|l|}
\hline \multirow{2}{*}{$\begin{array}{l}\text { Canopy \& } \\
\text { Impervious }\end{array}$} & \multicolumn{3}{|l|}{ Carbon Storage } & \multicolumn{2}{l|}{$\begin{array}{l}\text { Carbon } \\
\text { Sequestration }\end{array}$} & \multicolumn{2}{l|}{$\begin{array}{l}\text { Co2 Equivalent } \\
\text { Storage }\end{array}$} & \multicolumn{2}{l|}{$\begin{array}{l}\text { Co2 Equivalent } \\
\text { Sequestration }\end{array}$} \\
\cline { 2 - 9 } & $\$$ & Short Ton & $\$ /$ /yr. & t/yr. & $\$$ & Short Ton & $\$ / y$ r. & t/yr. \\
\hline $\begin{array}{l}\text { Selection } \\
\text { Total }\end{array}$ & 954,855 & $5,598.6$ & 15,642 & 91.7 & 954,804 & $20,528.5$ & 15,642 & 336.3 \\
\hline
\end{tabular}

Table 7: Carbon and $\mathrm{CO}_{2}$ Storage and Sequestration for Lawrenceville 


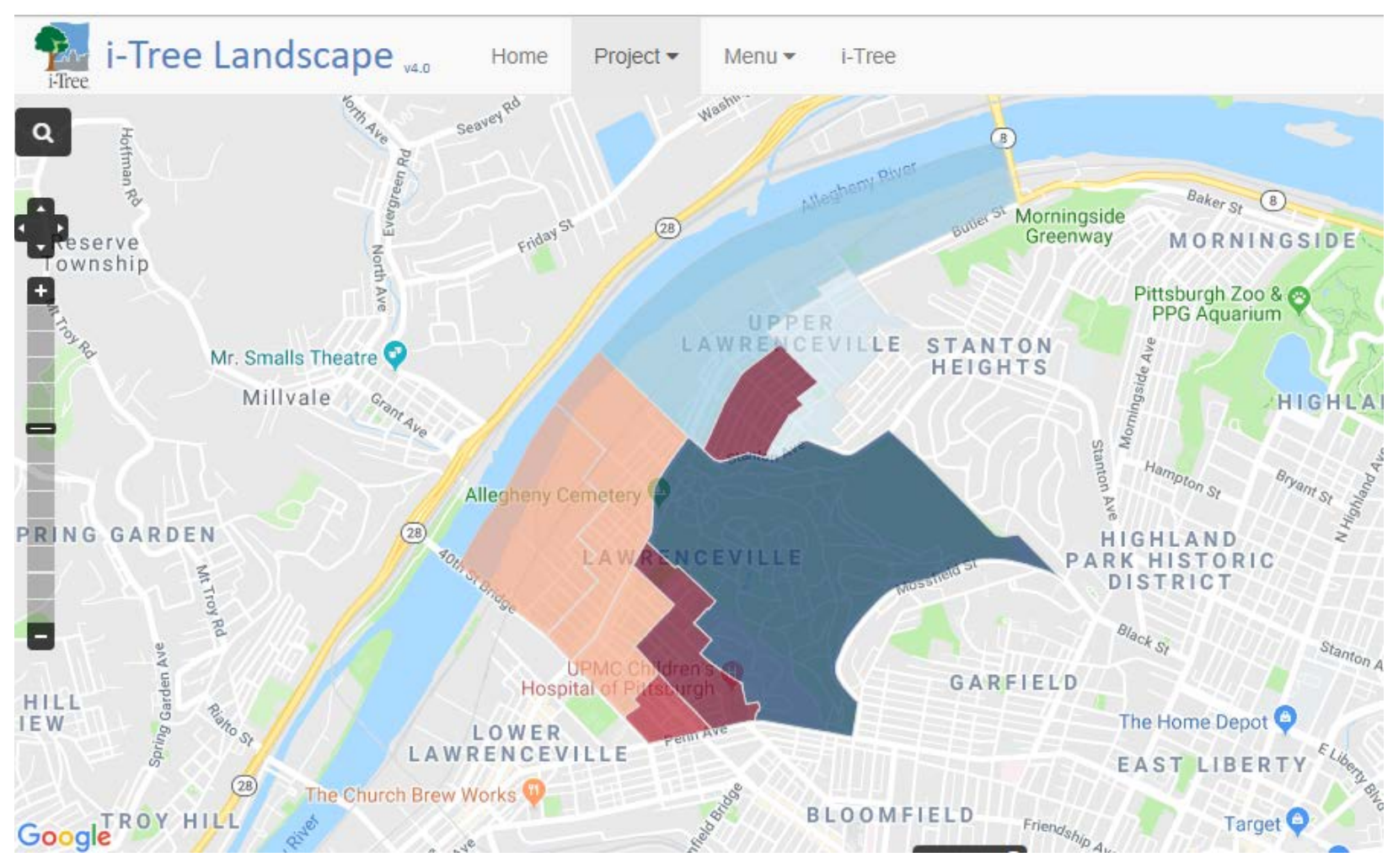

Legend: Min. to Max.

Figure 21: Areas to Prioritize Plantation in Lawrenceville, PA 


\section{Second Option: North Oakland}

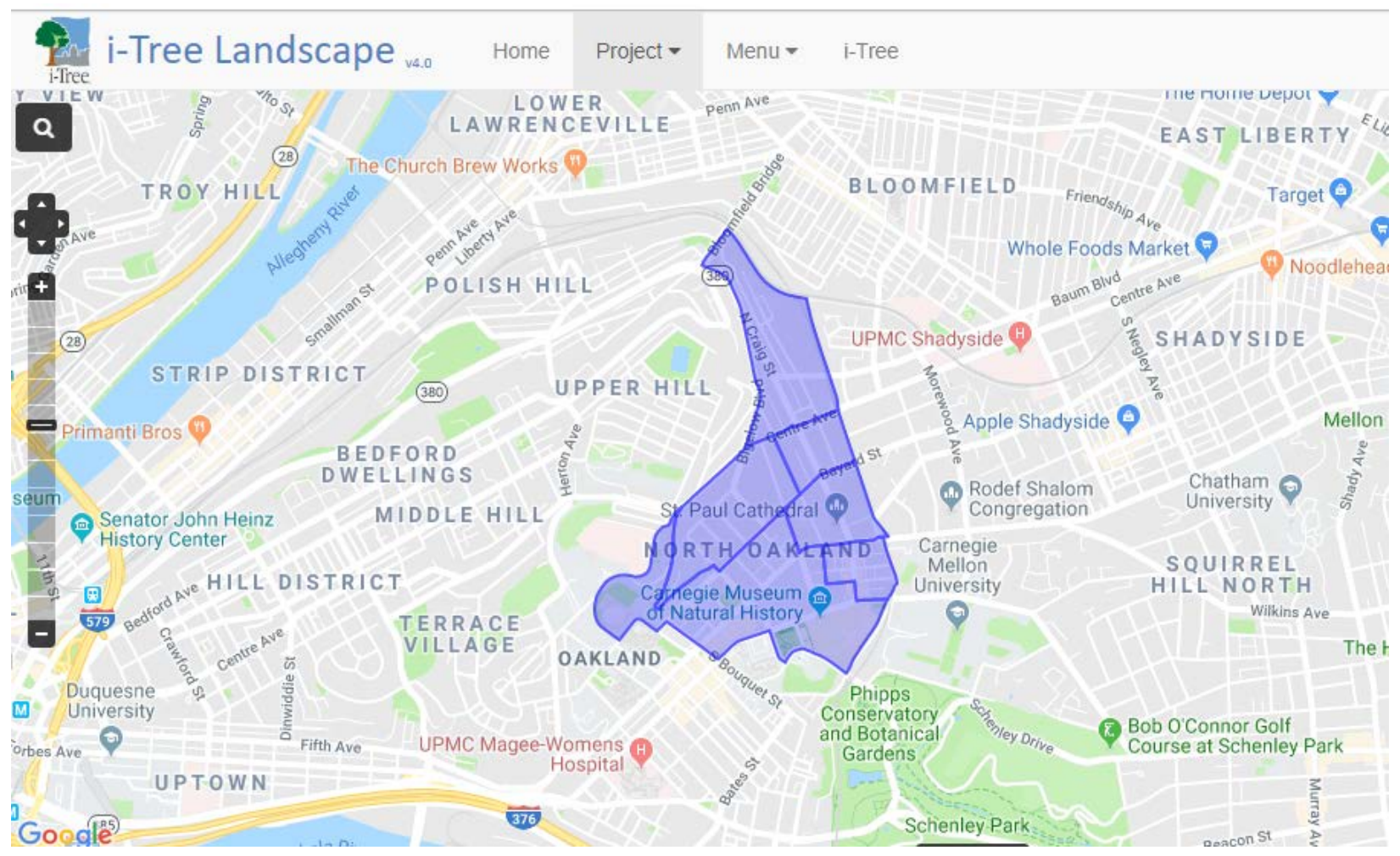

Figure 22: North Oakland Map

\begin{tabular}{|l|l|l|l|l|l|l|l|l|}
\hline \multirow{2}{*}{$\begin{array}{l}\text { Canopy \& } \\
\text { Impervious }\end{array}$} & \multicolumn{2}{|l|}{ Area } & \multicolumn{2}{l|}{ Canopy } & \multicolumn{2}{l|}{ Impervious } & \multicolumn{2}{l|}{ Plantable Space } \\
\cline { 2 - 9 } & Acre & Percentage & Acre & Percentage & Acre & Percentage & Acre & Percentage \\
\hline $\begin{array}{l}\text { Selection } \\
\text { Total }\end{array}$ & 319.3 & 100.00 & 88.5 & 27.71 & 206.3 & 64.61 & 24.5 & 7.68 \\
\hline
\end{tabular}

Table 8: Canopy, Impervious, and Plantable Spaces Table for North Oakland

\begin{tabular}{|c|c|c|c|c|c|c|c|c|}
\hline \multirow{2}{*}{$\begin{array}{l}\text { Canopy \& } \\
\text { Impervious }\end{array}$} & \multicolumn{2}{|c|}{ Carbon Storage } & \multicolumn{2}{|c|}{$\begin{array}{l}\text { Carbon } \\
\text { Sequestration }\end{array}$} & \multicolumn{2}{|c|}{$\begin{array}{l}\mathrm{Co}_{2} \text { Equivalent } \\
\text { Storage }\end{array}$} & \multicolumn{2}{|c|}{$\begin{array}{l}\mathrm{Co}_{2} \text { Equivalent } \\
\text { Sequestration }\end{array}$} \\
\hline & $\$$ & Short Ton & $\$ / y r$. & t/yr. & $\$$ & Short Ton & $\$ / y r$. & t/yr. \\
\hline $\begin{array}{l}\text { Selection } \\
\text { Total }\end{array}$ & 216,584 & $1,269.9$ & 6,422 & 37.7 & 216,573 & $4,656.4$ & 6,422 & 138.0 \\
\hline
\end{tabular}

Table 9: Carbon Results of North Oakland 


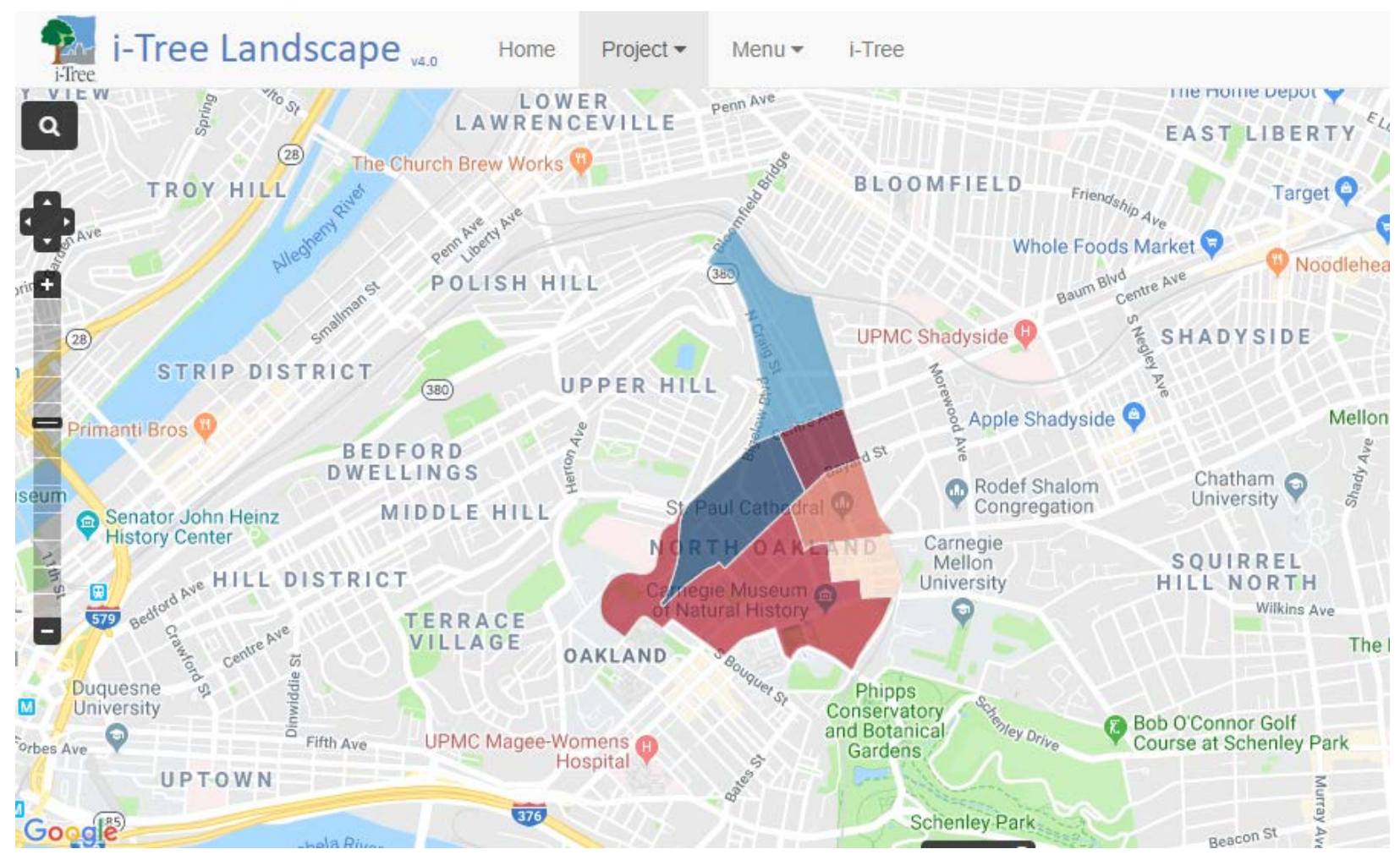

Legend: Min. to Max.

Figure 23: Areas to Prioritize Plantation in North Oakland

Finally, Area A was chosen as the site to propose design intervention and analysis over Area $B$ because Lawrenceville passed all the selection criteria set for decision making (50\% Impervious, Areas above 500 acres, 30\% Tree Cover Per Capita, 40\% Population Density, 30\% Tree Stocking Level). More so, Lawrenceville has more room for growth and development without much design constraints. Lawrenceville is divided into 3 upper Lawrenceville, Central Lawrenceville, and Lower Lawrenceville, though it is seen as an entity. I further chose the Upper Lawrenceville as a pilot project for the whole Lawrenceville, the whole boundary of Upper Lawrenceville was used though not completely highlighted by the i-Tree Landscape result in figure 21 but it was added to address the flood zone challenge as mapped in figure 34 below. 


\section{5. i-Tree Design Model}

$\mathrm{i}$-Tree Design is a model that guide anyone in determining the tree benefits which includes air quality enhancement, stormwater interference, economic, and green gas reduction, through inserting the set location, tree species, conditions, and tree size. The model is used by directly placing the selected specie/s of tree/s to the exact spatial location to get the overall tree benefits (stormwater, air quality, and $\mathrm{CO}_{2}$ ) for 2 to 99 years.

After having an idea on the area to focus on prioritizing tree planting, i-Tree Design v6.0 was used as the third model to get an estimation of the different benefits of the individual trees, by also making a pre and post comparism of the existing condition and my 5 design patterns which include Parks, Waterfront, Activity Nodes, Green Streets, and Green Parking looking at a 10 -year plan benefits of the both conditions. Different trees samples; Red elm (Ulmus rubra), American Mountain ash (Sorbus Americana), Eastern Hemlock (Tsuga canadensis), Balsam fir (Albies balsamea), Ironwood (Ostrya virginiana), and Hickory trees were used in the design model. It was done through these processes:

1. Entering a street address of sample area among the areas to prioritize plantation with a choice of determining areas where trees have an effect on heating and cooling utility on a building.

2. Placing the trees by describing the tree species, diameter or circumference, tree condition, tree exposure to sunlight and finally dragging the trees in the areas that need intervention by zooming in and out.

3. Lastly estimating the benefits of the trees planted by entering the number of years from 2 to 99 to calculate overall benefits on the amount of money to be saved on stormwater, air quality and $\mathrm{CO} 2$; stormwater - the amount of gallons of stormwater to intercept; energy - ; air quality - on the chart showing the absorbing pollutants, intercepting particulate; and carbon Dioxide - the pounds of carbon dioxide those trees will reduce. 


\section{i-Tree Design Model Results}

The results for the five design patterns were explored according to their location and provided below to have a good understanding about stormwater runoff savings, air quality improvement savings, number of gallons of rainfall intercepted, and carbon dioxide reduction savings provided below.

Address: 27 51st St. Pittsburgh, PA, 15201, USA

Trees Evaluated $=60$

\begin{tabular}{|c|c|}
\hline $\begin{array}{lllll}\begin{array}{l}\text { Current } \\
\text { Benefits }\end{array} & & & & \\
\text { Bear } 2019 & \text { i-Tree } & \text { Design } \\
\end{array}$ & Tot \\
\hline $\begin{array}{l}\$ 1,287.20 \text { of stormwater runoff savings by } \\
\text { intercepting } 160,903 \text { gallons of rainfall. }\end{array}$ & intercepting $8,856,730$ gallons of rainfall. \\
\hline $\begin{array}{l}\$ 164.17 \text { of air quality improvement } \\
\text { savings }\end{array}$ & $\$ 9,333$ of air qualit) \\
\hline $\begin{array}{l}\$ 169.26 \text { of carbon dioxide reduction } \\
\text { savings }\end{array}$ & $\begin{array}{l}\$ 8,837 \text { of carbon dioxide reduction } \\
\text { savings }\end{array}$ \\
\hline
\end{tabular}

Table 10: Pre- Condition Results of Upper Lawrenceville Park Site

Trees Evaluated $=279$

\begin{tabular}{|l|l|}
\hline $\begin{array}{l}\text { Current Year 2019 i-Tree Design } \\
\text { Benefits }\end{array}$ & Total 10 - Year Benefits (2029) \\
\hline $\begin{array}{l}\$ 6,013.43 \text { of stormwater runoff savings by } \\
\text { intercepting } 751,671 \text { gallons of rainfall. }\end{array}$ & $\begin{array}{l}\$ 275,290 \text { of stormwater runoff savings by } \\
\text { intercepting } 34,410,361 \text { gallons of rainfall. }\end{array}$ \\
\hline $\begin{array}{l}\$ 829.25 \text { of air quality improvement } \\
\text { savings }\end{array}$ & $\begin{array}{l}\$ 41,719 \text { of air quality improvement } \\
\text { savings }\end{array}$ \\
\hline $\begin{array}{l}\$ 949.69 \text { of carbon dioxide reduction } \\
\text { savings }\end{array}$ & $\begin{array}{l}\$ 34,155 \text { of carbon dioxide reduction } \\
\text { savings }\end{array}$ \\
\hline
\end{tabular}

Table 11: 10-Year Post Benefits Results of Upper Lawrenceville Park 
Address: 5125 Holmes St. Pittsburgh, PA 15201, USA

Trees Evaluated $=44$

\begin{tabular}{|c|c|}
\hline $\begin{array}{lllll}\begin{array}{l}\text { Current } \\
\text { Benefits }\end{array} & & & & \\
\text { Bear } 2019 & \text { i-Tree } & \text { Design } \\
\end{array}$ & Total $10-\mathrm{Ye}$ \\
\hline $\begin{array}{l}\$ 900.68 \text { of stormwater runoff savings by } \\
\text { intercepting } 112,580 \text { gallons of rainfall. }\end{array}$ & $\begin{array}{l}\$ 34,287 \text { of stormwater runoff savings by } \\
\text { intercepting } 4,285,983 \text { gallons of rainfall. }\end{array}$ \\
\hline $\begin{array}{l}\$ 106.32 \text { of air quality improvement } \\
\text { savings }\end{array}$ & $\$ 4,023$ of air quality improvement savings \\
\hline $\begin{array}{l}\$ 131.76 \text { of carbon dioxide reduction } \\
\text { savings }\end{array}$ & $\begin{array}{l}\$ 5,078 \text { of carbon dioxide reduction } \\
\text { savings }\end{array}$ \\
\hline
\end{tabular}

Table 12: Pre- Condition Results of Recreational Park Site

Trees Evaluated $=232$

\begin{tabular}{|l|l|}
\hline $\begin{array}{l}\text { Current Year 2019 i-Tree Design } \\
\text { Benefits }\end{array}$ & Total 10 - Year Benefits (2029) \\
\hline $\begin{array}{l}\$ 3,657.62 \text { of stormwater runoff savings by } \\
\text { intercepting } 457,170 \text { gallons of rainfall. }\end{array}$ & $\begin{array}{l}\$ 134,471 \text { of stormwater runoff savings by } \\
\text { intercepting } 16,808,751 \text { gallons of rainfall. }\end{array}$ \\
\hline $\begin{array}{l}\$ 657.08 \text { of air quality improvement } \\
\text { savings }\end{array}$ & $\begin{array}{l}\$ 24,168 \text { of air quality improvement } \\
\text { savings }\end{array}$ \\
\hline $\begin{array}{l}\$ 425.64 \text { of carbon dioxide reduction } \\
\text { savings }\end{array}$ & $\begin{array}{l}\$ 18,062 \text { of carbon dioxide reduction } \\
\text { savings }\end{array}$ \\
\hline
\end{tabular}

Table 13: 10-Year Post Benefits Results of Recreational Park 
Address: 6111 Butler St. Pittsburgh, PA 15201, USA

Trees Evaluated $=40$

\begin{tabular}{|c|c|}
\hline $\begin{array}{lllll}\begin{array}{l}\text { Current } \\
\text { Benefits }\end{array} & & & & \\
\text { Bear } 2019 & \text { i-Tree } & \text { Design } \\
\end{array}$ & Total 10 \\
\hline $\begin{array}{l}\$ 869.04 \text { of stormwater runoff savings by } \\
\text { intercepting } 108,617 \text { gallons of rainfall. }\end{array}$ & $\begin{array}{l}\$ 45,375 \text { of stormwater runoff savings by } \\
\text { intercepting } 5,671,910 \text { gallons of rainfall. }\end{array}$ \\
\hline $\begin{array}{l}\$ 105.88 \text { of air quality improvement } \\
\text { savings }\end{array}$ & $\$ 5,599$ of air quality improvement savings \\
\hline $\begin{array}{l}\$ 113.40 \text { of carbon dioxide reduction } \\
\text { savings }\end{array}$ & $\begin{array}{l}\$ 5,279 \text { of carbon dioxide reduction } \\
\text { savings }\end{array}$ \\
\hline
\end{tabular}

Table 14: Pre- Condition Results of Outdoor Event Center.

Trees Evaluated $=602$

\begin{tabular}{|l|l|}
\hline $\begin{array}{l}\text { Current Year 2019 i-Tree Design } \\
\text { Benefits }\end{array}$ & Total 10 - Year Benefits (2029) \\
\hline $\begin{array}{l}\$ 15,022.57 \text { of stormwater runoff savings } \\
\text { by intercepting } 1,877,937 \text { gallons of } \\
\text { rainfall. }\end{array}$ & $\begin{array}{l}\$ 954,263 \text { of stormwater runoff savings by } \\
\text { intercepting } 119,280,974 \text { gallons of } \\
\text { rainfall. }\end{array}$ \\
\hline $\begin{array}{l}\$ 2,275.51 \text { of air quality improvement } \\
\text { savings }\end{array}$ & $\begin{array}{l}\$ 155,322 \text { of air quality improvement } \\
\text { savings }\end{array}$ \\
\hline $\begin{array}{l}\$ 1,731.39 \text { of carbon dioxide reduction } \\
\text { savings }\end{array}$ & $\begin{array}{l}\$ 84,536 \text { of carbon dioxide reduction } \\
\text { savings }\end{array}$ \\
\hline
\end{tabular}

Table 15: 10-Year Post Benefits Results of Outdoor Event Center 
Address: 520 McCandless Ave. Pittsburgh, PA 15201, USA

Trees Evaluated $=11$ each for the 3 Nodes

\begin{tabular}{|l|l|}
\hline $\begin{array}{l}\text { Current Year 2019 i-Tree Design } \\
\text { Benefits }\end{array}$ & Total 10 - Year Benefits (2019) \\
\hline $\begin{array}{l}\$ 629.31 \text { of stormwater runoff savings by } \\
\text { intercepting } 78,663 \text { gallons of rainfall. }\end{array}$ & $\begin{array}{l}\$ 25,425 \text { of stormwater runoff savings by } \\
\text { intercepting } 3,178,104 \text { gallons of rainfall. }\end{array}$ \\
\hline $\begin{array}{l}\$ 75.9 \text { of air quality improvement savings } \\
\$ 69.15 \text { of carbon dioxide reduction } \\
\text { savings }\end{array}$ & $\begin{array}{l}\$ 3,159 \text { of carbon dioxide reduction } \\
\text { savings }\end{array}$ \\
\hline
\end{tabular}

Table 16: Pre- Condition Results of the 3 Activity Nodes

Trees Evaluated $=40$ for Each of the 3 Nodes

\begin{tabular}{|l|l|}
\hline $\begin{array}{l}\text { Current Year 2019 i-Tree Design } \\
\text { Benefits }\end{array}$ & Total 10 - Year Benefits (2029) \\
\hline $\begin{array}{l}\$ 1,838.64 \text { of stormwater runoff savings by } \\
\text { intercepting } 283,533 \text { gallons of rainfall. }\end{array}$ & $\begin{array}{l}\$ 39,597 \text { of stormwater runoff savings by } \\
\text { intercepting } 4,949,757 \text { gallons of rainfall. }\end{array}$ \\
\hline $\begin{array}{l}\$ 502.56 \text { of air quality improvement } \\
\text { savings }\end{array}$ & $\begin{array}{l}\$ 48,510 \text { of air quality improvement } \\
\text { savings }\end{array}$ \\
\hline $\begin{array}{l}\$ 349.71 \text { of carbon dioxide reduction } \\
\text { savings }\end{array}$ & $\begin{array}{l}\$ 7,890 \text { of carbon dioxide reduction } \\
\text { savings }\end{array}$ \\
\hline
\end{tabular}

Table17: 10-Year Post Benefits Results for the 3 Activity Nodes

Address: 5629 Harrison St. Pittsburgh, PA 15201, USA

Trees Evaluated $=100$

\begin{tabular}{|lllll|l}
\hline $\begin{array}{l}\text { Current } \\
\text { Benefits }\end{array}$ & Year 2019 & i-Tree & Design & Total 10 - Year Benefits (2029) \\
Ben & & & \\
\hline
\end{tabular}




\begin{tabular}{|l|l|l|}
\hline $\begin{array}{l}\$ 1,569.16 \text { of stormwater runoff savings by } \\
\text { intercepting } 196,105 \text { gallons of rainfall. }\end{array}$ & $\begin{array}{l}\$ 99,985 \text { of stormwater runoff savings by } \\
\text { intercepting } 12,497,786 \text { gallons of rainfall. }\end{array}$ \\
\hline $\begin{array}{l}\$ 222.16 \text { of air quality improvement } \\
\text { savings }\end{array}$ & $\begin{array}{l}\$ 14,602 \text { of air quality improvement } \\
\text { savings }\end{array}$ \\
\hline $\begin{array}{l}\$ 107.92 \text { of carbon dioxide reduction } \\
\text { savings }\end{array}$ & $\begin{array}{l}\$ 6,916 \text { of carbon dioxide reduction } \\
\text { savings }\end{array}$ \\
\hline
\end{tabular}

Table 18: Pre- Condition Results of Green Parking

Trees Evaluated $=341$

\begin{tabular}{|l|l|}
\hline $\begin{array}{l}\text { Current Year 2019 i-Tree Design } \\
\text { Benefits }\end{array}$ & Total 10 - Year Benefits (2029) \\
\hline $\begin{array}{l}\$ 6,835.96 \text { of stormwater runoff savings by } \\
\text { intercepting } 854,494 \text { gallons of rainfall. }\end{array}$ & $\begin{array}{l}\$ 413,965 \text { of stormwater runoff savings by } \\
\text { intercepting } 51,744,402 \text { gallons of rainfall. }\end{array}$ \\
\hline $\begin{array}{l}\$ 1,047.65 \text { of air quality improvement } \\
\text { savings }\end{array}$ & $\begin{array}{l}\$ 66,031 \text { of air quality improvement } \\
\text { savings }\end{array}$ \\
\hline $\begin{array}{l}\$ 1,247.12 \text { of carbon dioxide reduction } \\
\text { savings }\end{array}$ & $\begin{array}{l}\$ 65,224 \text { of carbon dioxide reduction } \\
\text { savings }\end{array}$ \\
\hline
\end{tabular}

Tables 19: 10-Year Post Benefits Results of Green Parking

Address: 5147 Keystone St. Pittsburgh, PA 15201, USA

Trees Evaluated $=8$ each for 30 Streets

\begin{tabular}{|c|c|}
\hline $\begin{array}{lllll}\text { Current } & \text { Year } 2019 & \text { i-Tree } & \text { Design } \\
\text { Benefits } & & & & \\
\end{array}$ & Total 10 - Year Benefits (2029) \\
\hline $\begin{array}{l}\$ 2,946.9 \text { of stormwater runoff savings by } \\
\text { intercepting } 368,280 \text { gallons of rainfall. }\end{array}$ & $\begin{array}{l}\$ 235,590 \text { of stormwater runoff savings by } \\
\text { intercepting } 2,944,785 \text { gallons of rainfall. }\end{array}$ \\
\hline$\$ 575.7$ of air quality improvement savings & $\begin{array}{l}\$ 44,460 \text { of air quality improvement } \\
\text { savings }\end{array}$ \\
\hline
\end{tabular}




\begin{tabular}{|l|l|lll|l}
\hline $\begin{array}{l}\$ 180.9 \\
\text { savings }\end{array}$ & carbon dioxide reduction & $\begin{array}{l}\$ 22230 \\
\text { savings }\end{array}$ & of carbon dioxide reduction \\
\hline
\end{tabular}

Table 20: Pre- Condition Results of 30 Green Streets

Trees Evaluated $=40$ each for 30 streets

\begin{tabular}{|l|l|}
\hline $\begin{array}{l}\text { Current Year 2019 i-Tree Design } \\
\text { Benefits }\end{array}$ & Total 10 - Year Benefits (2029) \\
\hline $\begin{array}{l}\$ 22,682.40 \text { of stormwater runoff savings } \\
\text { by intercepting 2,835,330 gallons of } \\
\text { rainfall. }\end{array}$ & $\begin{array}{l}\$ 2,370,330 \text { of stormwater runoff savings } \\
\text { by intercepting 296,290,770 gallons of } \\
\text { rainfall. }\end{array}$ \\
\hline $\begin{array}{l}\$ 5025.60 \text { of air quality improvement } \\
\text { savings }\end{array}$ & $\begin{array}{l}\$ 485,100 \text { of air quality improvement } \\
\text { savings }\end{array}$ \\
\hline $\begin{array}{l}\$ 1516.8 \text { of carbon dioxide reduction } \\
\text { savings }\end{array}$ & $\begin{array}{l}\$ 173,730 \text { of carbon dioxide reduction } \\
\text { savings }\end{array}$ \\
\hline
\end{tabular}

Tables 21: 10-Year Post Benefits Results of 30 Green Streets

Address: 5629 Harrison St. Pittsburgh, PA 15201, USA

Trees Evaluated $=100$

\begin{tabular}{|l|l|}
\hline $\begin{array}{l}\text { Current Year 2019 i-Tree Design } \\
\text { Benefits }\end{array}$ & Total 10 - Year Benefits (2029) \\
\hline $\begin{array}{l}\text { \$1,569.16 of stormwater runoff savings by } \\
\text { intercepting } 196,105 \text { gallons of rainfall. }\end{array}$ & $\begin{array}{l}\$ 99,985 \text { of stormwater runoff savings by } \\
\text { intercepting } 12,497,786 \text { gallons of rainfall. }\end{array}$ \\
\hline $\begin{array}{l}\$ 222.16 \text { of air quality improvement } \\
\text { savings }\end{array}$ & $\begin{array}{l}\$ 14,602 \text { of air quality improvement } \\
\text { savings }\end{array}$ \\
\hline $\begin{array}{l}\$ 107.92 \text { of carbon dioxide reduction } \\
\text { savings }\end{array}$ & $\begin{array}{l}\$ 6,916 \text { of carbon dioxide reduction } \\
\text { savings }\end{array}$ \\
\hline
\end{tabular}

Table 22: Pre- Condition Results of Riverfront 
Trees Evaluated $=226$

\begin{tabular}{|l|l|}
\hline $\begin{array}{l}\text { Current Year 2019 i-Tree Design } \\
\text { Benefits }\end{array}$ & Total 10 - Year Benefits (2029) \\
\hline $\begin{array}{l}\$ 3,434.11 \text { of stormwater runoff savings by } \\
\text { intercepting } 429,202 \text { gallons of rainfall. }\end{array}$ & $\begin{array}{l}\$ 283,434 \text { of stormwater runoff savings by } \\
\text { intercepting } 34,427,948 \text { gallons of rainfall. }\end{array}$ \\
\hline $\begin{array}{l}\$ 512.63 \text { of air quality improvement } \\
\text { savings }\end{array}$ & $\begin{array}{l}\$ 43,781 \text { of air quality improvement } \\
\text { savings }\end{array}$ \\
\hline $\begin{array}{l}\$ 339.29 \text { of carbon dioxide reduction } \\
\text { savings }\end{array}$ & $\begin{array}{l}\$ 19,460 \text { of carbon dioxide reduction } \\
\text { savings }\end{array}$ \\
\hline
\end{tabular}

Tables 23: 10-Year Post Benefits Results of Riverfront

The i-Tree Design model exposes one to the economic and environmental benefits that can be maximized if the interventions are applied. The pre (existing) and post (10 years) evaluations were processed to see the benefits one can derive. The tree counting of the existing trees were made by aerial view of the site. To summarize the overall benefits of the interventions we will be looking at them under 5 patterns: Green Parks, Activity Nodes, Green Parking, Green Streets and Riverfront and the pre and post conditions as seen in the tables below.

\begin{tabular}{|c|c|c|c|c|c|}
\hline $\mathrm{S} / \mathrm{N}$ & Patterns & $\begin{array}{l}\text { Total \# } \\
\text { of } \\
\text { Trees }\end{array}$ & Tree Benefits & 2019 & 2029 \\
\hline \multirow[t]{4}{*}{1.} & \multirow{4}{*}{$\begin{array}{l}\text { Green } \\
\text { Parks }\end{array}$} & \multirow[t]{4}{*}{144} & Stormwater runoff savings & $\$ 3056.92$ & $\$ 150,518$ \\
\hline & & & Galloons Intercepted & 382,100 & $18,814,623$ \\
\hline & & & $\begin{array}{l}\text { Air quality improvement } \\
\text { savings }\end{array}$ & $\$ 376.37$ & $\$ 18,955$ \\
\hline & & & $\mathrm{CO}_{2}$ reduction savings & $\$ 414.42$ & $\$ 19,194$ \\
\hline \multirow[t]{2}{*}{2.} & \multirow{2}{*}{$\begin{array}{l}\text { Activity } \\
\text { Nodes }\end{array}$} & \multirow[t]{2}{*}{33} & Stormwater runoff savings & $\$ 629.31$ & $\$ 45,375$ \\
\hline & & & Galloons Intercepted & 78,663 & $3,178,104$ \\
\hline
\end{tabular}




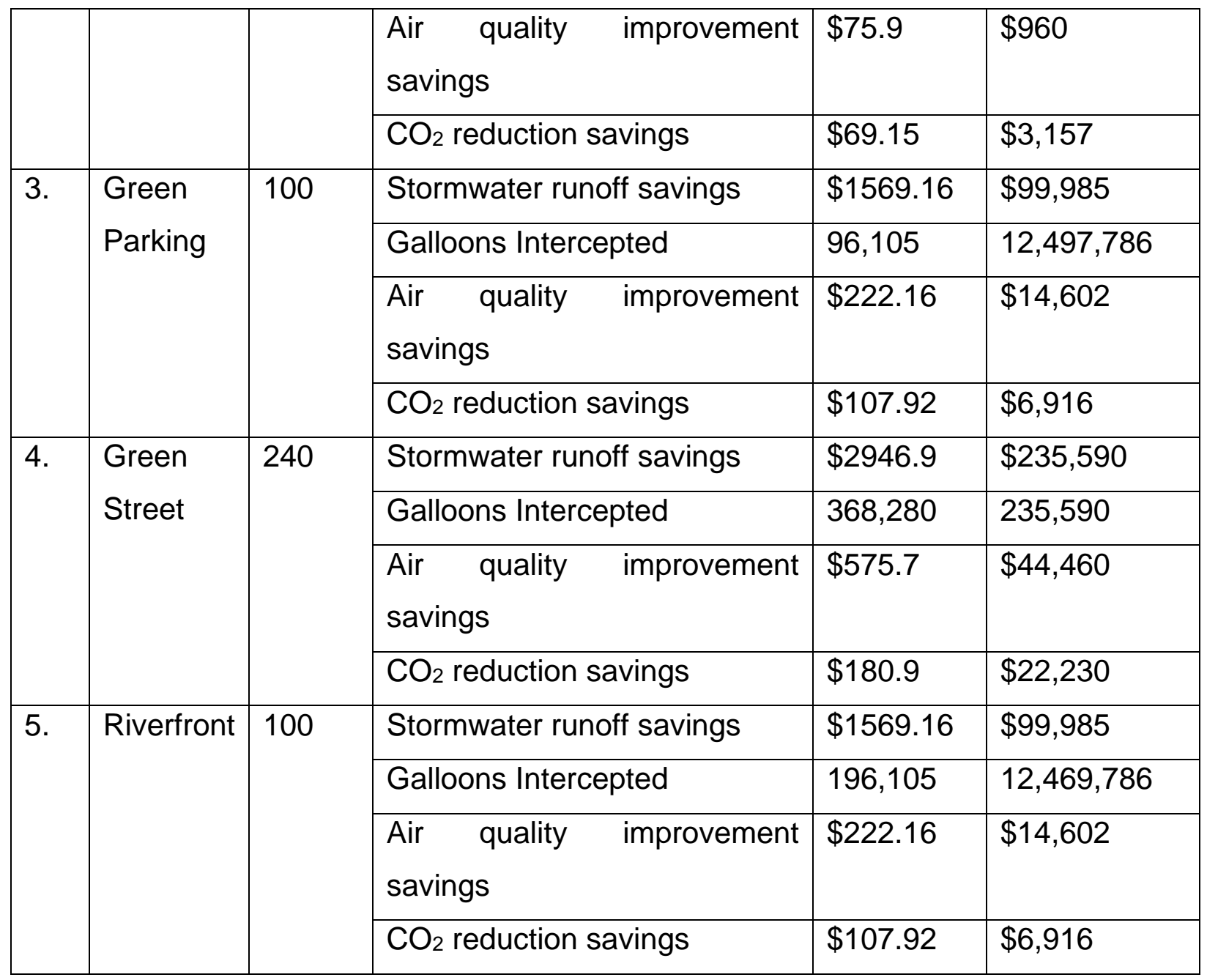

Table 24: Pre-Condition Table of the 5 Design Patterns

\begin{tabular}{|l|l|l|l|l|l|}
\hline S/N & Patterns & $\begin{array}{l}\text { Total } \\
\# \quad \begin{array}{r}\text { of } \\
\text { Trees }\end{array}\end{array}$ & \multicolumn{1}{|c|}{ Tree Benefits } & $\mathbf{2 0 1 9}$ & $\mathbf{2 0 2 9}$ \\
\hline 1. & $\begin{array}{l}\text { Green } \\
\text { Parks }\end{array}$ & 1,113 & Stormwater runoff savings & $\$ 24,693.62$ & $\$ 1,364,024$ \\
\cline { 4 - 6 } & & & $\begin{array}{l}\text { Galloons Intercepted } \\
\text { Air quality improvement } \\
\text { savings }\end{array}$ & $\$ 3,761.84$ & $\$ 221,209$ \\
\cline { 4 - 6 } & & & $\$ 3,778$ reduction savings & $170,500,086$ \\
\hline
\end{tabular}




\begin{tabular}{|c|c|c|c|c|c|}
\hline \multirow[t]{4}{*}{2.} & Activity & \multirow[t]{4}{*}{120} & Stormwater runoff savings & $\$ 1,838.64$ & $\$ 39,597$ \\
\hline & \multirow{3}{*}{ Nodes } & & Galloons Intercepted & 283,533 & $4,949,757$ \\
\hline & & & $\begin{array}{l}\text { Air quality improvement } \\
\text { savings }\end{array}$ & $\$ 502.56$ & $\$ 48,510$ \\
\hline & & & $\mathrm{CO}_{2}$ reduction savings & $\$ 349.71$ & $\$ 7,890$ \\
\hline \multirow[t]{4}{*}{3} & \multirow{4}{*}{$\begin{array}{l}\text { Green } \\
\text { Parking }\end{array}$} & \multirow[t]{4}{*}{341} & Stormwater runoff savings & $\$ 6,835.96$ & $\$ 413,965$ \\
\hline & & & Galloons Intercepted & 854,494 & $51,744,402$ \\
\hline & & & $\begin{array}{l}\text { Air quality improvement } \\
\text { savings }\end{array}$ & $\$ 1,047.65$ & $\$ 65,224$ \\
\hline & & & $\mathrm{CO}_{2}$ reduction savings & $\$ 1,247.12$ & $\$ 65,224$ \\
\hline \multirow[t]{4}{*}{4.} & \multirow{4}{*}{$\begin{array}{l}\text { Green } \\
\text { Street }\end{array}$} & \multirow[t]{4}{*}{1200} & Stormwater runoff savings & $\$ 22,682.40$ & $\$ 2,370,330$ \\
\hline & & & Galloons Intercepted & $2,835,330$ & $296,290,770$ \\
\hline & & & $\begin{array}{l}\text { Air quality improvement } \\
\text { savings }\end{array}$ & $\$ 5,025.60$ & $\$ 485,100$ \\
\hline & & & $\mathrm{CO}_{2}$ reduction savings & $\$ 1,516.80$ & $\$ 173,730$ \\
\hline \multirow[t]{4}{*}{5.} & \multirow[t]{4}{*}{ Riverfront } & \multirow[t]{4}{*}{226} & Stormwater runoff savings & $\$ 3,434.11$ & $\$ 283,434$ \\
\hline & & & Galloons Intercepted & 429,202 & $34,427,948$ \\
\hline & & & $\begin{array}{l}\text { Air quality improvement } \\
\text { savings }\end{array}$ & $\$ 512.63$ & $\$ 43,781$ \\
\hline & & & $\mathrm{CO}_{2}$ reduction savings & $\$ 339.29$ & $\$ 19,460$ \\
\hline
\end{tabular}

Table 25: Post-Condition Table of the 5 Design Patterns 


\section{CHAPTER 4}

\section{Site Inventory}

\subsection{Present Condition}

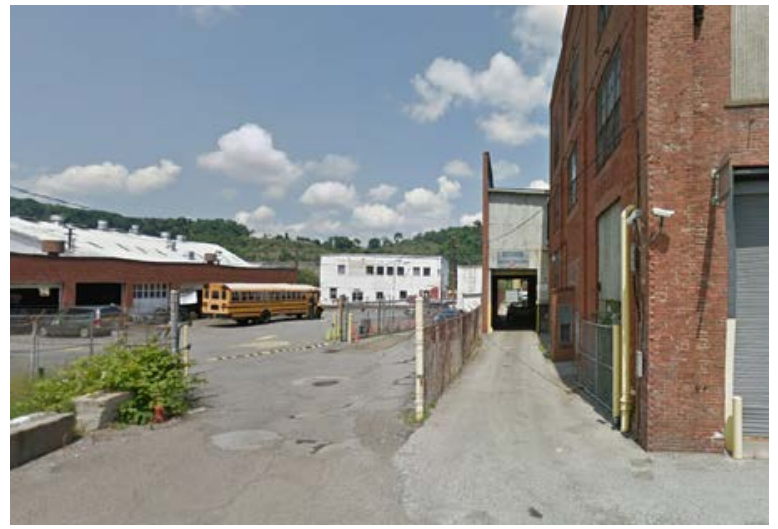

Figure 24: $\mathrm{A} 1$ - Transit Inc

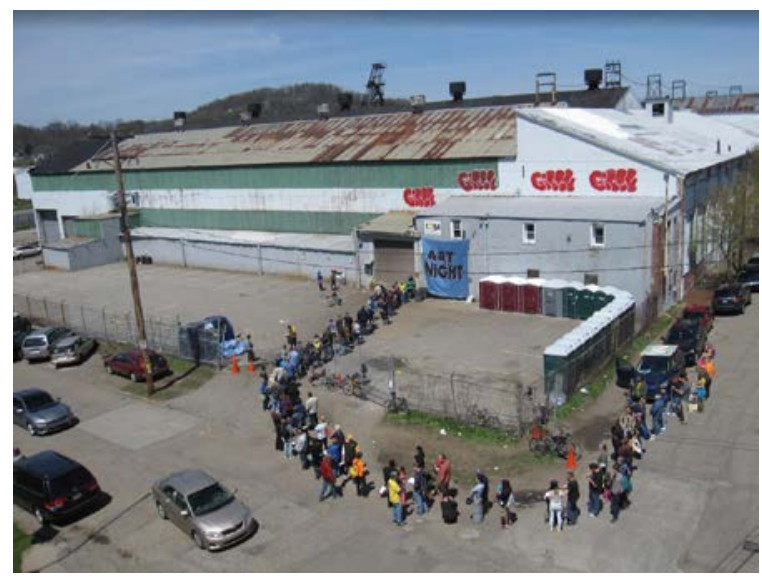

Figure 26: Art All Night Event Area

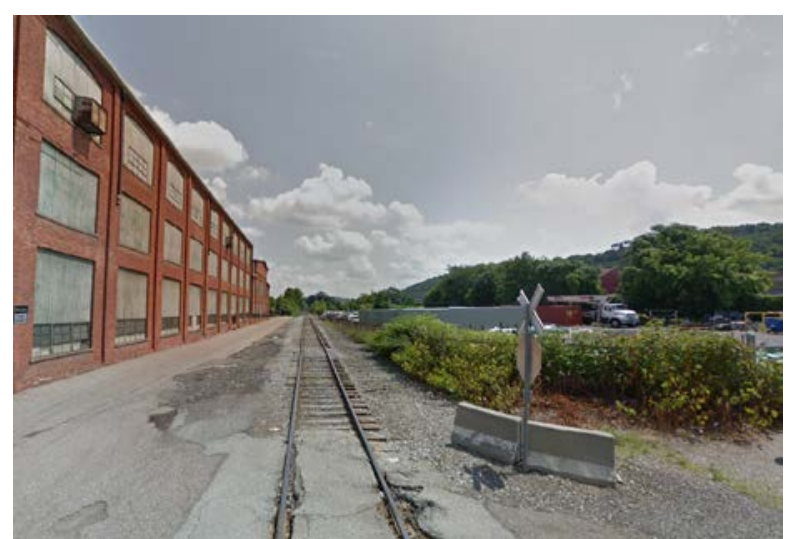

Figure 25: Existing Rail Track

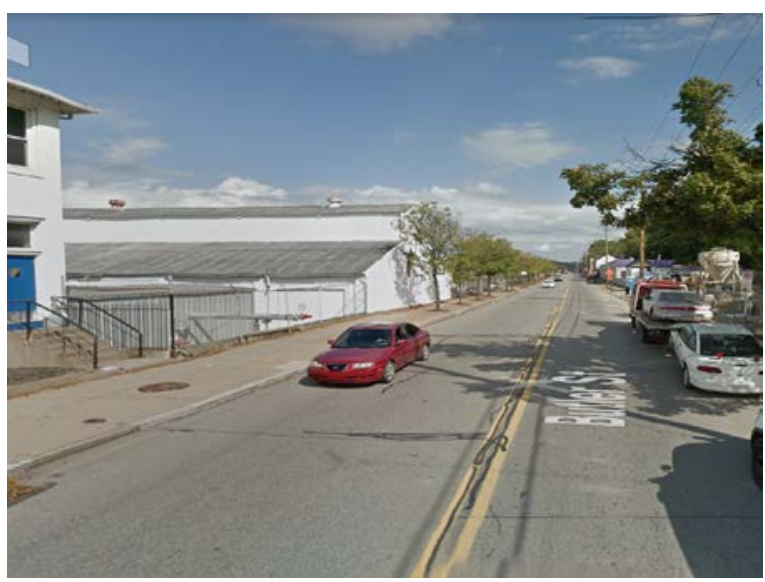

Figure 27: Industrial Area 


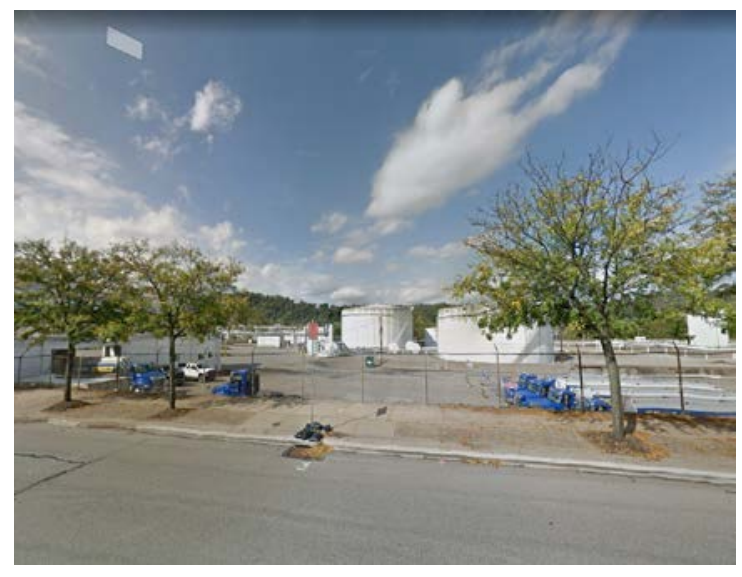

Figure 28: Sunoco Company

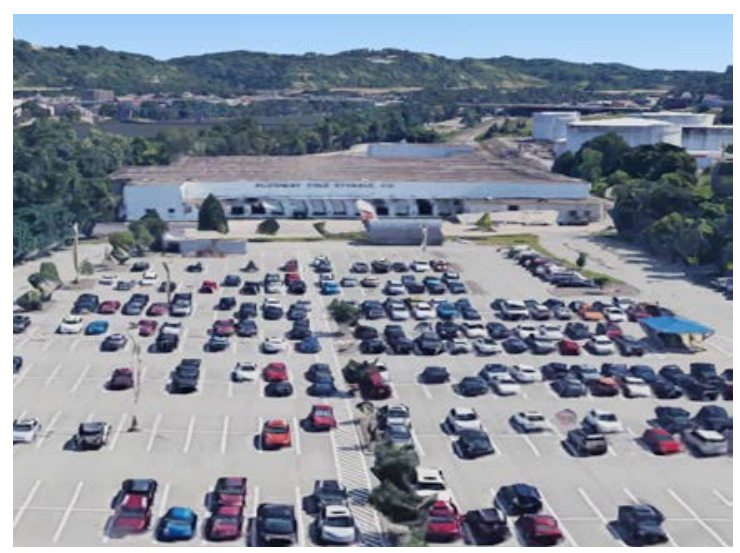

Figure 30: Children Lots Shuttle

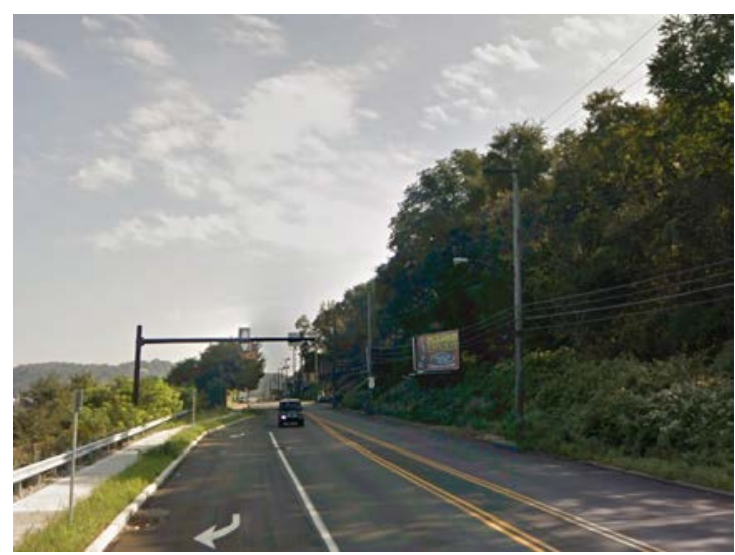

Figure 32: Butler Street

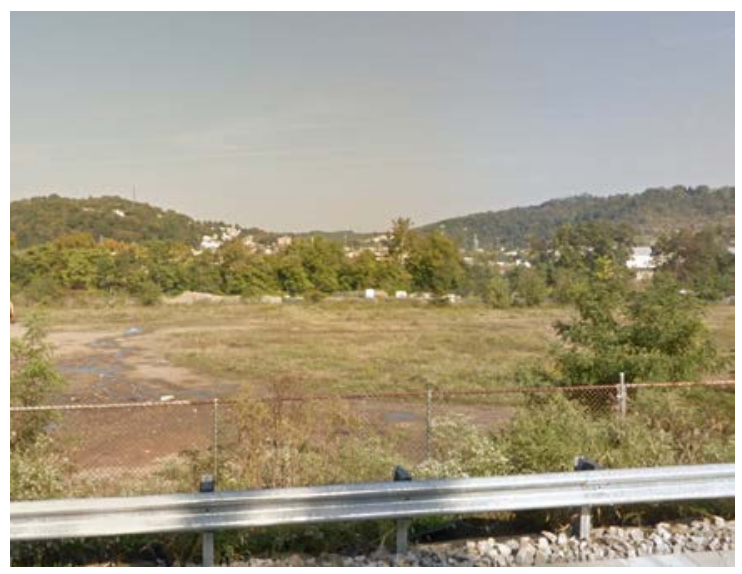

Figure 29: Vacant Pervious Land

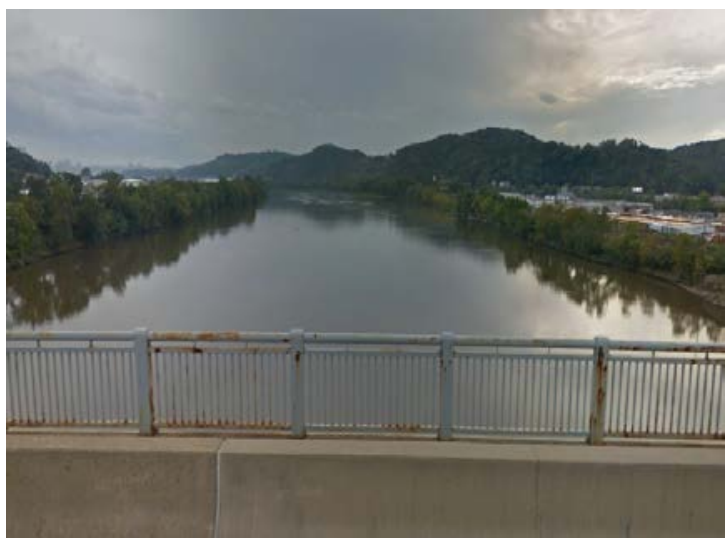

Figure 31: Allegheny River

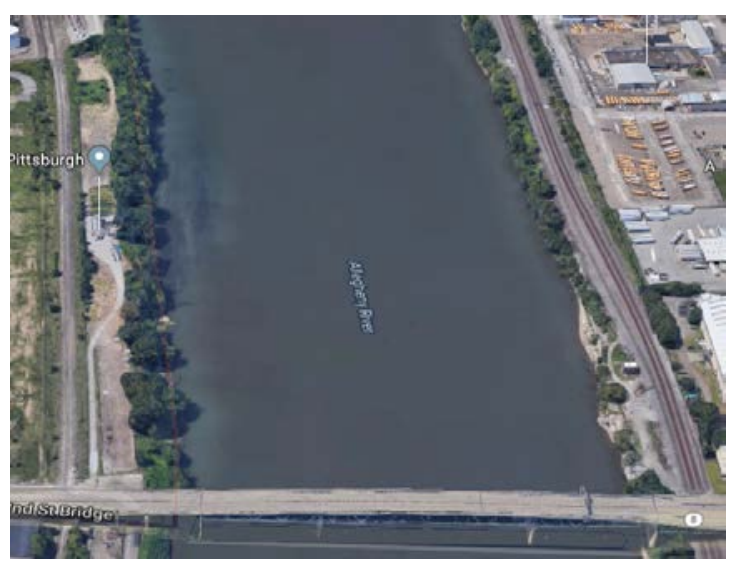

Figure 33: 62nd Bridge

\section{Google Images}




\subsection{Inventory Analysis}

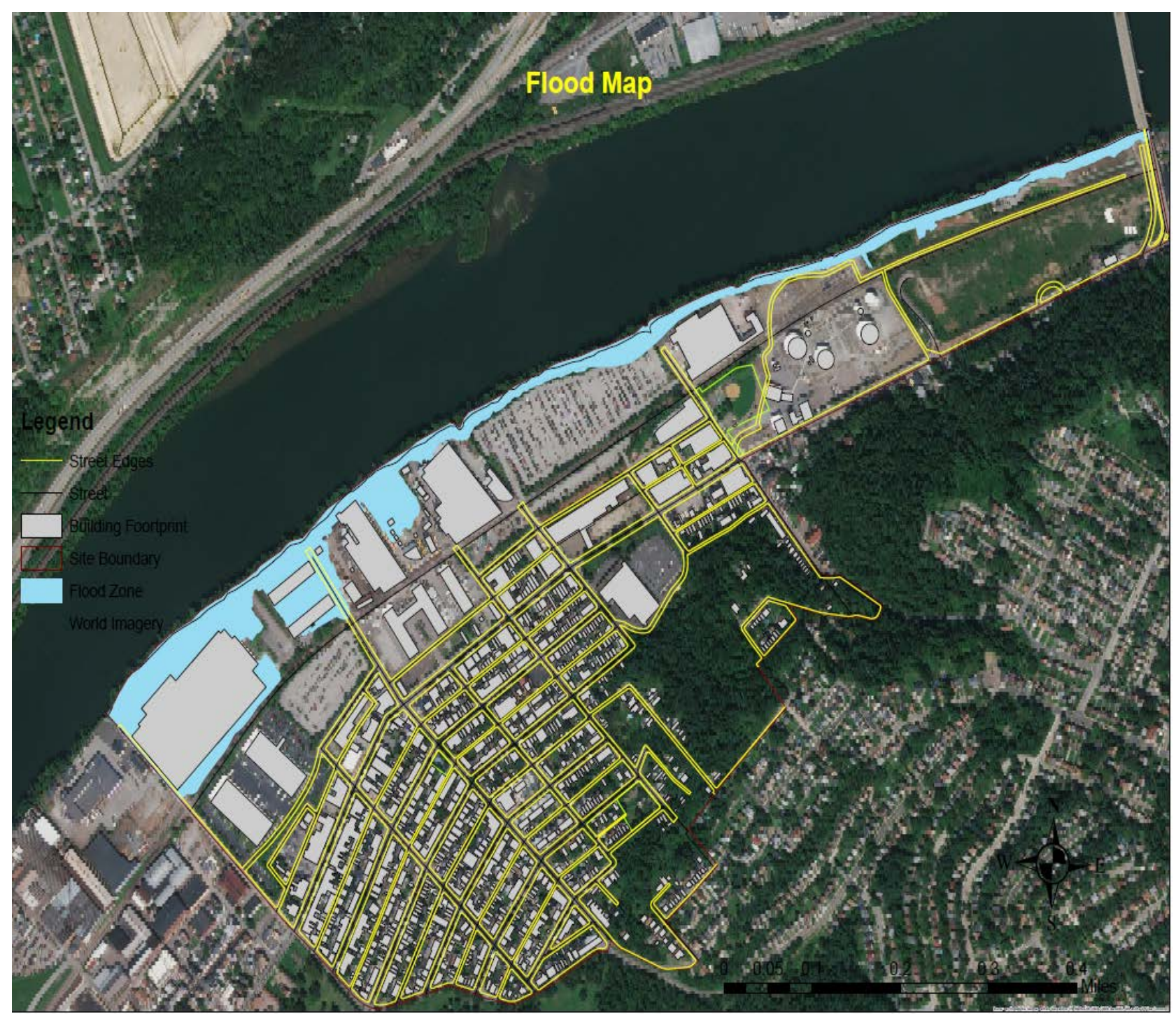

Figure 34: Flood Map of Upper Lawrenceville 


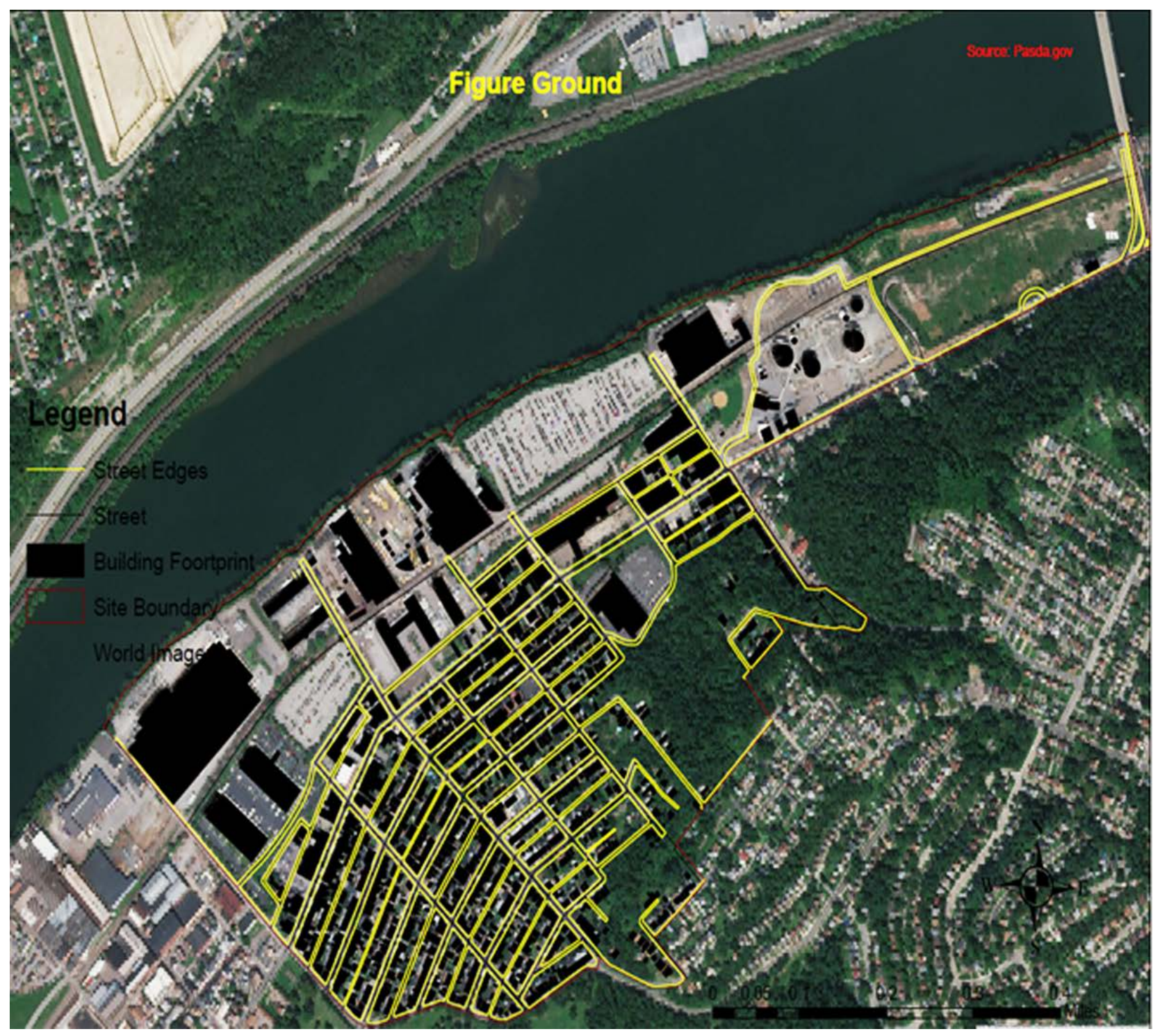

Figure 35: Figure Ground 


\section{Topography}

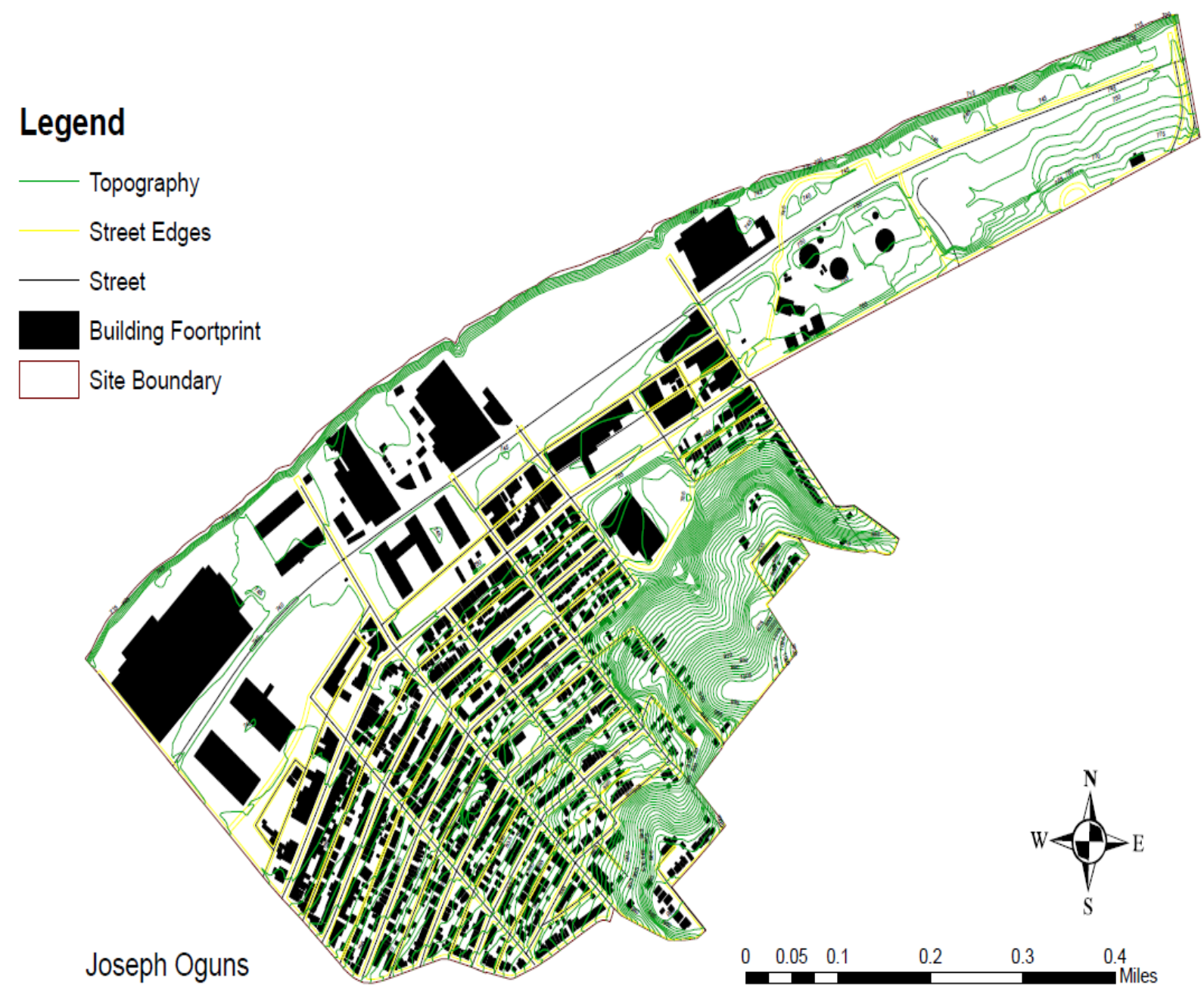

Figure 36: Topography 


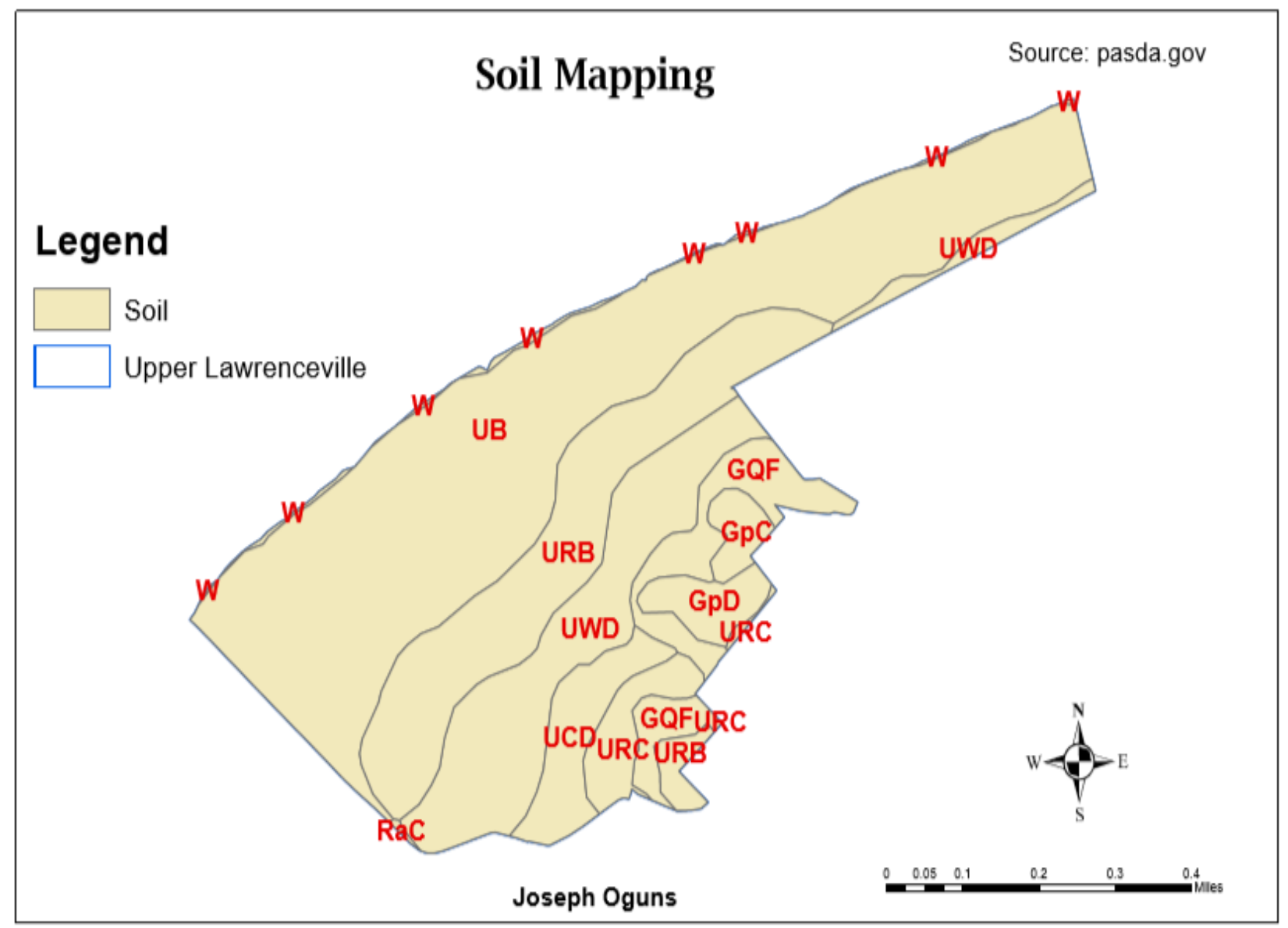

Figure 37: Soil Mapping of Upper Lawrenceville 


\section{Proposed Zoning}

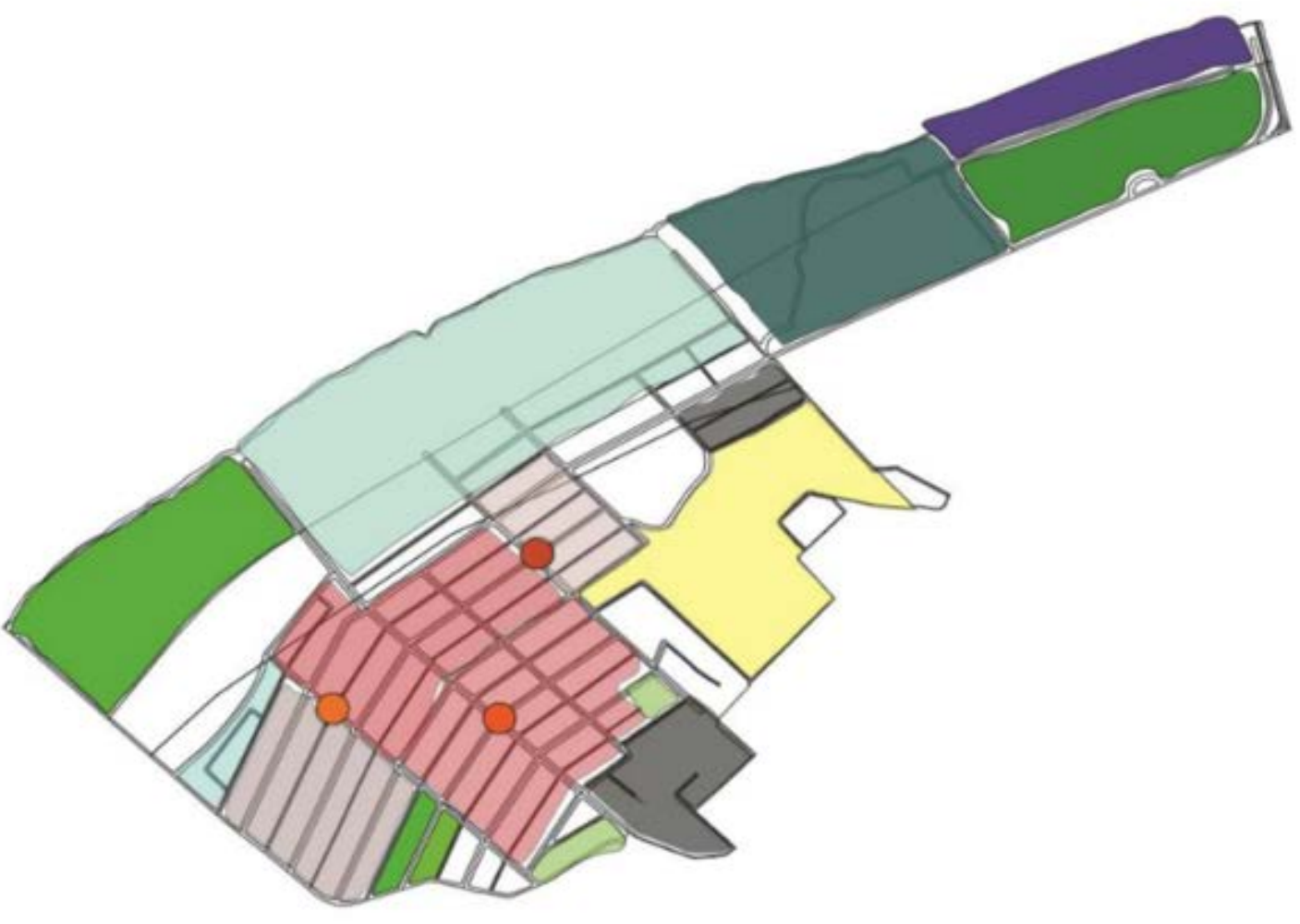

$J_{-10}^{0.51 .5}$ Kilometers

Public Park

- Riverfront

Single Unit Detached Residential High Density

Urban Industrial

Open Space

Single Unit Detached Residential Low Density

Figure 38: Proposed Zoning 
Guiding Values

Existing Parks

232928.2977 sq. $\mathrm{ft}$

Area of Existing Building

$324958.0222 \mathrm{ft}^{2}$

Overall Length of Street

$65262.9815 \mathrm{ft}$

Street Edges Length

$105181.6271 \mathrm{ft}$

Railway Length

28229.5703 ft

Upper Lawrenceville Boundary

260.349 acres 


\section{CHAPTER 5}

\section{Case Study}

\section{Smartinski Park, Playground}

\section{SCovenía}

\section{Design Year: 2015 -2016}

\section{Year of Construction: 2015 -2016}

\section{Area: 11 ha}

\section{Budget: $£ 1,000,000$}

Following to the municipal spatial planning, the park site was stated to be a green space and an infrastructural corridor, meanwhile, it is a place surrounded by sheds, garden bed, and main power lines across. As at 2007, it was used as a wedge between the city's cemetery, and the major road which caused much of reaction. In the spirit of management and new urban development, there was an announcement from the municipal and mayor's office to clear the sheds and gardening beds. It brought a concern to gardeners in the city and the future of the site. The trees were shielded, and a gardening policy was announced through the intervention of the allotment gardeners and the mayor on site. It brought about the rehabilitation of the site and reduction in the intervention. In the first season, flowering lawn mixture was planted, and the public was given access to the site as the planning and designing commence. The local stakeholders suggested the need for a park and playground. The gradual transformation of the site commences since 2007 because of its size (11 ha), and it reached its zenith in 2015. It was named Smartinski Park having a similar name with a closed road. It is seen as the biggest playground in the city. 

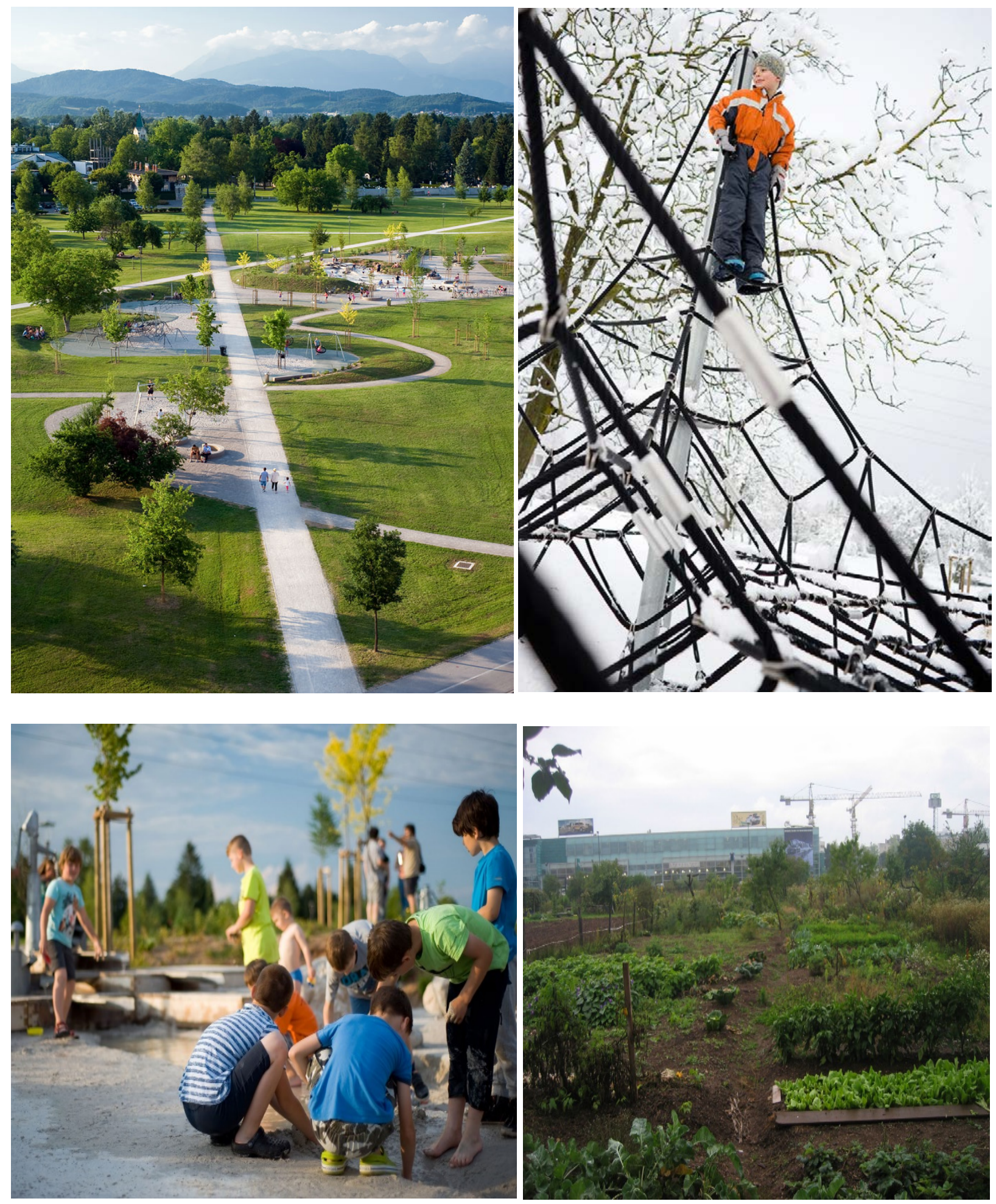

Source: Smartinski Park, Playground

There was a popular demand for a playground, at first, it sounded strange because of having a playground in the front of a cemetery. Lots prefer a playground incorporated into 
the park. The erection of walkthrough paths (2), planting big trees and the landform reshaping was the first phase of development of the park aside the existing fruit trees. It took them time to design the playground. The designers used their experience with nursery kids' involvement in play as a foundation for their design concept. The park design has water features with sand, playing landforms, vegetation, play equipment and enough space. It attracted many from far and near the city. There were lots of suggestions as people continue to use the park. The suggestions included having a scooter ride, a circular path, softly curved hills, water play pumps, tea house and soon.
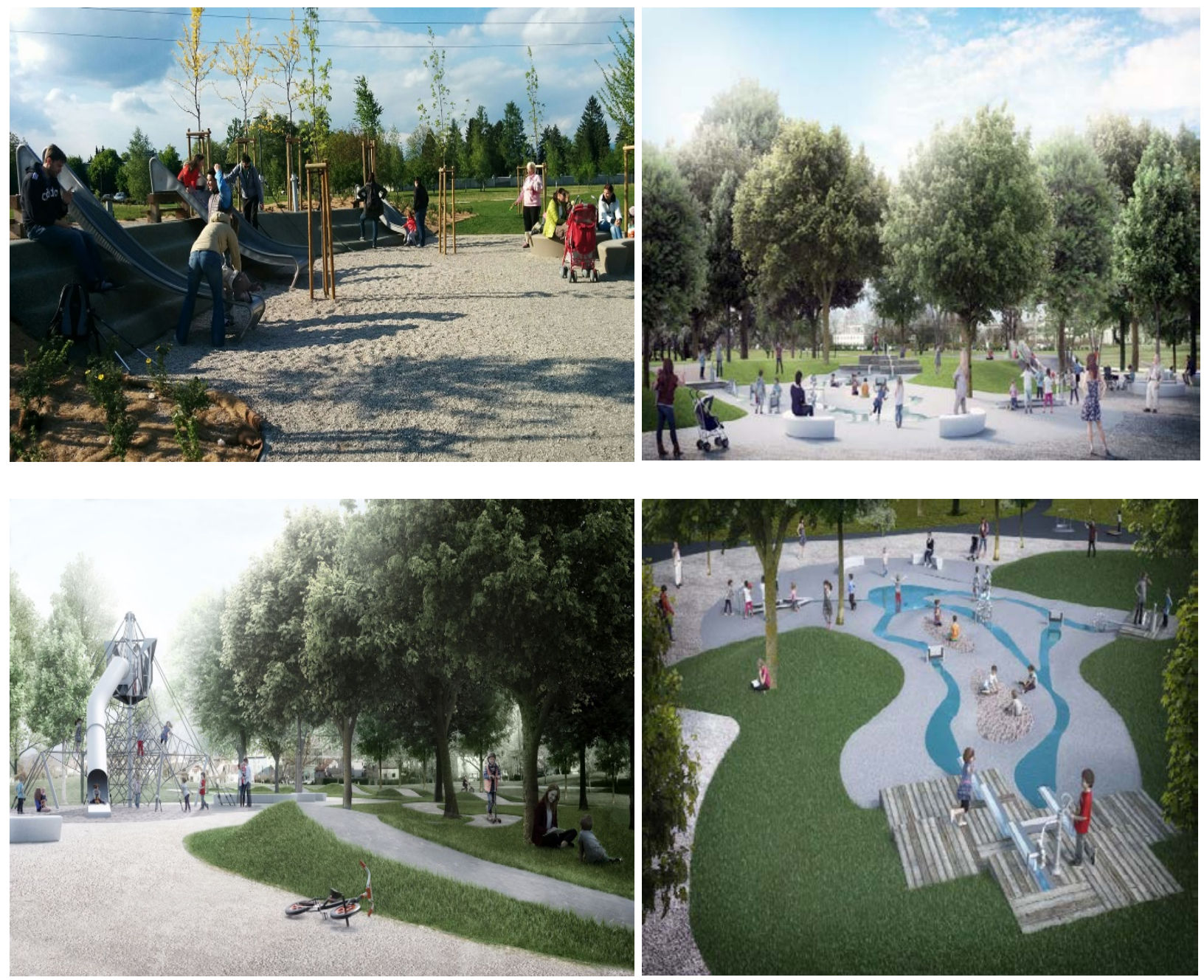

Figure 39-46: Smartinski Park, Playground, Slovenia

Source: Smartinski Park, Playground 


\section{Tom Hanafan River's Edge Park, Phase 1}

\section{Iowa}

\section{Budget: \$11.5 million}

Size: 85 acres

\section{Project type: Waterfront redevelopment}

\section{Completion Date: 2013}

The project Tom Hanafan River's edge park is in Council Bluffs, lowa. It is a floodplain area along the Missouri River lacking public access. The great flood in Missouri River 2011 has affected the area; the ecological value of the woodland reduced because of the invasive plants. Invasive plants removal and reforestation of the Ton Hanafan River Edge were the strategies used to revive the ecology and operations of the site. To mitigate the floodplain challenges, bioswales and meadow planting were used to increase the floodplain storage capacity. A 2,000-seater amphitheater was designed on top of an existing levee bordering a 20 acre of native meadow.
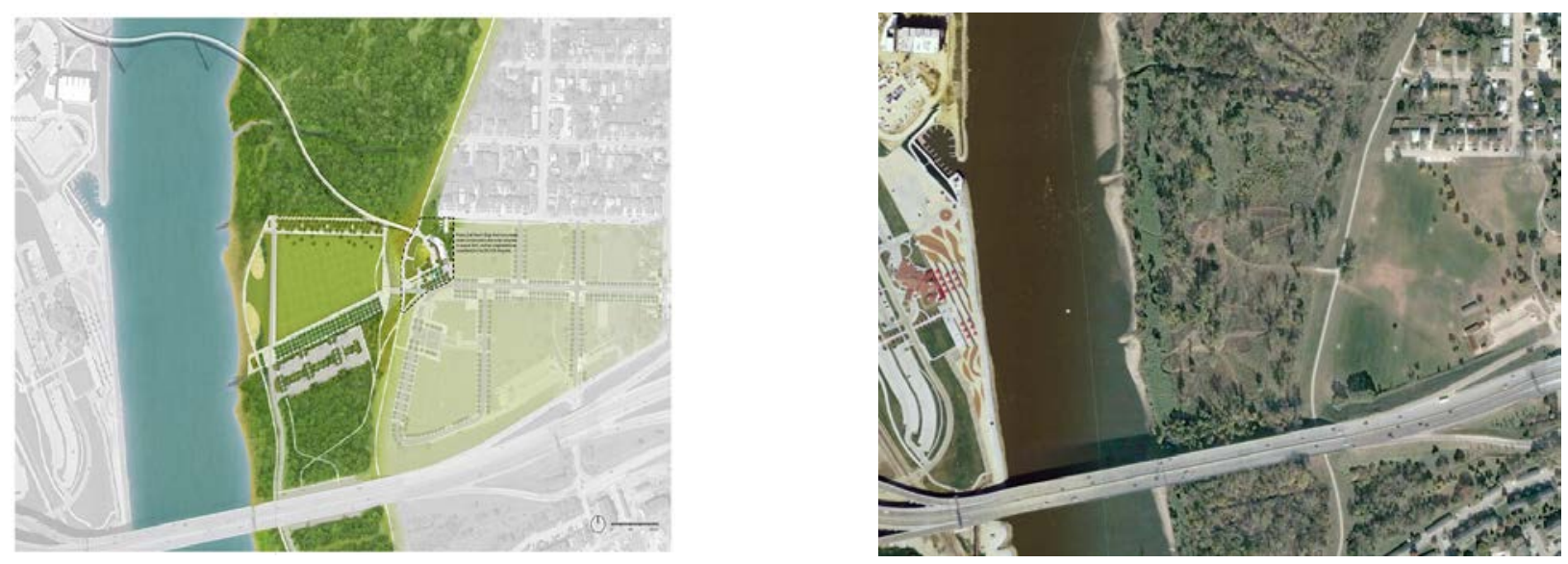

There was a cost comparism and it was discovered that there is going to be savings on maintenance to installing the meadow, and it will help the park to save $\$ 4,700$ annually. The cost of maintaining a meadow is however 3.85 times lesser to the traditional mown lawn. 

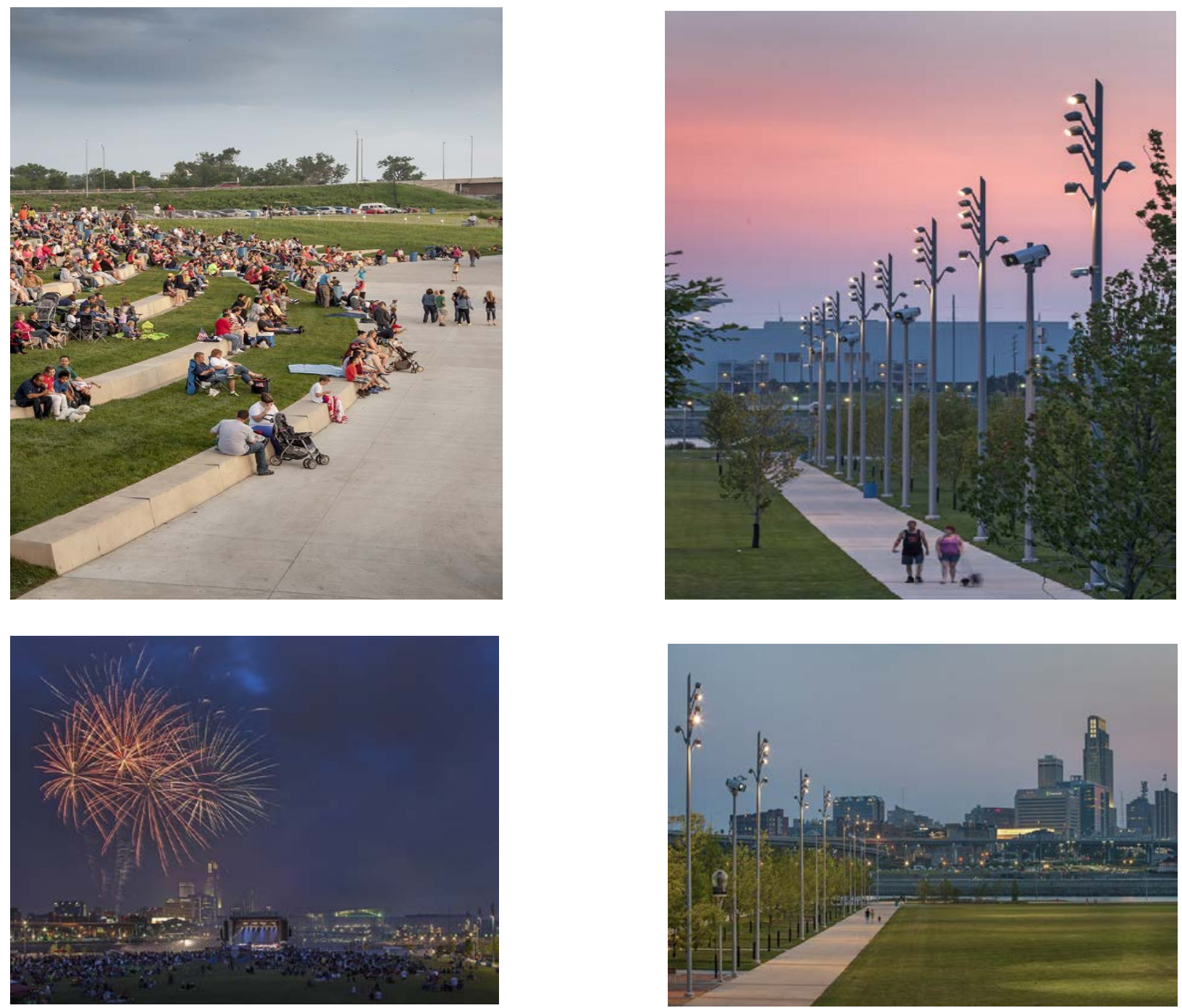

Figure 47-52: Tom Hanafan River's Edge Park, Phase 1, lowa

Source: Tom Hanafan River's Edge Park, Phase 1

The sustainable features of the project include the 4 acres great lawn that improves filtration process during flooding and rain, the outdoor amphitheater that accommodate 2,000 users, flood tolerant species (biofiltration plants), 3 infiltration (biofiltration) basins in the parking lots to mitigate lot runoff and checkmate stormwater, walk along the riverfront (Missouri River), regional trail system through the eastern landing, native plant materials. 


\section{Garden of Seven Moments}

\section{Switzerland}

\section{Design Year: 2013}

\section{Year built: 2014 -2015}

The garden was divided into seven interconnected moments, it is featured by sun and wind exposure, terrain conditions and the complexity of vegetation. The moments are divided linked to the landscape surrounding via trails or views. The sloping shade garden of the house surroundings defines the links of the entrance floor to the terraced areas. There is a secret bamboo canal; the second moments that confuse transient to lead them to a paly of light. The sound of water from the rock fountain at the end leafy axis. The border of the shrub and the Mediterranean perennial connects to a long black wall on property edge and the bottom through a grassy ramp as the third moment. The fourth moment is the seasonal changes where the little maintained flowering perennials and a mixed edge of herbaceous are celebrated. The growing of fruit trees on a meadow terrain (terraced slope) which is formerly part of the extended vineyard is dedicated to the fifth moment. The sixth moment is centered on giving her users pleasure. It is located around a pergola sown with wisteria and perfumed Jasmine near the swimming pools. The last moment is centered on a reflection of specific views to give room for meditation along the way.

The project helped to bring in new intervention to the garden which brought a change in perspective of the entire landscape and the inhabitation. Native and non-native plants (grass and shrubs) were used to design on the sloppy topography which gave the garden a unique description of 'combining topography and vegetation'. 

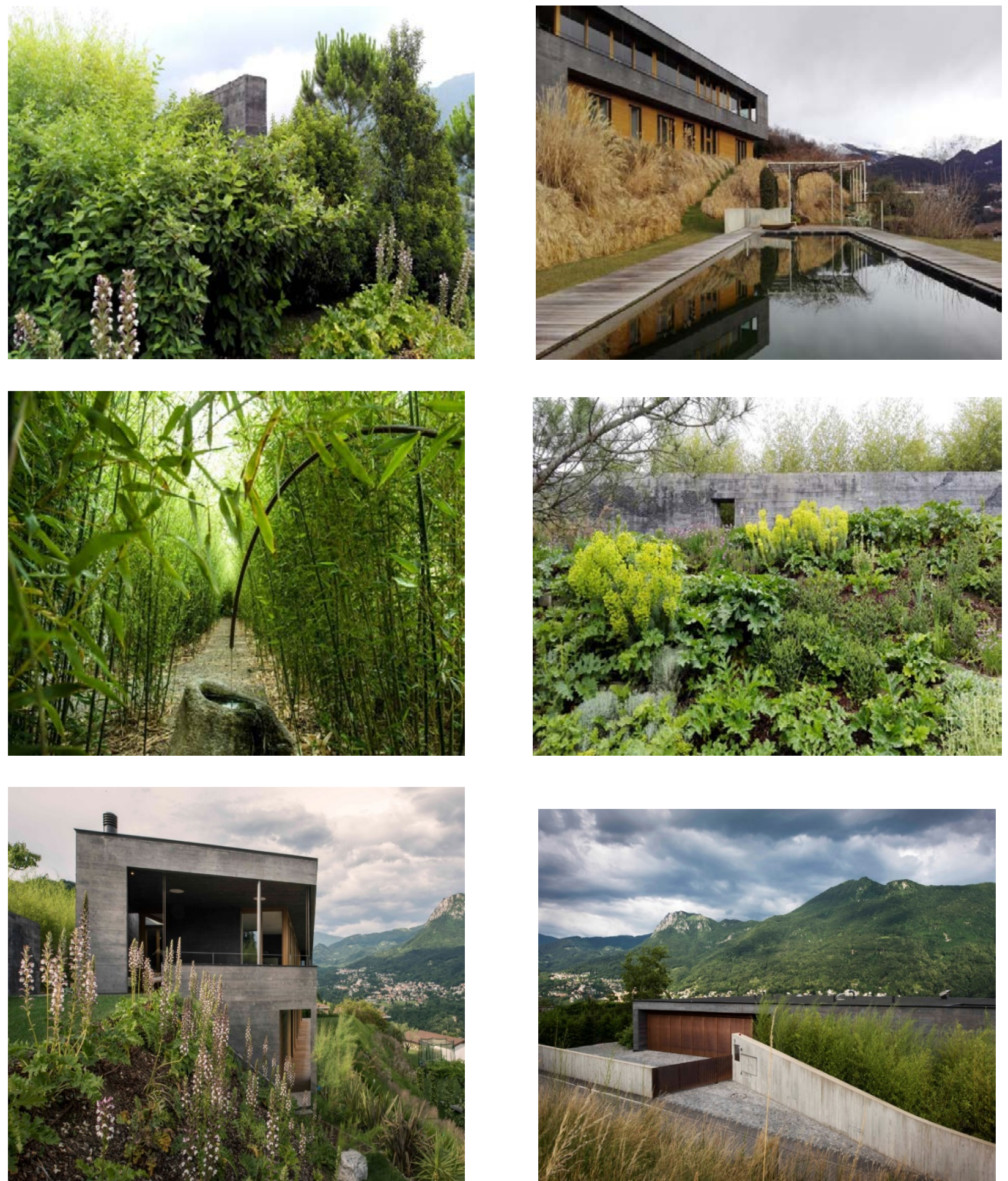

Figure 53-58: Garden of Seven Moments, Switzerland

Source: Garden of Seven Moments 


\section{Drapers Fíeld}

\section{London}

\section{Commissioned: 2010}

\section{Construction Completed: June 2014}

\section{Budget: $€ 4.3 \mathrm{~m}$ for 3 sites}

Drapers field the first Olympic park in east London. The park was contracted to Kinnear Landscape Architecture (KLA) from the available fund (Olympic section 106 funds) by the borough of Waltham Forest. Drapers Park, location is a connection to the communities in east London through the KLA designed Temple Mill Lane, the new East village projects and the Olympic park. Draper's field was mainly a football arena not used efficiently by the people of the community. A client before KLA proposed interventions on the play area, pavilion, and the sports facilities. The idea brought about having a bigger Olympic park that will accommodate children, youth for the current and new communities into sports and other informal activities. The park will also encourage sports and play along the route to Chobham Academy near the Olympic village. KLA designed the school exterior and the landscape with creative interventions and provided good sports facilities. The creative design of the landscape enhances cycling and cycling training and other forms of play. Other elements that make the place the Olympic park an attractive and enjoyable place are the corrugated forms made up of concrete and grass; water play implanted into the corrugated forms that produce splash ponds for children to control the water's flow; obstacle bike track along the school route; the enhanced pavilion for community café and hub. 

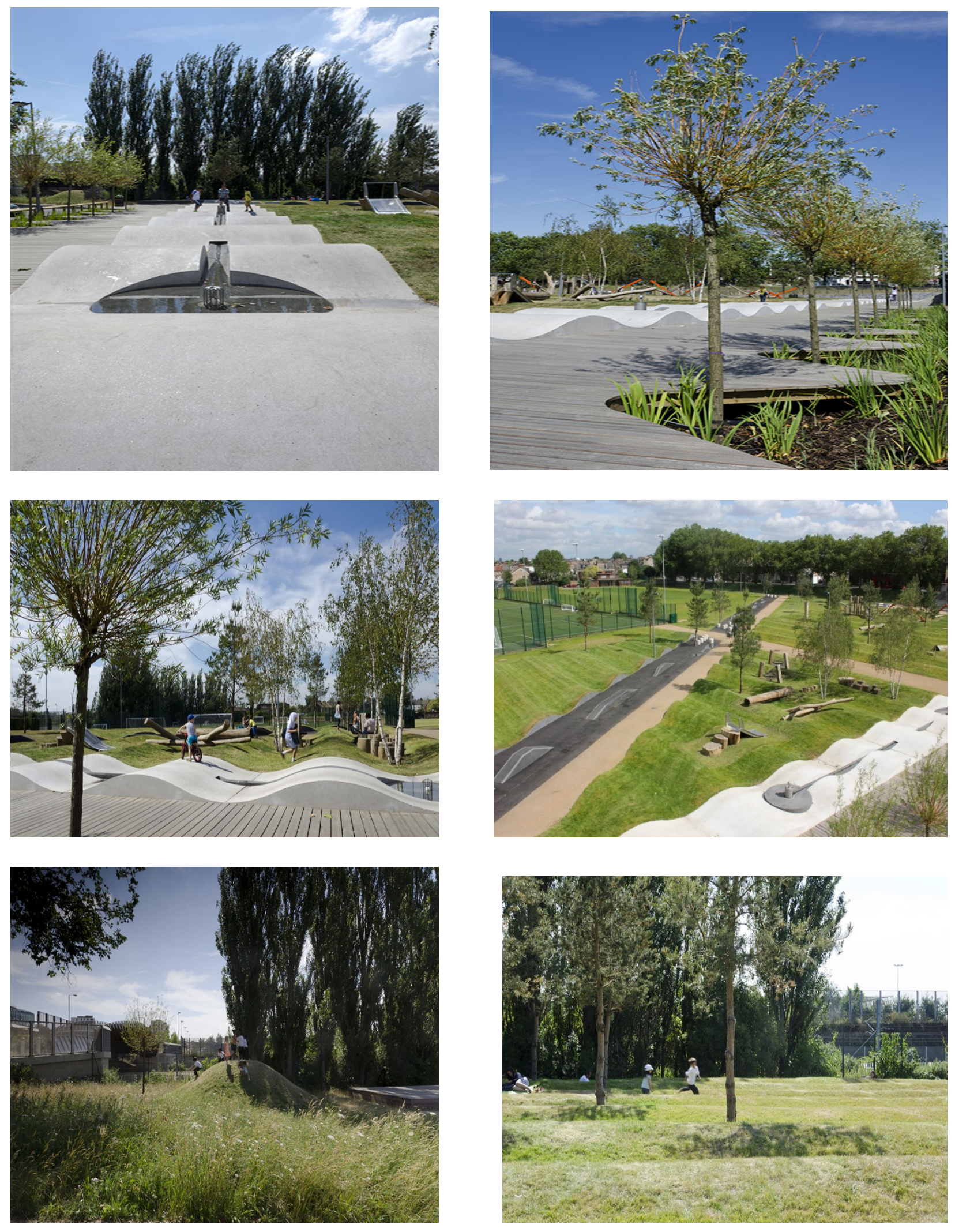

Figure 59 - 64: Draper's Field, London

Source: Drapers field 


\section{CHAPTER 6}

\section{Design}

\section{Designing a User Friendly Upper Lawrenceville}

As established in the preliminary chapters of this thesis project. The movement of people is increasing across the world, which is bringing imbalance by cities and rural areas. However, the ecosystem is passing through stress in areas like housing, living density, flooding, air pollution and lots more. The fact remains that people living in cities need to be in contact with the rural life to maintain their root. At present it is becoming a challenge for people living to have a touch of their rural life.

This design proposal is centered on creating a health friendly upper Lawrenceville, to also be an attraction to other neighborhoods and visitors from other regions. Through sustainable interventions that will foster development, economy, connections; pedestrian circulations, and water connection from upper Lawrenceville to Etna, Public green and blue infrastructure, creating a community and lots more. A prototype of the design concept can also be reproduced in areas that plantations are prioritized from the i-Tree Landscape model used in this study.

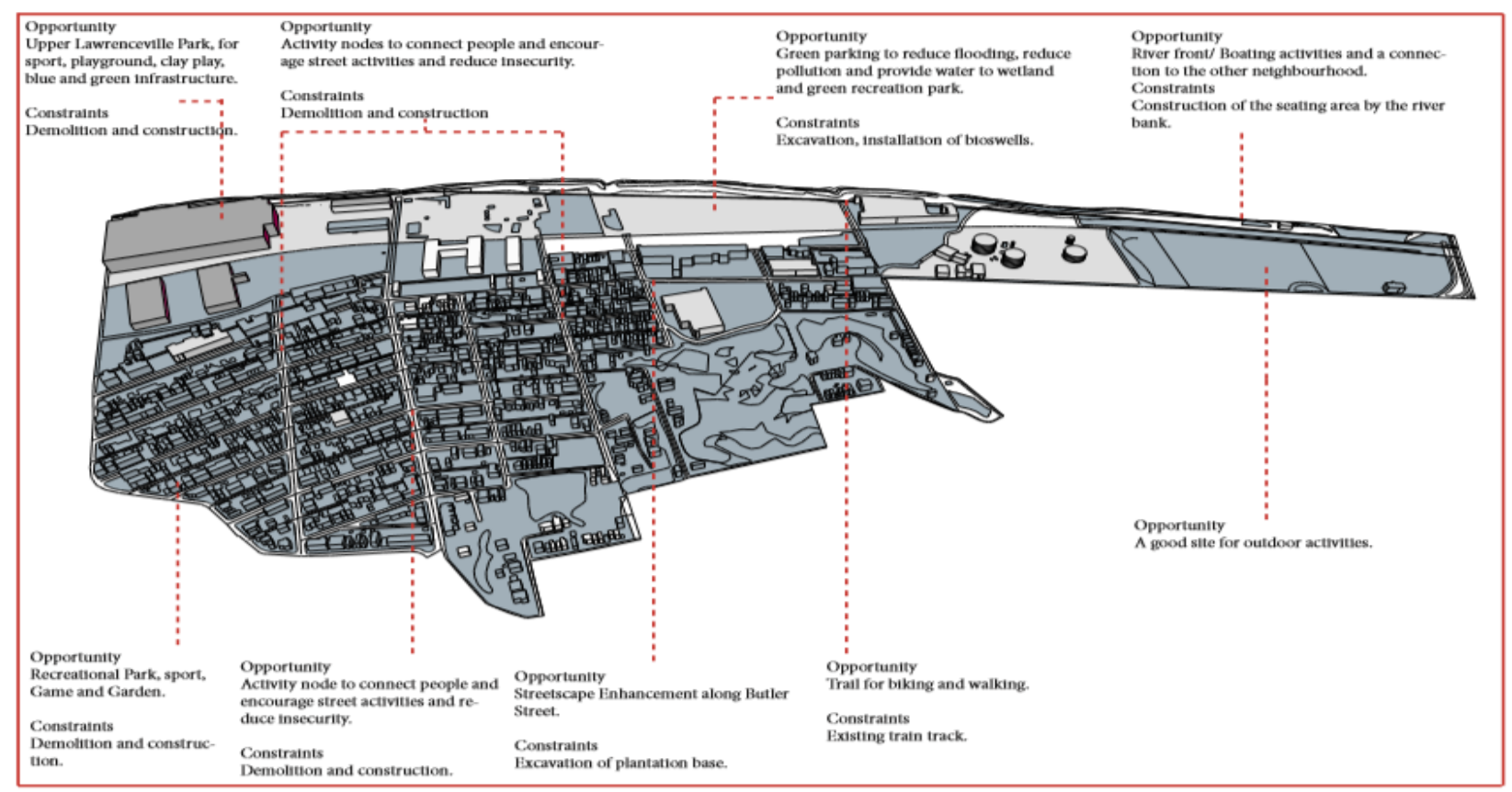

Figure 65: Composite Analysis Map 


\title{
Opportunities
}

\author{
Streetscape
}

Activity Nodes

Parks

Green Parking

Waterfront

\section{Constraints}

\section{Zoning and regulations}

Flood zones

Railroad

Construction along the riverfront 


\section{Master Plan of the Site}

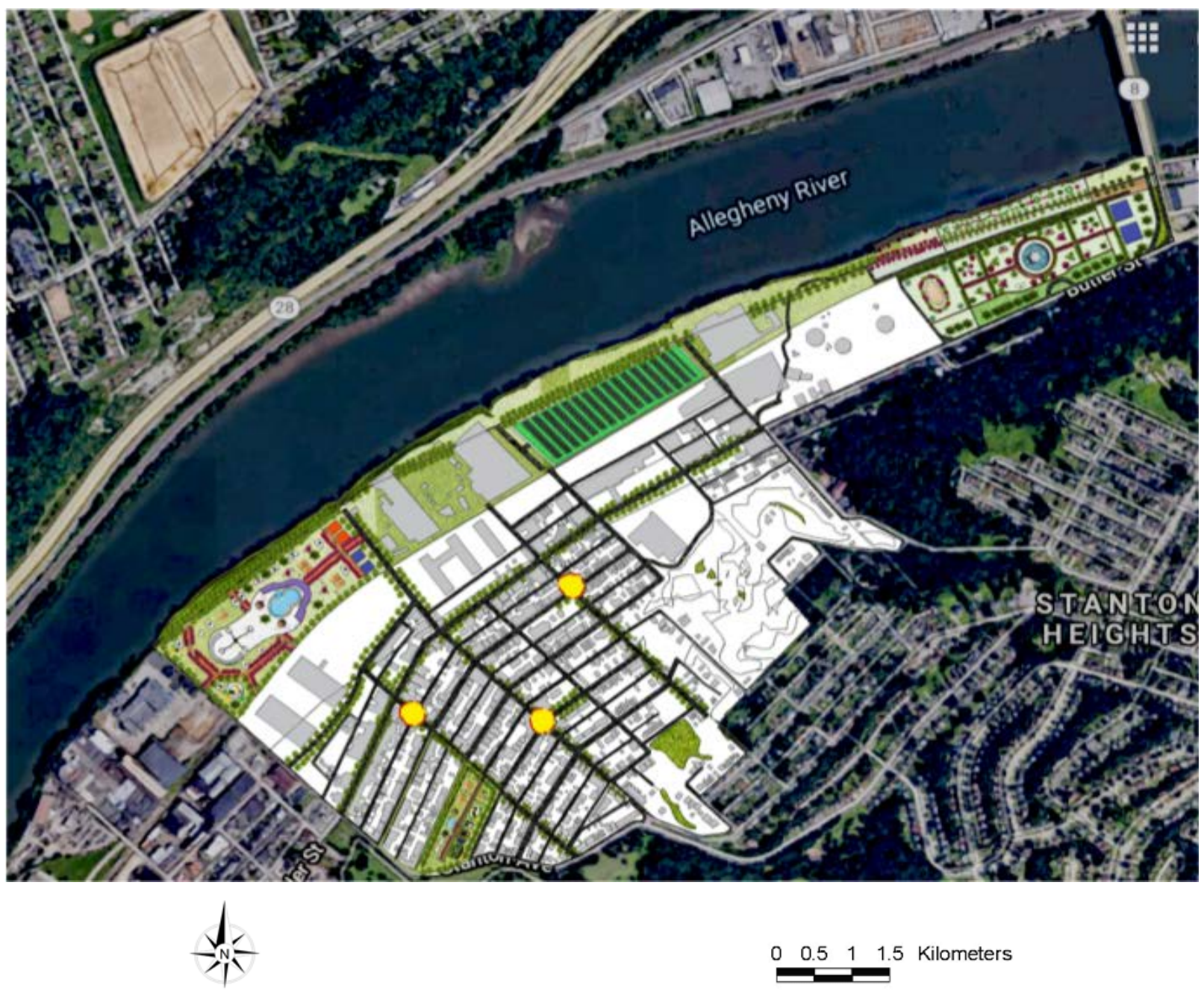

Figure 66: Master plan of the site 


\section{Masterplan Description}

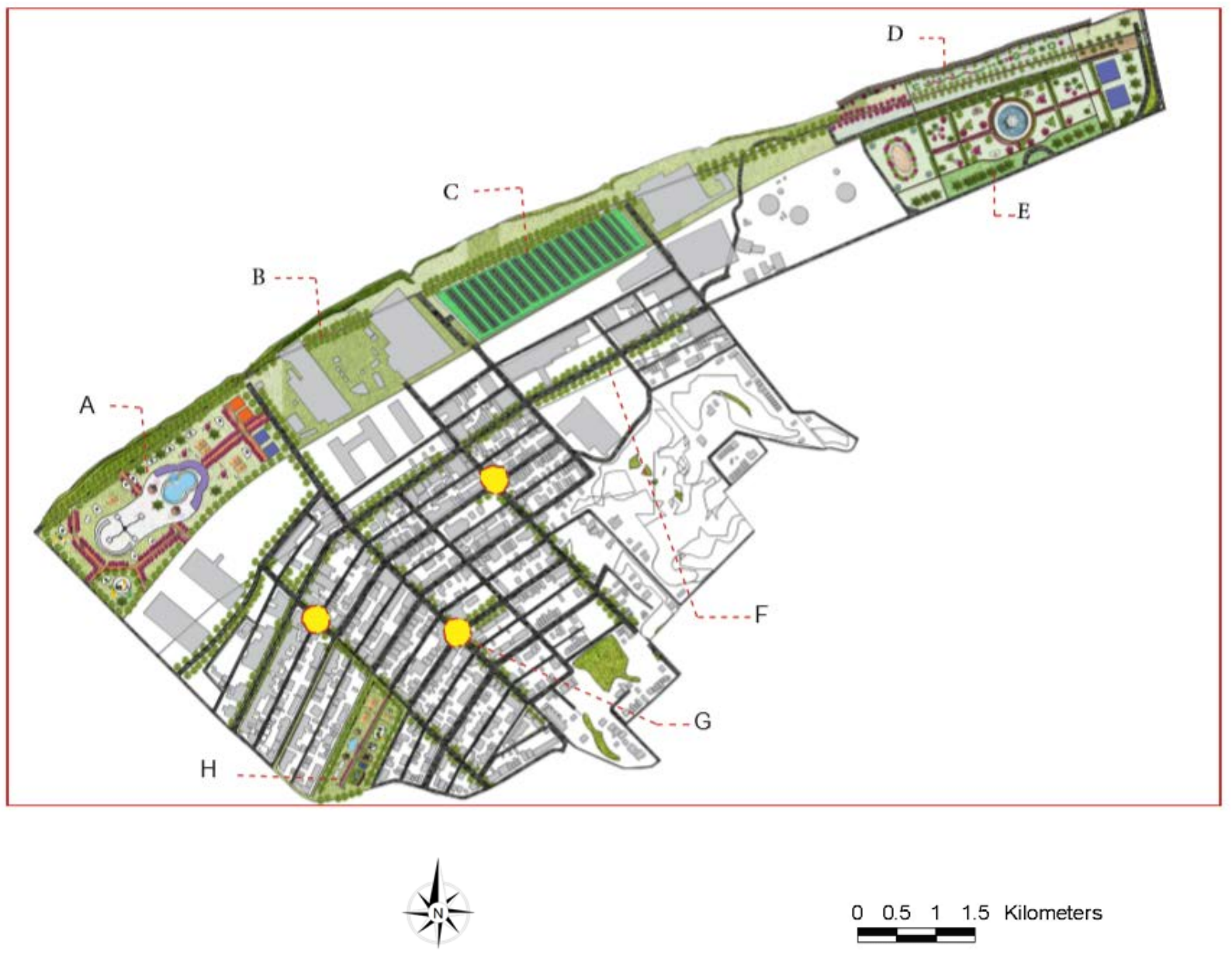

Figure 67: Masterplan Description of the site
A - Upper Lawrenceville Park B - Trail C - Green Parking
D - Riverfront/Garden E - Outdoor Events Center. F - Green Streets
G - Activity Nodes H- Recreational Park/ Meditation Garden 


\section{Program Description}

\section{Public Green should be distributed at 1500-foot interval}

"The human body does not wear out with use. On the contrary, it wears out when it is not used" (Alexander C. et al., 1977)

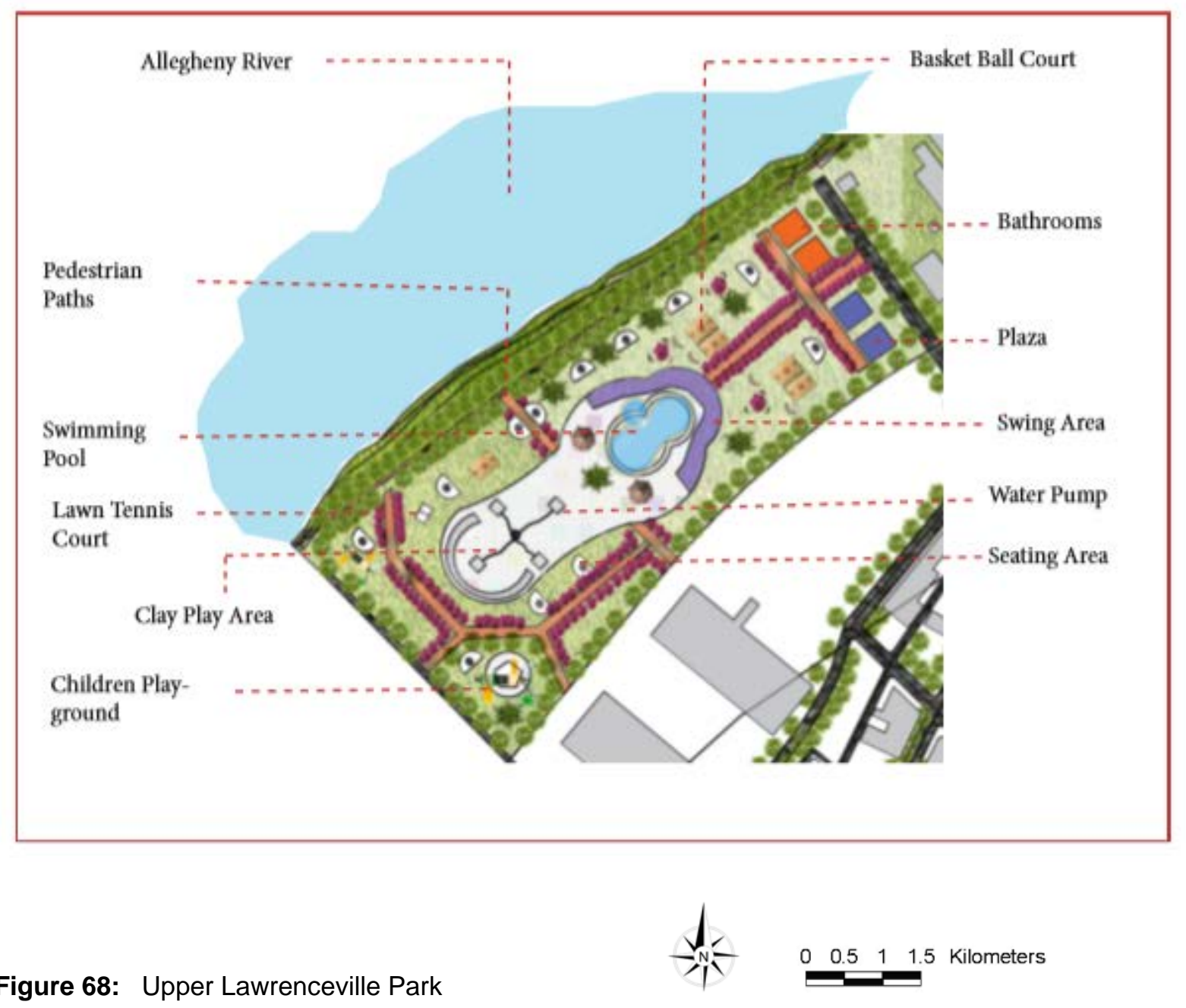


Today, water is pushed down not seen by people to sit besides, swim in, or use their legs to flag. What we see is pave all-around cities. I am advocating that water should be an element in building or parks in a city. Children are enthralled by water in motion, you can see them play around it forever. There should be places in the community where people can effectively use both their body and mind to work by using the blue green infrastructures in the environment and the working environment. Part of the solution to this is to encourage physical activities close to houses and places of work. There should pool (for swimming) and still water (example pond, lake...) in every neighborhood. The pool should be designed where the main entrance be shallow with a depth of 1 to 2 inches and expands gradually. The proposed Upper Lawrenceville Park is centered towards promoting these objectives. It has a clay play area for children to play by molding with their hands with the water coming from the four-water pumps, playground, swings, swimming pool, seating areas, lawn tennis, basket ball court and plaza. 


\section{There should be reduction of pave most especially in flood plain areas}

"There is too much hot hard asphalt in the world. $\mathcal{A}$ local road, it only gives access to buildings, needs a few stones for the wheels of the cars; nothing more. Most of it can still be green" (Alexander C. et al., 1977)

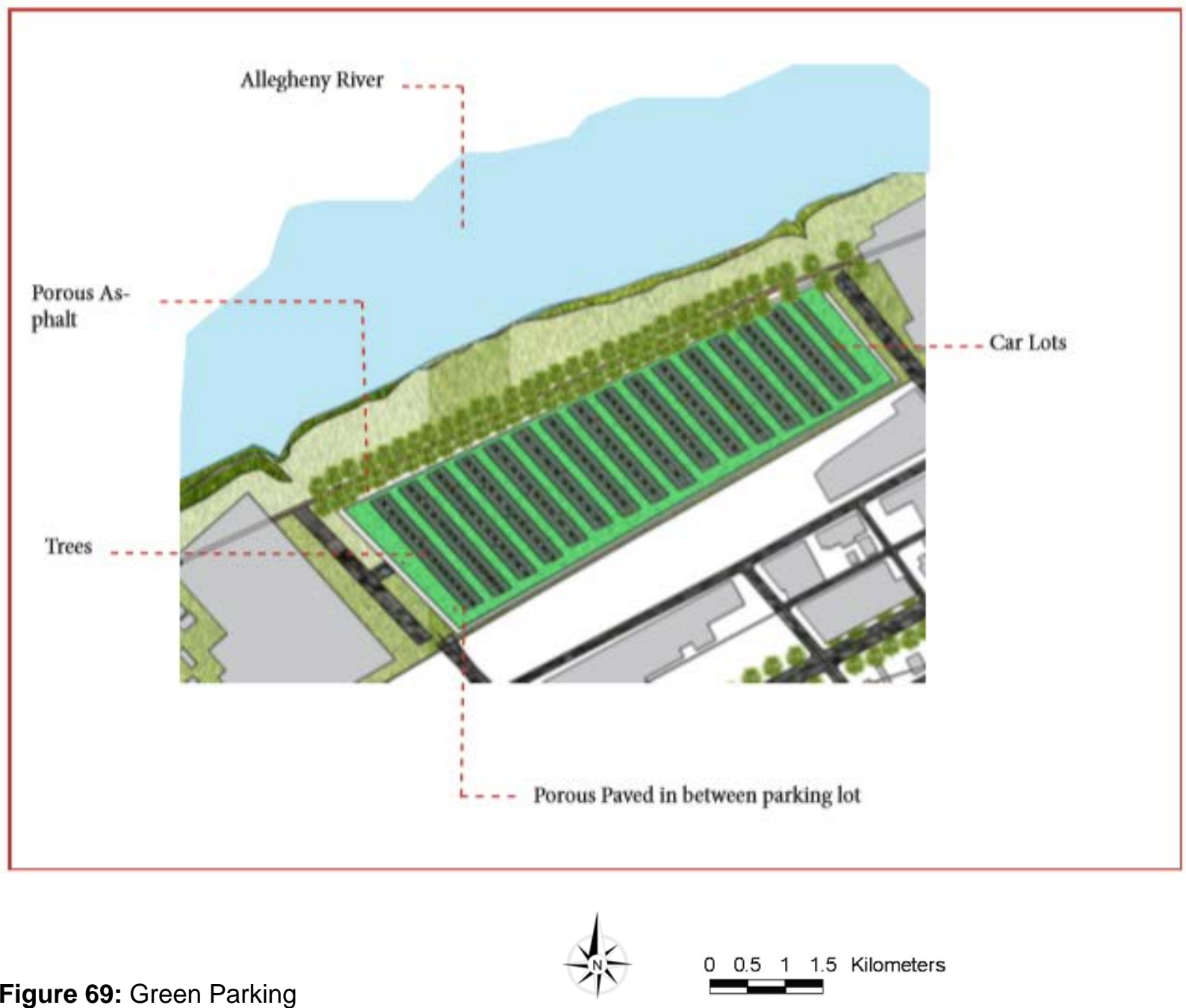

Green parking is proposed in this region to reduce flooding and as a means of incorporating green infrastructure to the location that is mainly used as the children hospital shuttle lots. The runoff from the parking lots can be channeled to wetlands, and 
green recreational sites that are close. It further improves the quality of the water through filtration of pollutants. It has the potential of reducing runoff from 50 to 80 percent.

\section{Buildings should not be used as focal point in outdoor spaces}

\section{"People use open space if it is sunny, and do not use it if otherwise, in all but desert climates" (Alexander $C$. et al.,}

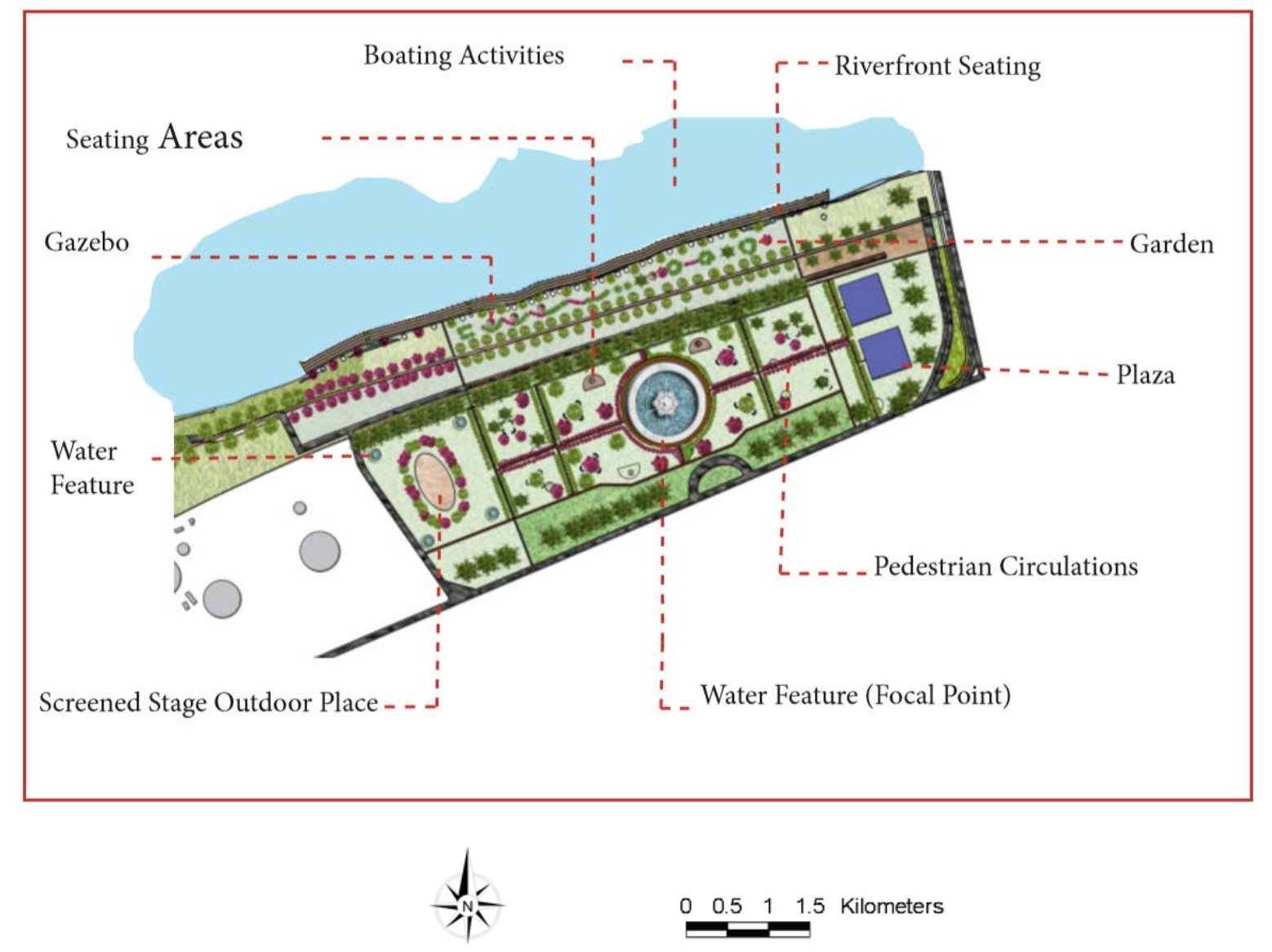

Figure 70: Outdoor Activities Center

There should be a form of enclosure in an outdoor space and it should be in areas that have good access to sunlight. People tend to use the sunny side of the outdoor space. However, there need to be a balance between the sun and shade. People need the trees in the outdoor space to sit and rest on. The proposed outdoor space is located near the riverfront which will give the people a good view of the activities that take place by the riverfront, the water feature on the middle serves as the focal point of the outdoor space 
with walk areas for people to move and interact and seating areas and plaza to buy things. The lawn spaces are free for other forms of outdoor games by the users. The proposed program at the riverfront will provide boating activities, fishing, seating, and garden to the neighborhood and provide a link of connection to the Etna neighborhood.

\section{Every Community and Neighborhood should have a place for individual and} collective sport, and located in place that will attract tourists. "If children are not allowed to utilize the whole of the adult world around them they cannot become adults. The Modern society are so dangerous that children cannot be allowed to utilize them freely" (Alexander C. etal., 1977)

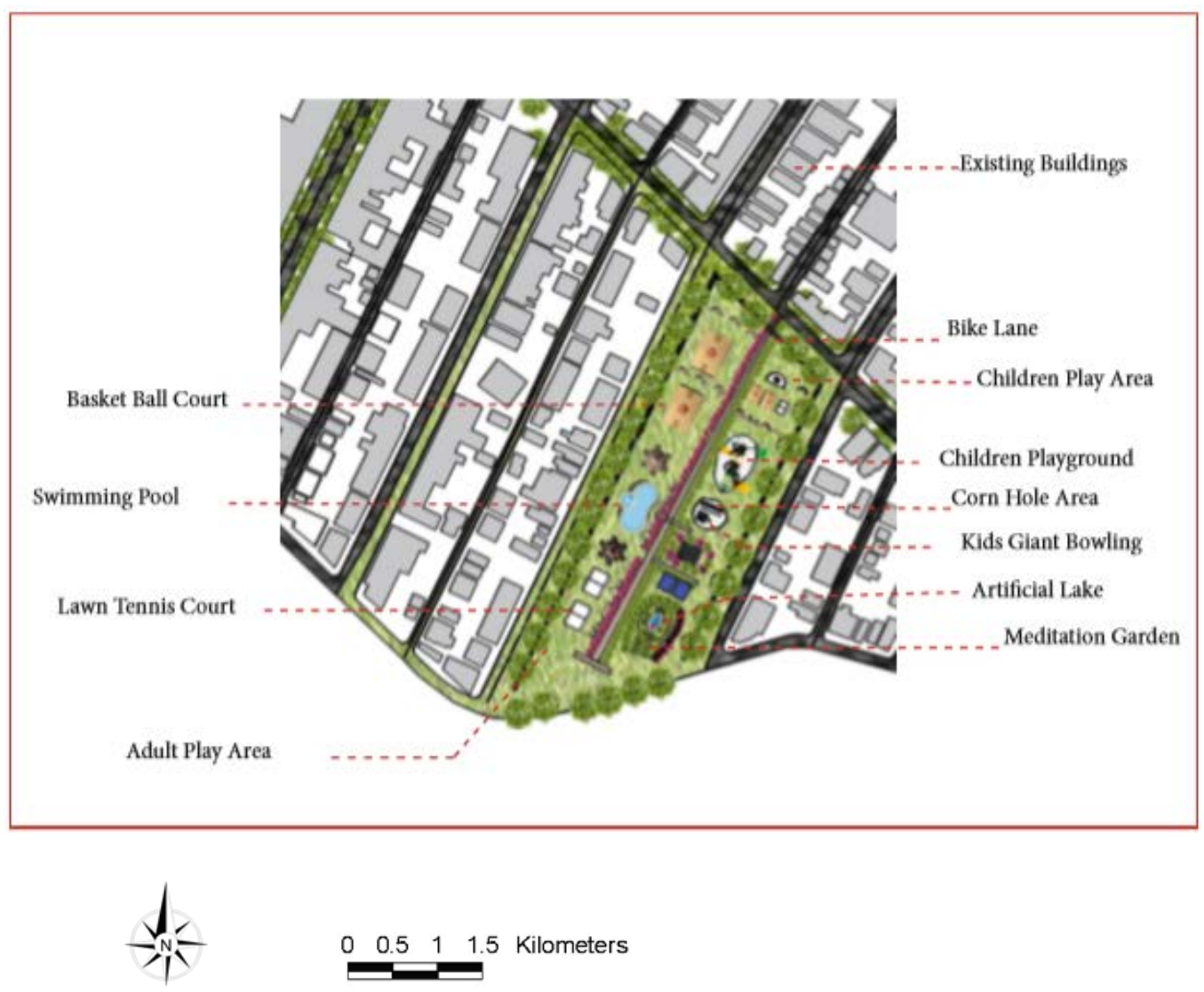

Figure 71: Recreational Park 
Doing and copying are two platform's children used to learn. They need a space to make it a reality, but as it is, children are not safe to play around cities because of the fear of being hit by cars or trucks. The recreational park proposed will give them the environment to have a safe and enjoyable experience. Biking is another activity that is good for the environment and not expensive to acquire, however the design of the environment does not make it to work. Bike paths should be designated with a unique color or symbol to create awareness to the road or park users, especially where bike paths are shared by pedestrians. The recreational park proposed in the above figure has a designated place for biking activities.

There should always be a place free from noise and protected from buildings that is in walkable distance in busy areas of the city, where people can use during lunch time and other free times to meditate and feel the beauty of nature. A garden is designed in the proposed recreational park where visitors will have a feel of nature.

The graph below gives an understanding of the benefits one can get from engaging in exercises.

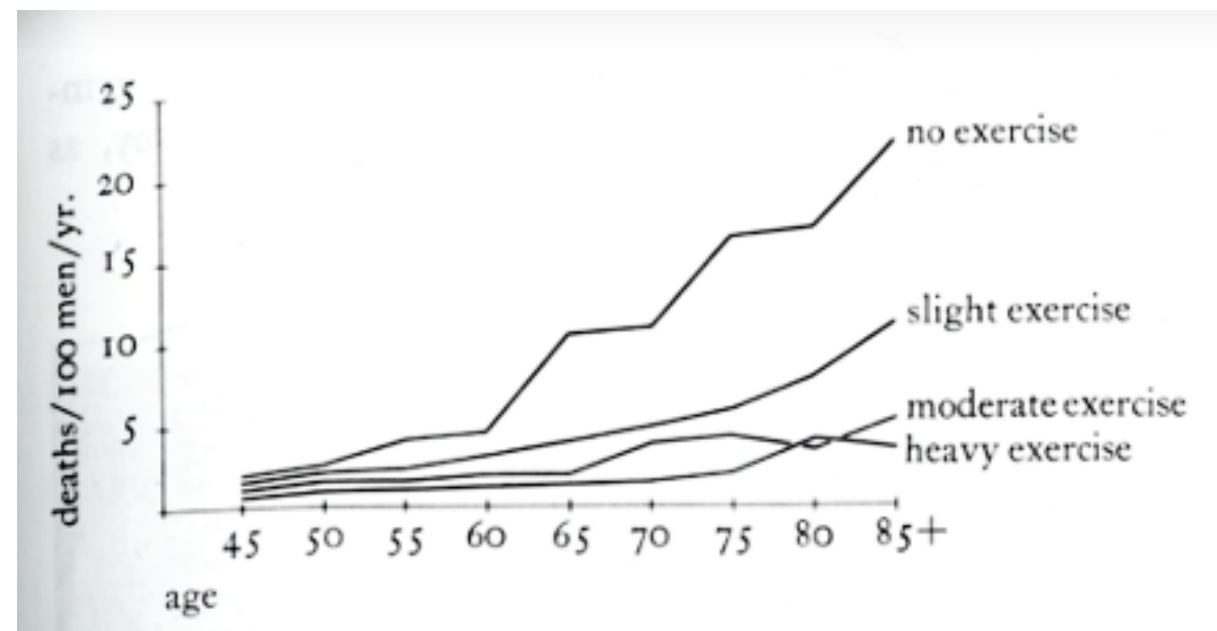

You will probably live longer if you exercise regularly. (Graph adapted from E. G. Hammond, "Some Preliminary Findings on Physical Complaints from a Prospective Study of $1,064,004$ Men and Women," American Journal of Public Health, $54: 11,1964)$.

Figure 72: Exercise and Death Rate Graph 


\section{Activity Nodes should be distributed in the Neighborhood at walkable}

\section{Interval}

Subcultures need to have a center for its public life, a place where people can go to see people and to be seen" (Alexander C. et al., 1977)

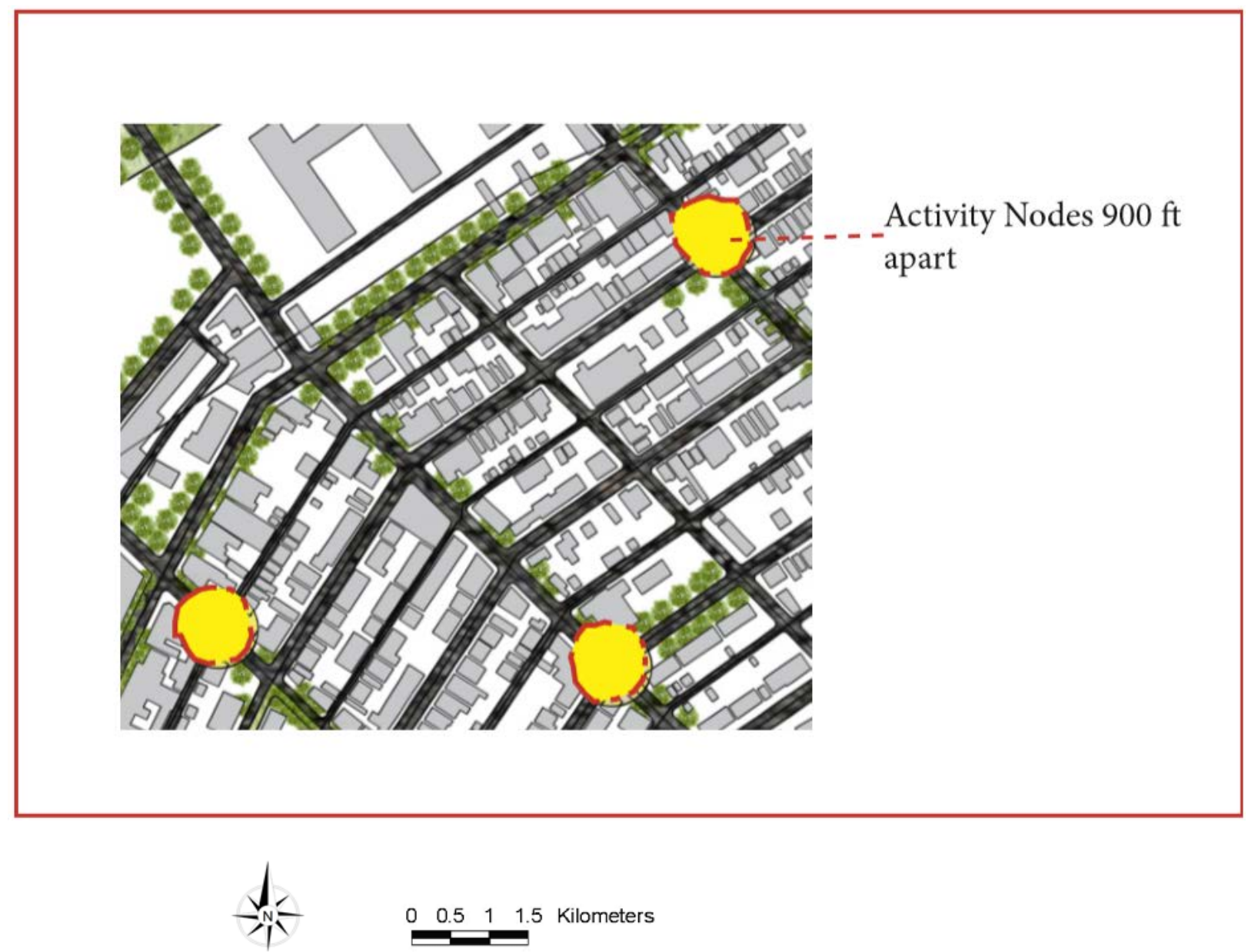

Figure 73: The 3 Activity Nodes

One can identify hot spots areas and use it as a bearing for designing other activity nodes through the paths to create a network. The activity nodes should be a place to connect people like having a public square that will promote night activities like street theaters. People tend to use places that are not too far from them. The activity nodes should be like 10 minutes walk from each other and the paths leading to those nodes should be full 
of activities like carnivals, shopping arena, ice cream shops, coffee shops, churches, and movie centers. The path networks should be properly lighted to encourage high pedestrian density in the day and night. It is believed that busy pedestrian paths most especially in the night tend to reduce the rate of crime. Activity nodes will reduce the use of cars most especially when taking short trips and bike racks should be positioned there. Residents will be encouraged to use their bikes, foot to move within their neighborhood as a lifestyle, it will also further reduce the problem (noise, ill health, air pollution, eyesore) brought by the use of cars.

\section{There should be layout of foot Paths, Bike Paths and Green Street in the neighborhood}

"The simple social intercourse created when people rub their shoulders in public is one of the most essential kind of social glue in society" (Alexander C. et al., 1977)

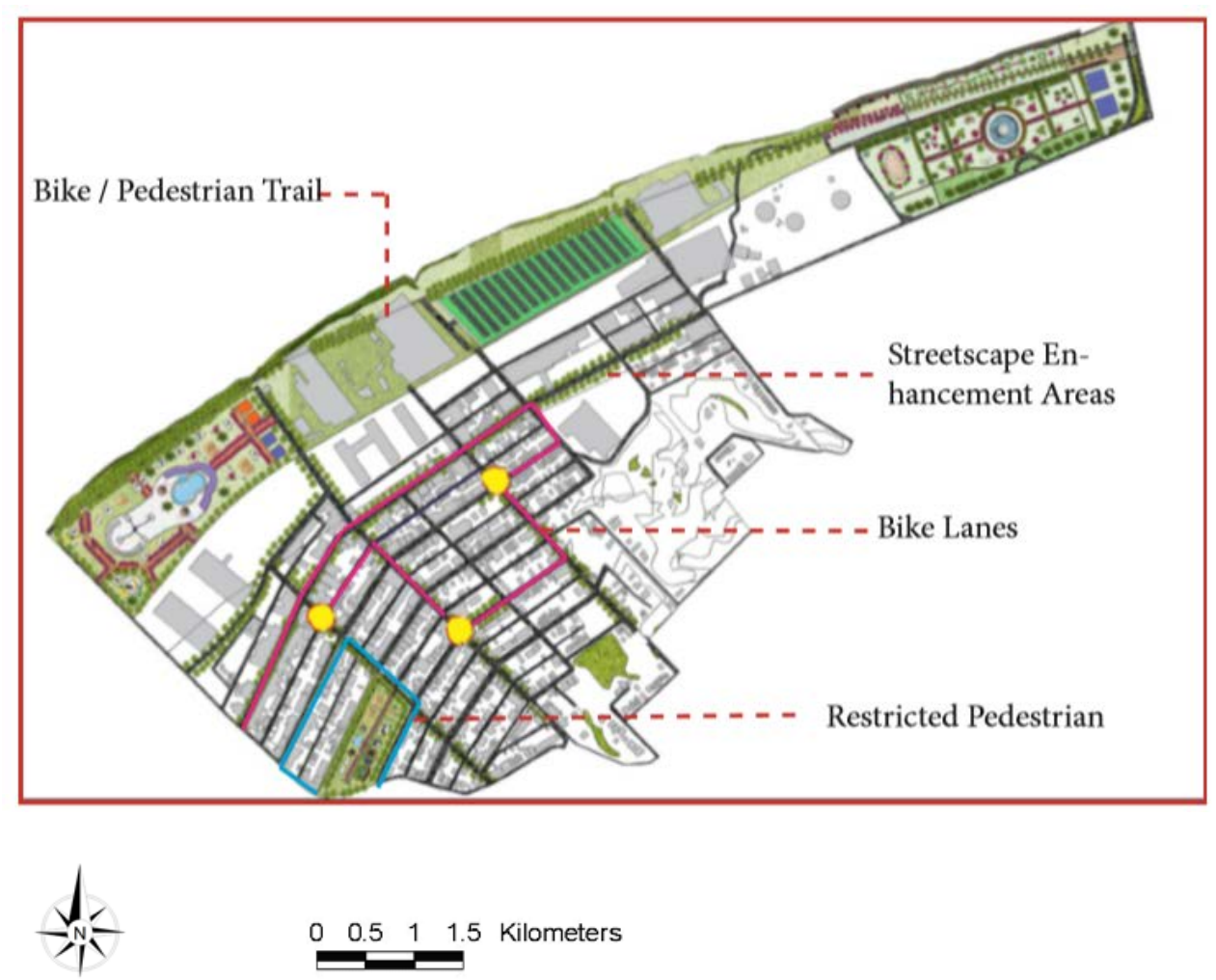

Figure 74: Circulations 
Indoor and lobby movements have taken over the social mix that we get from pedestrian movement. The indoor movement cannot be compared with the outdoor movement because people have a feel of the environment through later means. Because of the comfort (privacy, flexibility) people get from using their cars they tend to use them regardless of the distance of travel. London and Paris have one of the best urban public transportation but still experience low turnout of riders every year. Alexander C. et al., 1977 gave two proposal which they believe will tend towards a healthy environment. Buildings should be layout in a pattern that will form pedestrians' green streets. The bike paths should be designated with a unique color or symbol to create awareness to the road users. Where bike paths are shared with pedestrians there should be a distinction on the path to create a balance. The proposed long trail along the Upper Lawrenceville Park will serve as a bike and pedestrian trail to help boost the number of users of the proposed program and encourage a healthy lifestyle. There a lot of impervious surfaces around the sites; green street will help reduces the impervious surfaces, reduce pollution, and encourage pedestrian and bike circulations. 


\subsection{Perspective Views / Sections}

\section{Perspective Views}
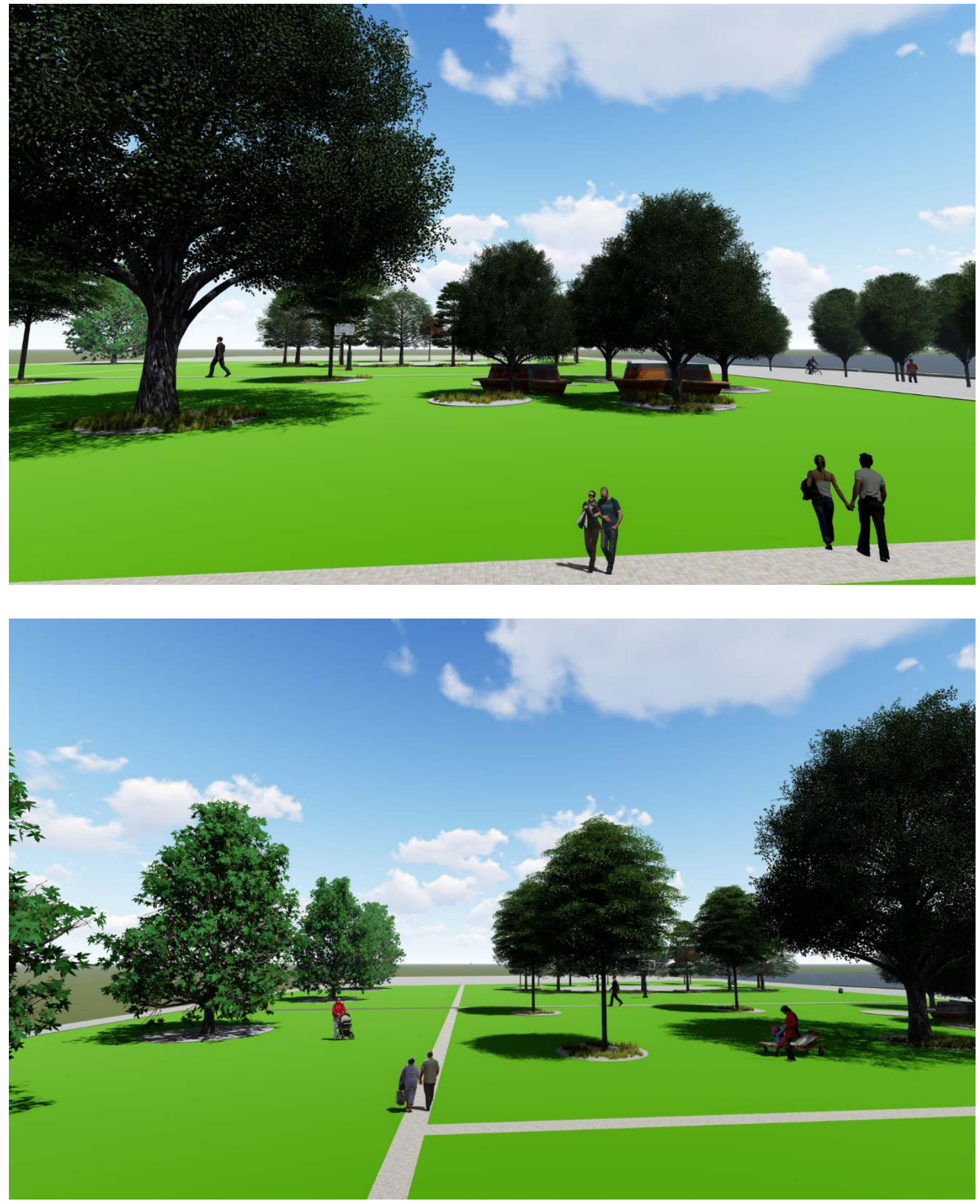

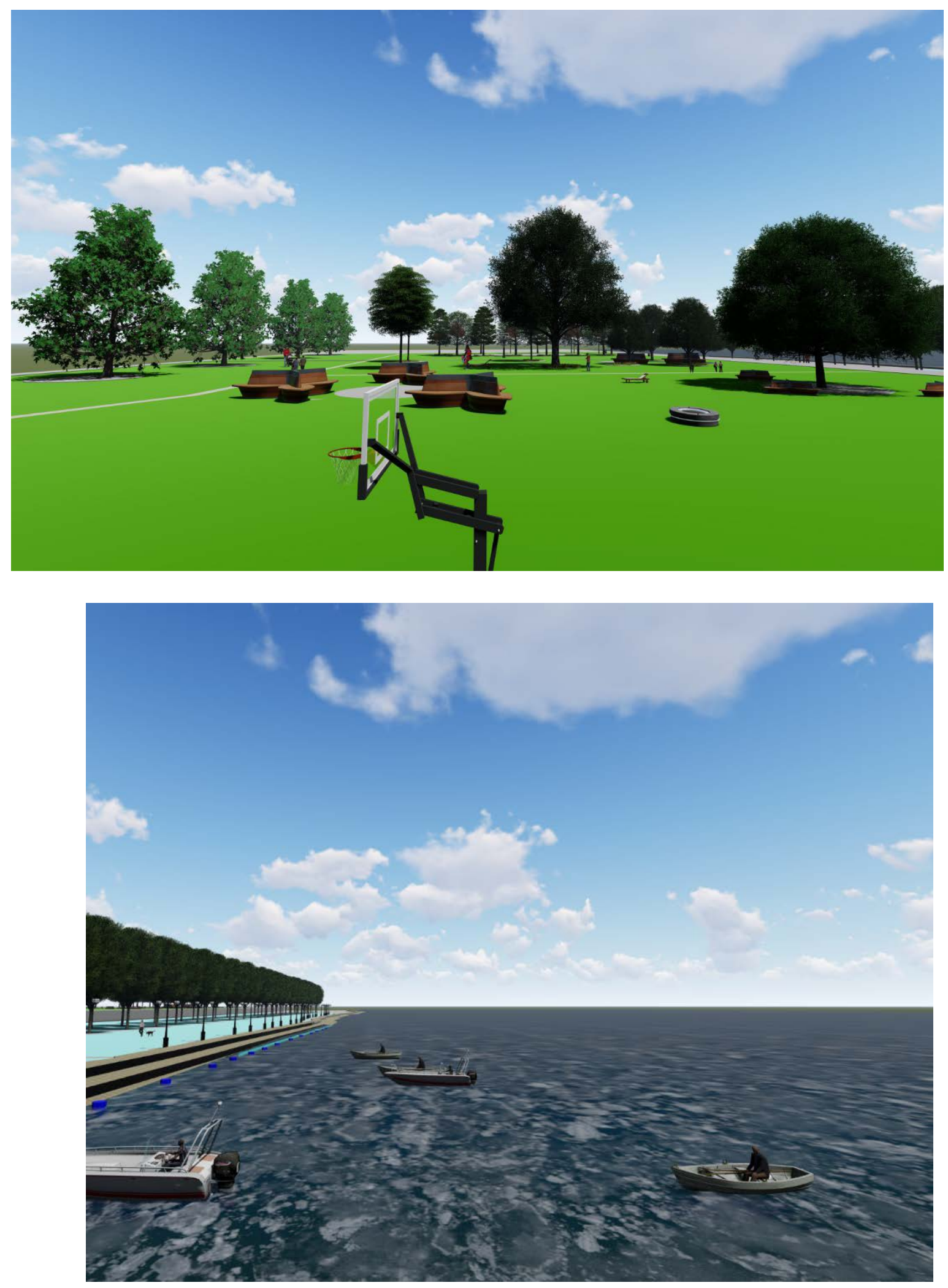

Figure75-78: Perspective views of the outdoor space and Riverfront 


\section{Sectional View}
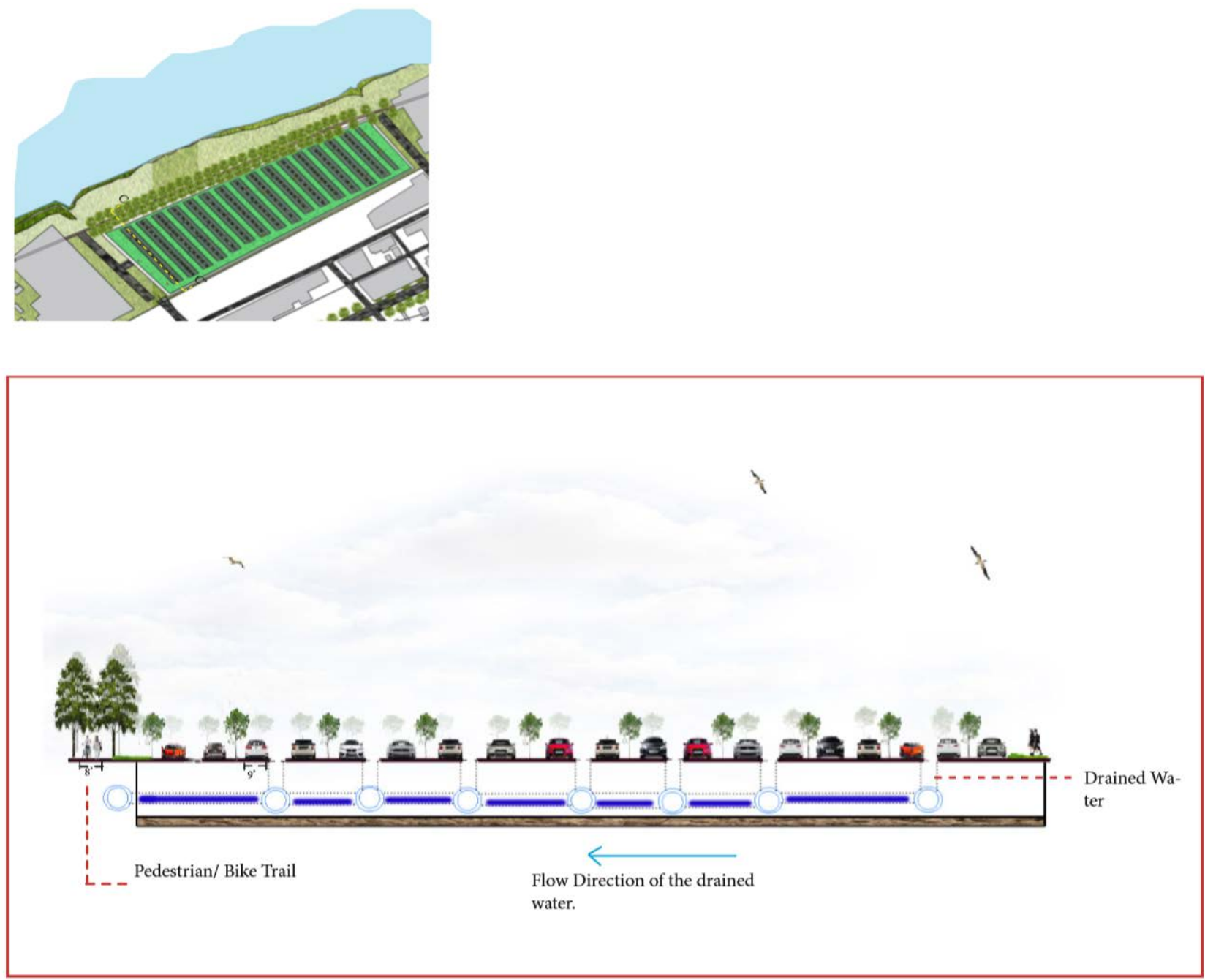

$\begin{array}{lllll}0 & 0.5 & 1 & 1.5 & \text { Kilometers }\end{array}$

Figure79: Green Parking Section 

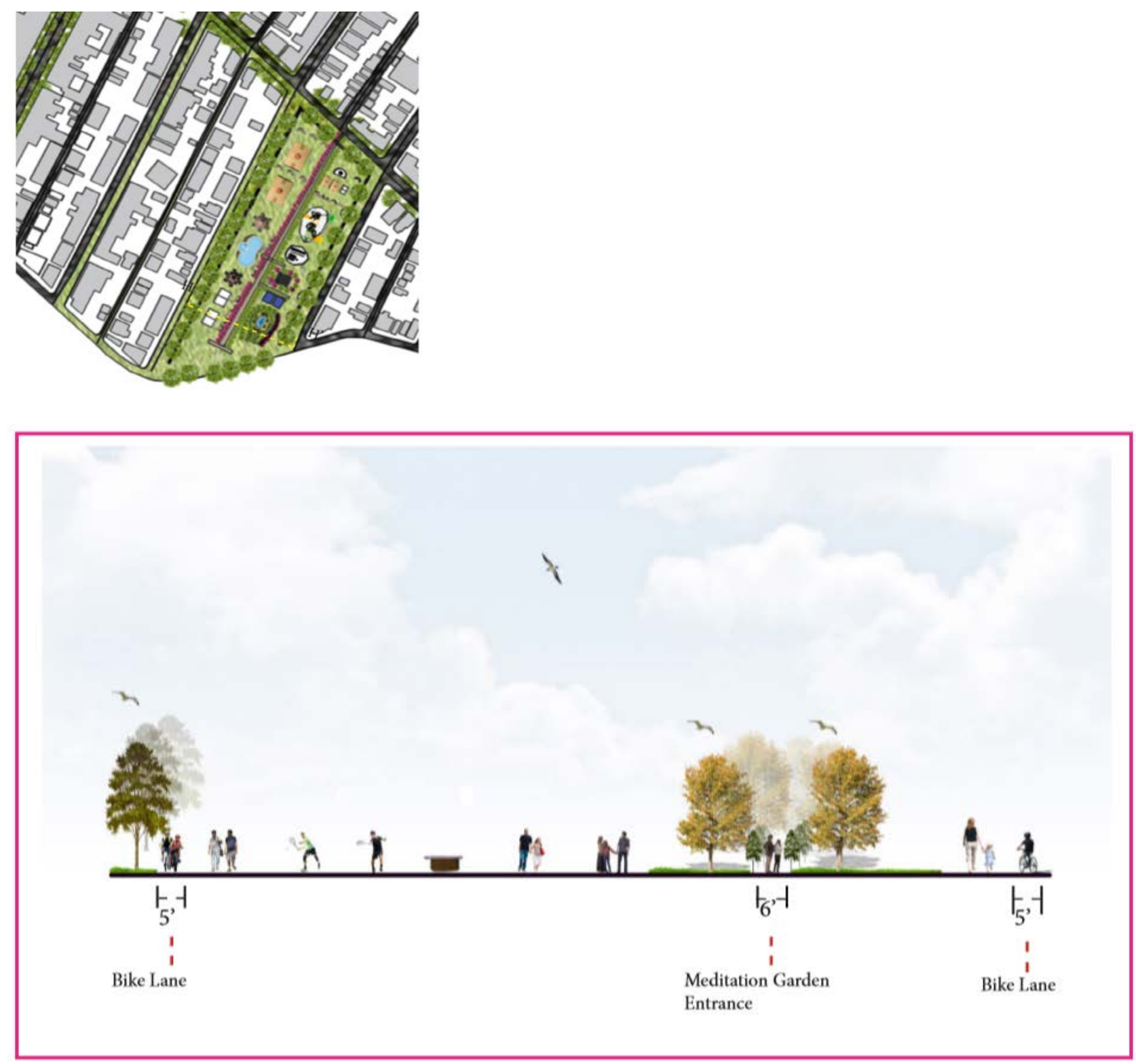

\begin{tabular}{lllll}
0 & 0.5 & 1 & 1.5 & Kilometers \\
\hline
\end{tabular}

Figure 80: The Recreational Park Section 

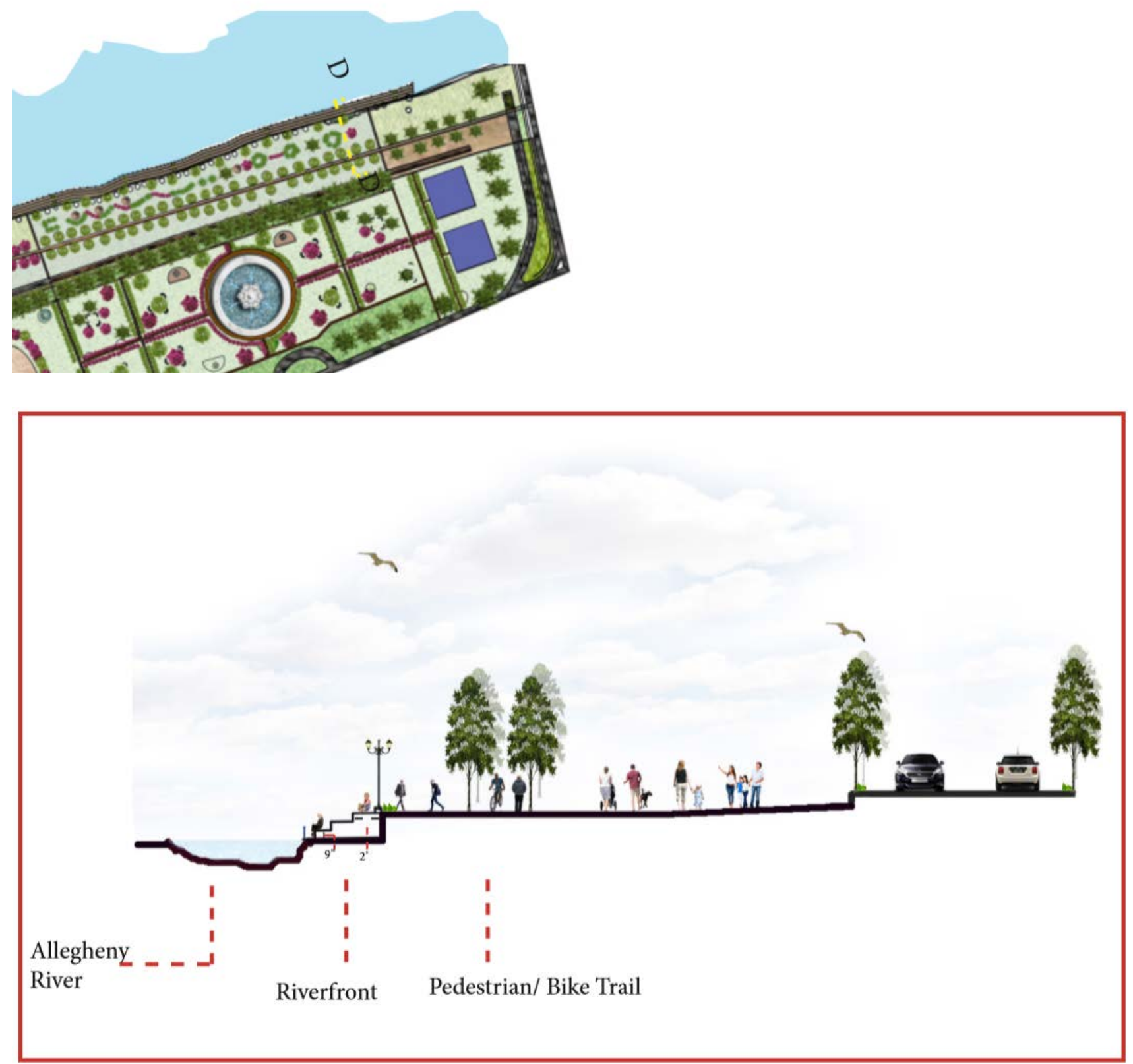

\begin{tabular}{lllll}
0 & 0.5 & 1 & 1.5 & Kilometers \\
\hline
\end{tabular}

Figure 81: The Riverfront Section 

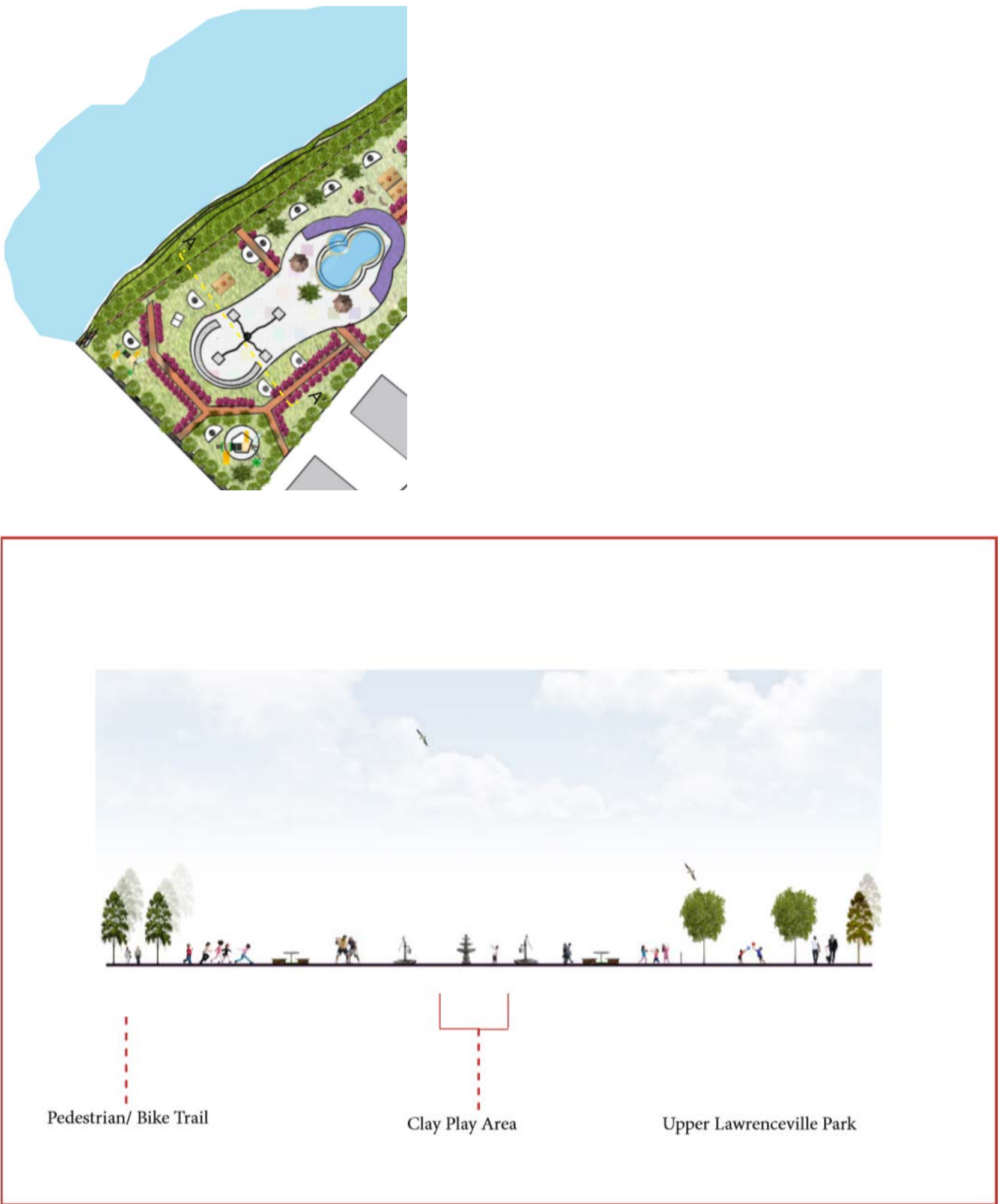

$\begin{array}{lllll}0 & 0.5 & 1 & 1.5 & \text { Kilometers }\end{array}$

Figure 81: Upper Lwarenceville Park Section 


\section{CHAPTER 7}

\section{Disc ussion/ Conclusions}

The results gotten from the first model using the GIS model to access the water quality of the entire Pittsburgh city and the pilot scale site helped me to identify areas with high Total suspended solids which gives one an idea of areas with water quality issue. The result of the i-Tree landscape model showing EPA impaired waters areas have a similarity with the GIS model. It further suggests that there is need for Upper Lawrenceville to take the issue of surface runoff and nonpoint source pollution serious by adapting the interventions proposed and other sustainable practices. The i-Tree Landscape is also instrumental in the analysis of this thesis by guiding me on areas with impervious and canopy areas, air pollution removal, human health risk data, EPA impaired waters area and places to prioritize plantation. The i-Tree Design model majorly helped me to explore how any site location in the USA can maximize the environmental and economic benefits of blue infrastructures and managing surface runoff. The results comparing the 10-year plan benefits of the pre and post conditions of the 5 patterns interventions proposed showed $83 \%$ (3000 trees) increase on the number of trees against $17 \%$ (617 trees) of the existing trees, there is a $99.56 \%(\$ 4,471,350)$ increase of stormwater runoff savings of the post condition against $0.46 \%(\$ 9,771.45)$ of existing condition, $99.6 \%(557,912,963)$ increase in the amount of gallons of rainfall water to be intercepted to $0.04 \%(1,121,253)$ of the existing condition, Air quality improvement savings of $99.6 \%(\$ 863,824)$ of the post condition against $0.04 \%(\$ 1,472.29)$ of the existing condition, and Carbon dioxide reduction savings of $99.2 \%(\$ 229,327)$ of the post condition against $0.08 \%(\$ 880.31)$ of the existing condition. The design programs proposed will help to address the social life of Upper Lawrenceville and encourage sustainability. 


\section{Reference}

admin. (n.d.). Downloads. Retrieved March 8, 2018,from

https://www.tucson.ars.aq.gov/agwa/downloads/

Alexander, C., Ishikawa, S., Silverstein, M., Jacobson, M., Fiksdahl-King, I., \& Shlomo, A. (1977). A pattern language: towns, buildings, construction. New York: Oxford University Press. Retrieved from http://catdir.loc.gov/catdir/enhancements/fy1311/74022874-t.html

Breed, C. A.., ida. breed@up. ac. z., Cilliers, S. S.., sarel. cilliers@nwu. ac. z., \& Fisher, R. C.., roger. fisher@up. ac. z. (2015). Role of Landscape Designers in Promoting a Balanced Approach to Green Infrastructure. Journal of Urban Planning \& Development, 141(3), 1-11. https://doi.org/10.1061/(ASCE)UP.1943-5444.0000248

Browne, F. X. (1978). Nonpoint Sources. Journal (Water Pollution Control Federation), 50(6), 1665-1674. Retrieved from http://www.jstor.org/stable/25040319

Carter, K. B. (1985). Nonpoint Source Pollution: Protecting Our Investment in Clean Water. Journal (Water Pollution Control Federation), 57(2), 104-108. Retrieved from http://www.jstor.org/stable/25042539

Council backs Blue-Green infrastructure plan. (2016). WET News: Water \& Effluent Treatment News, 22(3), 4-4.

Deciduous trees - Minnesota DNR. (n.d.). Retrieved April 23, 2019, from https://www.dnr.state.mn.us/trees shrubs/deciduous/index.html

Development \& Sustainability, 18(2), 373-392. https://doi.org/10.1007/s10668-0159653-y Dusenbury, R., Dunton, S., Minick, S., \& Adamow, M. (2016). Growing Green. Water Environment \& Technology, 28(12), 44-48.

Di Leo, N., Escobedo, F., \& Dubbeling, M. (2016). The role of urban green infrastructure in mitigating land surface temperature in Bobo-Dioulasso, Burkina Faso. Environment,

Dlugonski, A., andrzej_dlugonski@sggw. p., \& Szumanski, M., marek_szumanski@sggw. p. (2015). Analysis of Green Infrastructure in Lodz, Poland. Journal of Urban Planning \& Development, 141(3), 19.

https://doi.org/10.1061/(ASCE)UP.1943-5444.0000242

Dreiseitl, H. (2012). Blue-green infrastructures: water management and infrastructure systems are becoming increasingly important in urban areas. Existing underground systems are reaching their limits. Bishan-Ang Mo Kio Park in Singapore is an example of intergrated infrastructure management in a dense neighbourhood in this Asian metropolis, and includes green, blue, and social infrastructure. Topos: The International Review of Landscape Architecture \& Urban Design, (81), 16-23.

Dreiseitl, H. (2013a). Blue-Green - infrastructure for cities: blue/green, socially grounded, and economically successful - this is what cities all over the world would like 
to be. Liveable citites that support and protect their inhabitants through economic stability but also maintain a healthy environment. Topos: The International Review of Landscape Architecture \& Urban Design, (84), 77-79.

Dreiseitl, H. (2013b). Blue-Green - infrastructure for cities: blue/green, socially grounded, and economically successful - this is what cities all over the world would like to be. Liveable citites that support and protect their inhabitants through economic stability but also maintain a healthy environment. Topos: The International Review of Landscape Architecture \& Urban Design, (84), 77-79.

Green Infrastrucutre in Urban Parks. (2018). BioCycle, 59(1), 6-6. Retrieved from http://search.ebscohost.com/login.aspx?direct=true\&db=aci\&AN=127267238\&site=eh $\underline{\text { ost-live }}$

Home - i-Tree Landscape. (n.d.). Retrieved April 23, 2019, from https://landscape.itreetools.org/

How green infrastructure works. (2016). Crain's Detroit Business, 32(48), 0001. Retrieved from http://search.ebscohost.com/login.aspx?direct=true\&db=f5h\&AN=119695746\&site=eh $\underline{\text { ost-live }}$

https://doi.org/10.1016/j.envsci.2015.07.009

Infrastructure Planning and Management Approach for Urban Sustainability: Case Study of Longgang in China. Journal of Urban Planning \& Development, 141(3), 1-15. https://doi.org/10.1061/(ASCE)UP.1943-5444.0000247

i-Tree Design. (n.d.). Retrieved April 23, 2019, from https://design.itreetools.org/ Joffe, H., Smith, N., \& Anosike, A. E. (2016). City dweller aspirations for cities of the future: how do environmental and personal wellbeing feature? Cities, 59, 102.

Kati, V., \& Jari, N. (2016). Bottom-up thinking-identifying socio-cultural values of ecosystem services in local blue-green infrastructure planning in Helsinki, Finland. Land Use Policy, 50, 537-547.

Liquete, C., Kleeschulte, S., Dige, G., Maes, J., Grizzetti, B., Olah, B., \& Zulian, G. (2015). Mapping green infrastructure based on ecosystem services and ecological networks: A PanEuropean case study. Environmental Science \& Policy, 54, 268-280.

Liu, Y., Meng, Q., Zhang, J., Zhang, L., Jancso, T., \& Vatseva, R. (2016). An effective Building Neighborhood Green Index model for measuring urban green space.

International Journal of Digital Earth, 9(4), 387-409.

https://doi.org/10.1080/17538947.2015.1037870

Lovely, L. (2015). Investing in Green. Water Efficiency, 10(5), 42-47.

MacDonagh, P. (2015). It's Time for Trees. Water Environment \& Technology, 27(7), 32-34. Mathey, J., j. mathey@ioer. d., Rößler, S., s. roessler@ioer. d., Banse, J., j. banse@ioer. d.,Lehmann, I., i. lehmann@ioer. d., \& Bräuer, A., a. braeuer@ioer. d. (2015). 
Mayer-Pinto, M., Johnston, E. I., Bugnot, A. b., Glasby, T. m., Airoldi, L., Mitchell, A., \& Dafforn, K. a. (2017). Building 'blue': An eco-engineering framework for foreshore developments. Journal of Environmental Management, 189, 109-114. https://doi.org/10.1016/j.jenvman.2016.12.039(n.d.).

O'Donnell, E. C., Lamond, J. E., \& Thorne, C. R. (2017). Recognising barriers to implementation of Blue-Green Infrastructure: a Newcastle case study. Urban Water Journal, 14(9), 964-971. https://doi.org/10.1080/1573062X.2017.1279190

O'Hara, K. (2015). Parks, Recreation and Green Infrastructure. Parks \& Recreation, 50(12), 24-25. Retrieved from http://search.ebscohost.com/login.aspx?direct=true\&db=a9h\&AN=111334926\&site=eh $\underline{\text { ost-live }}$

Panagopoulos, T., Jankovska, I., \& Dan, M. B. (2018). Urban Green Infrastructure: The Role of Urban Agriculture in City Resilience. Urbanism. Architecture. Constructions / Urbanism. Arhitectura. Constructii, 9(1), 55-70. Retrieved from http://search.ebscohost.com/login.aspx?direct=true\&db=a9h\&AN=120950107\&site=eh $\underline{\text { ost-live }}$

Pinho, P., 2, ppinho@fc.ul.pt, Correia, O., Lecoq, M., Munzi, S., Vasconcelos, S., 4, Gonçalves, P., ... Branquinho, C. (2016). Evaluating green infrastructure in urban environments using a multi-taxa and functional diversity approach. Environmental Research, 147, 601-610. https://doi.org/10.1016/j.envres.2015.12.025

Qing Chang1, changqing@cau. edu. c., Xiaowen Liu2, xiaowen@cau. edu.c., Jiansheng Wu3, wujs@szpku. edu. c., \& Pan He4, hepanhs@yahoo.com. c. (2015). MSPA-Based Urban Green

Strager M., (2018). RESM 540 Spatial Hydrology Lab Material.

Tamulonis, E. (2016). Green Infrastructure: Making a Virtue of Necessity. Parks \& Recreation, 51(4), 79. Retrieved from http://search.ebscohost.com/login.aspx?direct=true\&db=f5h\&AN=114435484\&site=eh ost-live

Toth, A. (2014). By Improvement of the Green Infrastructure towards Sustainable Landscapes and Resilient Environments. Conference Proceedings of the G20 Youth Forum 2014, (2), 405- 410. 29.Tsegaye, M. S., SHEN Zhongwei, \& Atsebeho, T. E. (2017). The Value of Green Infrastructure in Crafting Sustainability. Journal of Landscape Research, 9(6), 1-6. https://doi.org/10.16785/j.issn1943-989x.2017.6.001

Votsis, A. (2017). Planning for green infrastructure: The spatial effects of parks, forests, and fields on Helsinki's apartment prices. Ecological Economics, 132, 279-289. https://doi.org/10.1016/j.ecolecon.2016.09.029

Vujcic, M., Tomicevic-Dubljevic, J., \& Tomicevic-Gavrilovic, D. (2016). The Socioeconomic and Health Effects of Green Infrastructure on the Vracar Municipality, City of Belgrade. Agriculture \& Forestry / Poljoprivreda i Sumarstvo, 62(3), 165-174. https://doi.org/10.17707/AgricultForest.62.3.14 
Wang, L. K.., \& Wang, M.-H. S. . (2015). Green Infrastructure Implementation. Water Environment \& Technology, 27(9), 115-115.

Wilker, J., Rusche, K., \& Rymsa-Fitschen, C. (2016). Improving Participation in Green Infrastructure Planning. Planning Practice \& Research, 31(3), 229-249.

https://doi.org/10.1080/02697459.2016.1158065

Wolf, K. L. (2017). The Health Benefits of Small Parks and Green Spaces. Parks \& Recreation, 52(4), 28-29. Retrieved from http://search.ebscohost.com/login.aspx?direct=true\&db=a9h\&AN=122333379\&site=eho stlive

Zellner, M., mzellner@uic. ed., Massey, D., dmasse2@uic. ed., Minor, E., eminor@uic. ed., \& Gonzalez-Meler, M., mmeler@uic. ed. (2016). Exploring the effects of green infrastructure placement on neighborhood-level flooding via spatially explicit simulations. Computers, Environment \& Urban Systems, 59, 116-128.

https://doi.org/10.1016/j.compenvurbsys.2016.04.008 